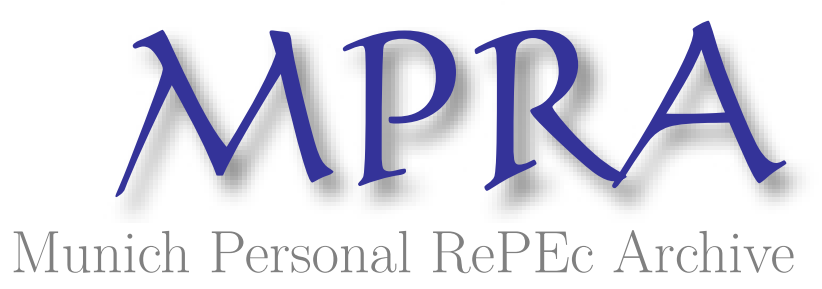

\title{
Private Sector RD in the New Member States: Hungary
}

Havas, Attila

Institute of Economics, HAS

October 2006

Online at https://mpra.ub.uni-muenchen.de/55786/

MPRA Paper No. 55786, posted 08 May 2014 21:10 UTC 


\section{Private Sector R\&D in the New Member States: Hungary}

\section{Attila Havas}

Institute of Economics, HAS

Country Report 


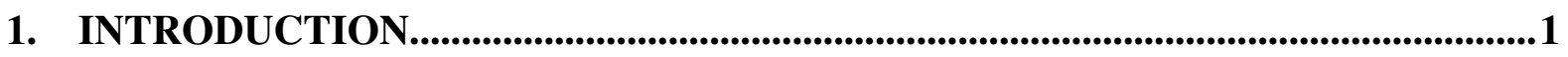

2. NATIONAL LEVEL STI-POLICY .............................................................................

2.1. National STI Policy..................................................................................

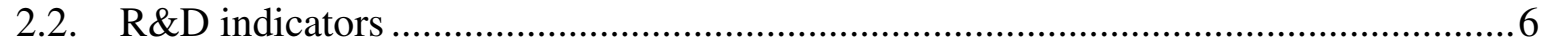

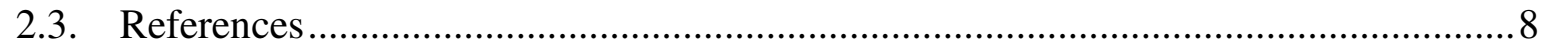

3. SECTOR STUDY: THE HUNGARIAN PHARMACEUTICALS SECTOR..............9

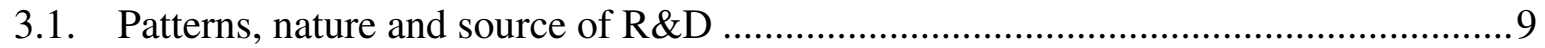

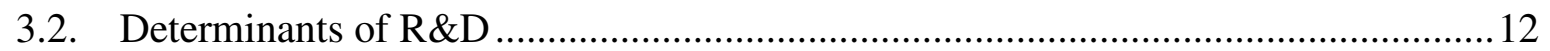

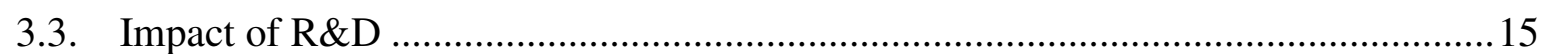

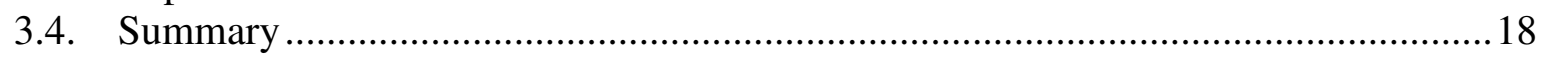

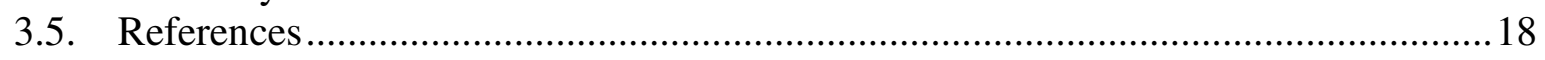

4. SECTOR STUDIES: MANUFACTURE OF ELECTRICAL EQUIPMENT FOR ENGINES AND VEHICLES; MANUFACTURE OF PARTS AND ACCESSORIES FOR MOTOR VEHICLES AND THEIR ENGINES ...........................................................19

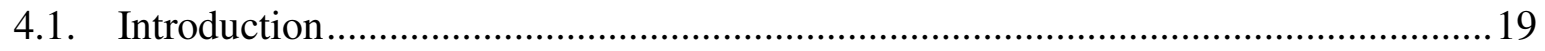

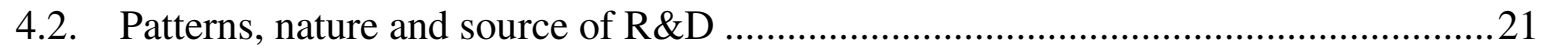

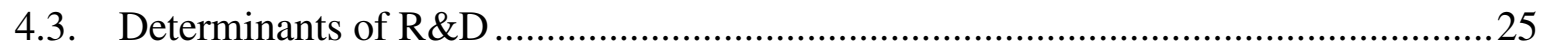

4.3.1. Traditions of the Hungarian Car and Car Components Industries.......................25

4.3.2. Re-emerging Car Production in Hungary …………………………................2.

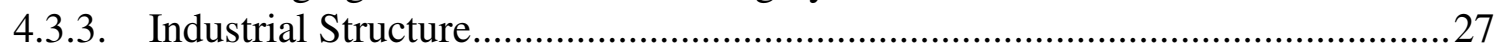

4.3.4. Key Business Players and Ownership Patterns...................................................2

4.3.5. Patterns of Competition .......................................................................................

4.3.6. Production Networks: Sources of innovation ..................................................... 34

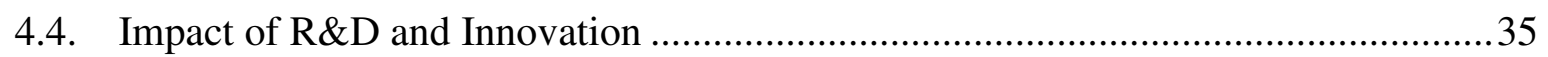

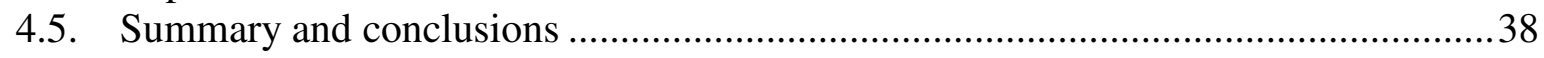

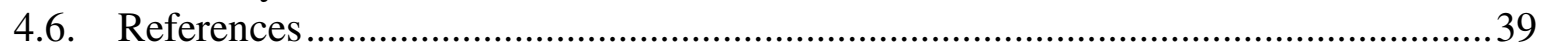

5. SECTOR STUDY: MANUFACTURE OF MEDICAL AND SURGICAL EQUIPMENT AND ORTHOPAEDIC APPLIANCES IN HUNGARY ............................44

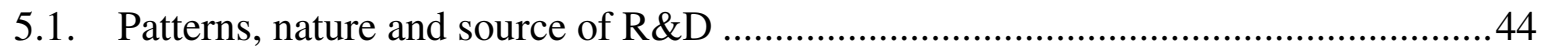

5.2. 2. Determinants of $R \& D$

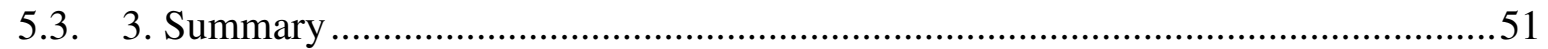

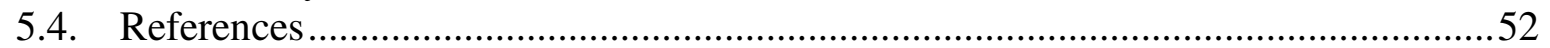

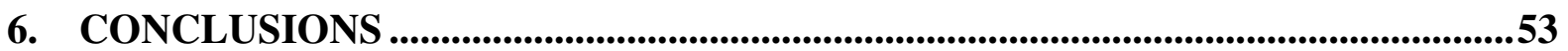

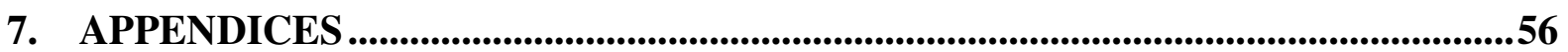




\section{INTRODUCTION}

This report is contributing to an ETEPS project aimed at analysing private sector R\&D activities in the new EU member states. ${ }^{1}$ As a first major task, data availability and reliability have been assessed in Hungary. Then four sectors have been identified for more detailed analyses: two ones with the highest R\&D intensities - excluding ICT sectors -, and further two ones with the fastest growing R\&D intensities.

\section{Data sources}

The main data sources for this type of work are the R\&D and innovation statistics collected by the Hungarian Central Statistical Office. It is a government agency with the mission to provide the society with reliable, impartial and relevant official statistics reflecting the economic, demographic, social and environmental situation of the society and changes occurring therein.

Three main publications are relevant in the context of statistics related to research and development:

- Kutatás és fejlesztés/ Research and Development (annual bilingual publication)

The CSO has been collecting R\&D data since 1969. During this 40 year period, the data collection and publication methods changed according to the specifications of the relevant guidelines, i.e. the Recommendations Concerning the International Standardisation of Science and Technology by the UNESCO from 1978, the Frascati Manual by the OECD from 1996, and its most recent EUROSTAT compatible version from 2002.

- Innováció 1999-2001/Innovation 1999-2001

This specific publication is based on a 2002 survey, which was CIS3 compatible, run on 6,100 companies, covering all sectors of the economy, except for mining and quarrying. The survey considered innovation activities conducted in 1999-2001.

As a preparation for this activity, a pilot innovation survey was conducted in 2000 . That pilot exercise included 1,700 companies from the manufacturing industry.

- Innováció 2003/Innovation 2003

This specific publication is based on a CIS Light survey, conducted in 2004, covering all sectors - except for the construction industries and retail trade, hotels and restaurants, and other community, social and personal service activities -, involving 5,094 companies employing more than 10 employees.

The Hungarian CIS4 survey results are being processed at the time of writing this report, due to be published in September 2006.

A more detailed description of these data sources is available in Appendix 1, while their reliability assessment is presented in Appendix 2.

Due to the crucial intra-sectoral differences among various segments of NACE 2-digit sectors, we have opted for sub-sectors (at NACE 3-digit level) as a unit of analysis. Thus, we

\footnotetext{
1 Framework Service Contract: 150083-2005-02-BE; financed by the European Commission. Research assistance by Bianka Krisztics is gratefully acknowledged.
} 
have also relied on Eurostat data for this country report, when CSO data have not been available at a NACE 3-digit level, e.g. on R\&D employment.

\section{Selection of sectors}

When selecting the sectors for more detailed analyses, we had to face some data constraints: sectoral GDP (value added) data are not available for 2004 as of yet, and thus the 2001-2003 period had to be used here to calculate increase in R\&D intensity. (2004 R\&D data are already available.) The two sectors with the highest R\&D intensities - excluding ICT ones are Manufacture of pharmaceuticals and Manufacture of other electric equipment; ${ }^{2}$ and two sectors with the highest increase in R\&D intensity in recent years are Manufacture of parts and accessories for motor vehicles and their engines and Manufacture of medical instruments. ${ }^{3}$ As Table 1.1 indicates, one sector satisfies both of the two main selection criteria in the same time: Manufacture of other electric equipment has shown a fast growth in terms of its $R \& D$ intensity, and thus, it has achieved a relatively high $R \& D$ intensity - when compared to other Hungarian sectors, i.e. not in absolute terms or in an international comparison - by 2003.

Table 1.1: Selection of sectors for the sectoral studies

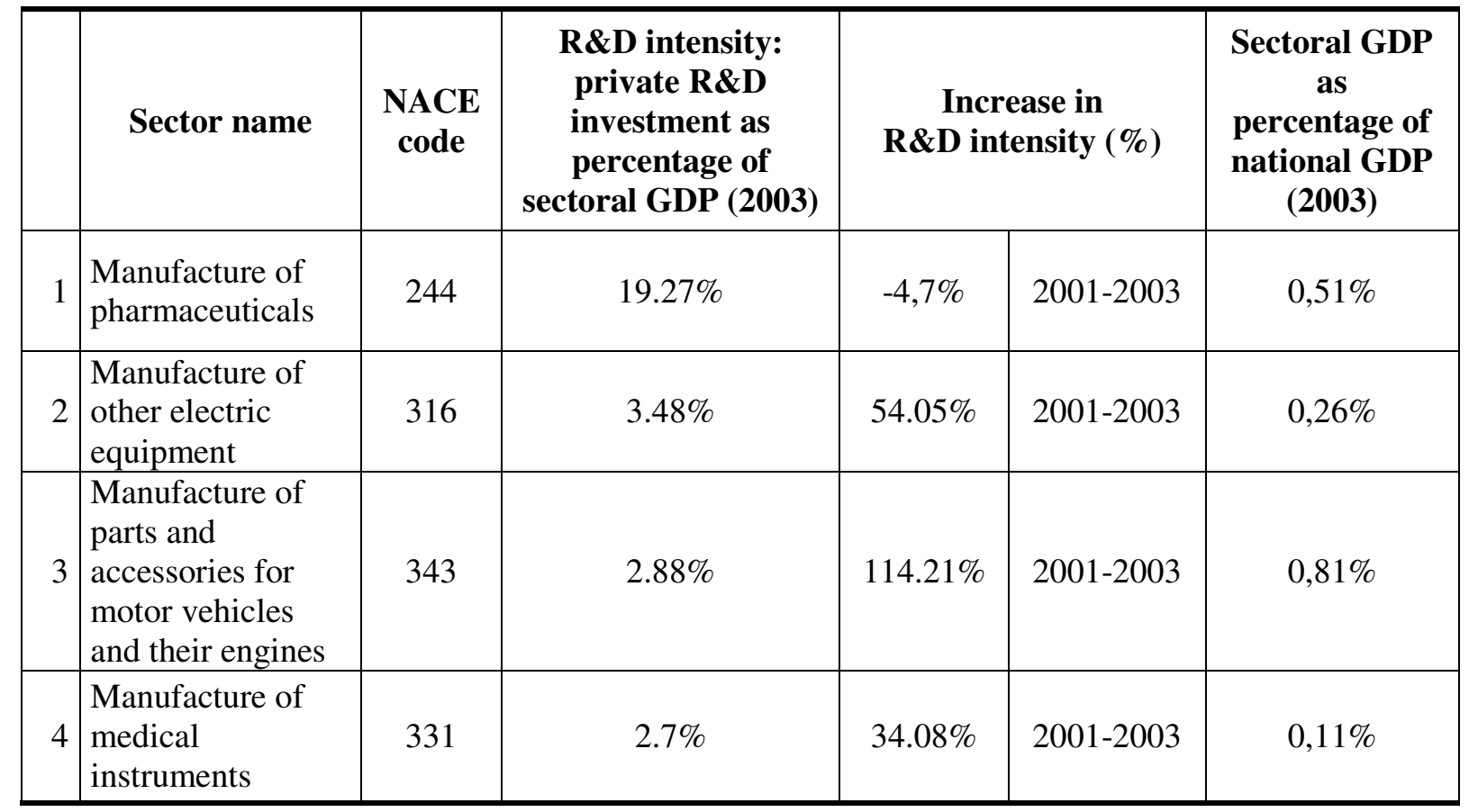

Source: calculation based on CSO data

Section 2 of this country report provides a brief background for the sectoral analyses by summarising the major STI policy challenges at a national level, introducing the current policy tools, and reviewing the most important RTDI indicators. Then Sections 3-5 present the sectoral cases studies: two sectors are closely linked to automotive industry, and thus those two reports are combined into a single section. Section 6 summarises the main findings, and offers conclusions.

\footnotetext{
${ }^{2}$ We have dropped one of the selection criteria, namely a minimum threshold of $2 \%$ for the sectors' contributions to GDP as we have opted for sub-sectors at a NACE 3-digit level.

${ }^{3}$ For the same reason, when selecting these two sectors, we have disregarded the minimum threshold of $1 \%$ of GDP.
} 


\section{NATIONAL LEVEL STI-POLICY}

\subsection{National STI Policy}

The principal challenge for Hungary is to achieve cohesion with the advanced member states of the EU to improve quality of life. The most recent internationally comparable dataset (European Innovation Scoreboard 2005) backs this conclusion by suggesting that there is a gap between Hungary's GDP per capita performance and its innovation performance. Thus, international competitiveness should be enhanced significantly and then maintained for longterm, i.e. it should not - and cannot - merely be based on low production costs. Hungary is already squeezed in a 'nut cracker' formed by advanced countries, on the one hand, and dynamic industrialising countries, on the other. The former are capable of controlling international production networks and markets via new technologies, financial muscles and superior business models, while the latter are characterised by extremely low wages and highly disciplined work forces. It is crucial for Hungary to escape from this trap. That requires the introduction of new products, production processes and services, as well as modern managerial techniques and other types of organisational innovations to raise productivity and find new markets. Macro-economic pressures, notably budget, trade, and balance of payment deficits, also call for a successful, competitive economy. Brain drain, which is harmful both from an economic and a social point of view, can only be reversed, or at least slowed down, by offering attractive conditions for researchers and engineers; i.e. challenging projects, appropriate funds, much better equipment and higher income. Innovation is a must to tackle these issues, but definitely not a panacea: a coherent cohesion strategy is required, composed of appropriate human resource development, health, macroeconomic, investment promotion, regional development and environmental policies just to mention the cornerstones - aligned with each other, as well as with the overall, broad aim of socially, economically and environmentally sustainable and rapid development.

There is already a very high share of foreign-owned companies in Hungary, but they should be better embedded in the domestic economy by improving the performance of the local supplier base, creating attractive conditions for more intense academia-industry relationships, including both local and foreign firms, and thus convincing foreign firms to invest in knowledge-intensive activities in Hungary and offer well-paid jobs by doing so. In sum, a number of elements of the national innovation system (NIS) should be strengthened, and even more importantly, the relationships between them should be intensified. (Hungarian CIS3 data clearly show that the linkages between the innovative companies and other players of NIS are significantly less frequent than those in the EU15 countries.) In brief, a more efficient innovation system could further stimulate future growth.

Regional innovation (and innovation governance) systems are also underdeveloped in Hungary, and a number of modern policy preparation tools (decision-making methods) have been missing both at national and regional levels, or, at best, used only sporadically. The most pertinent examples are regular collection and analysis of RTDI data, foresight programmes, and systematic evaluation of policy tools.

The overall objective of most of the current RTDI policy measures is to improve competitiveness in various ways, i.e. they address the principal challenge faced by Hungary. Table 2.1 provides a comprehensive overview of those RTDI policy measures, which are currently in place, and might have direct or indirect relevance on business RTDI activities. 
Table 2.1: Overview of RTDI policy measures

\begin{tabular}{|c|c|c|c|c|}
\hline Title of measure & Start date & End date & Budget & Number* \\
\hline Technological innovation in supplier networks (INTEG2006) & 2006 & $\mathrm{np}$ & $6.9 \mathrm{~m} €$ & HU 107 \\
\hline "Kozma Laszlo" Prog, to facilitate knowledge transfer & 2006 & $\mathrm{np}$ & $3 m €$ & HU 106 \\
\hline "Baross Gabor" Prog, Supporting regional innov networks & 2006 & $\mathrm{np}$ & $18.6 \mathrm{~m} €$ & HU 105 \\
\hline IPR protection for SMEs abroad & 2006 & $\mathrm{np}$ & $225,564 €$ & HU 103 \\
\hline Establishing a model incubator centre for biotechnology & 2005 & 2007 & $3,8 \mathrm{~m} €$ & HU 100 \\
\hline $\begin{array}{l}\text { "Irinyi Janos" Programme, realisation of individual inventors' } \\
\text { R\&D results and innovative ideas (5LET 2005) }\end{array}$ & 2006 & 2008 & $5,3 \mathrm{~m} €$ & HU 99 \\
\hline Setting up a Nanotechnology Research Laboratory & 2006 & 2009 & $7.2 \mathrm{~m} €$ & HU 98 \\
\hline "Asboth Oszkar" Prog for Cutting-edge Industries, 2005 & 2005 & 2009 & $26 m €$ & HU 97 \\
\hline INNOCSEKK (Innovation voucher) & 2005 & 2007 & $20 \mathrm{~m} €$ & HU 96 \\
\hline Law on Research and Technological Innovation & 2005 & $\mathrm{np}$ & na & HU 95 \\
\hline Large international R\&D projects & 2005 & 2007 & $9.6 \mathrm{~m} €$ & HU 94 \\
\hline Regional Innovation Agencies & 2005 & 2007 & $5.6 \mathrm{~m} €$ & HU 93 \\
\hline Mobile Communications R\&D and Innovation Centre & 2005 & 2008 & $8 \mathrm{~m} €$ & HU 92 \\
\hline Co-operative Research Centres (KKK II) & 2005 & $\mathrm{np}$ & $8 \mathrm{~m} €$ & HU 91 \\
\hline Information infrastructure for R\&D & 2005 & $\mathrm{np}$ & $5.6 \mathrm{~m} €$ & HU 90 \\
\hline Innovative Education Support Systems & 2005 & $\mathrm{np}$ & $1.6 \mathrm{~m} €$ & HU 89 \\
\hline Miksa Deri (EUREKA) & 2005 & 2010 & $2 \mathrm{~m} €$ & HU 88 \\
\hline $\begin{array}{l}\text { "Pazmany Peter" Prog (Regional Knowledge Centres at } \\
\text { Universities) }\end{array}$ & 2005 & 2008 & $36 m €$ & HU 87 \\
\hline Research and Technological Innovation Fund & 2004 & $\mathrm{np}$ & na & HU 86 \\
\hline Employment of PhD, MSc or MBA students & 2004 & $\mathrm{np}$ & & HU 85 \\
\hline $200 \%$ of R\&D expenditures deductible & 2001 & $\mathrm{np}$ & & HU 84 \\
\hline Developing the infrastructure of education and training & 2004 & 2006 & $98.8 \mathrm{~m} €$ & HU 83 \\
\hline Promoting life-long learning and adaptability & 2004 & 2006 & & HU 82 \\
\hline Agri-food RTDI projects & 2004 & $\mathrm{np}$ & $12 m €$ & HU 74 \\
\hline Innovation and research activities of SMEs & 2004 & 2006 & $1.6 \mathrm{~m} €$ & HU 73 \\
\hline $\begin{array}{l}\text { Development of corporate research infrastructure related to } \\
\text { the creation of new RTD jobs }\end{array}$ & 2004 & 2006 & $3.2 \mathrm{~m}$ & HU 69 \\
\hline $\begin{array}{l}\text { Support to new, technology and knowledge-intensive micro- } \\
\text { enterprises and spin-off companies (GVOP 3.3.1) }\end{array}$ & 2004 & 2006 & $3.2 \mathrm{~m} €$ & HU 58 \\
\hline $\begin{array}{l}\text { S\&T co-operation of businesses and publicly financed research } \\
\text { units (CRC, GVOP } 3.2 .2 \text { ) }\end{array}$ & 2004 & 2006 & $12 m €$ & HU 55 \\
\hline $\begin{array}{l}\text { Development of the research infrastructure of publicly financed } \\
\text { and non-profit research facilities }\end{array}$ & 2004 & 2006 & $12 \mathrm{~m} €$ & HU 51 \\
\hline "Jedlik Anyos" Programme & 2000 & $\mathrm{np}$ & $44 m €$ & HU 24 \\
\hline Participation of SMEs in EU 6th Framework Programme & 2003 & 2007 & & HU 22 \\
\hline Social conditions of technological development & 1991 & $\mathrm{np}$ & & HU 13 \\
\hline $\begin{array}{l}\text { Regional information and consultancy services on EU 6th } \\
\text { Framework Programme }\end{array}$ & 2003 & 2007 & & $\mathrm{HU} 6$ \\
\hline Application-oriented co-operative RTD activity & 2004 & 2006 & $28 \mathrm{~m} €$ & $\mathrm{HU} 1$ \\
\hline
\end{tabular}

Source: European TrendChart on Innovation database; * number of a given policy measure in that database Notes: $\mathrm{np}=$ no end date planned; $\mathrm{na}=$ Not applicable

Two of the above measures are of direct relevance for the sectors analysed in this report. Both of them are recent ones, however, and thus it would be too early to assess their impacts on business R\&D activities.

One of them, called Technological innovation in supplier networks (INTEG2006) aims to enhance the innovation capabilities of SMEs in order to prepare them to establish long-term 
supplier relationships with medium-sized or large enterprises (the so-called integrators). The main tool to promote these strategic partnerships is co-operation in innovation projects in four sectors: machinery, automotive, electronics, and precision engineering industries.

The overall aims of the measure are to:

- increase the share of indigenous suppliers in the supplier networks of medium-sized and large enterprises;

- decrease the dependence of indigenous suppliers;

- provide motivation for the "integrator" companies to increase the number of indigenous suppliers;

- improve co-operation between integrators and suppliers in the field of technological innovation;

- promote the growth of SMEs.

The specified industries are among the best performing sectors of the Hungarian economy with respect to production and exports. Typically, they are also characterised by dominant foreign ownership and the use of multinational supplier networks. The measure aims to facilitate higher Hungarian participation in these industries and increase the potential for learning and upgrading for indigenous SMEs. In the first phase of the projects, the mediumsized and large size companies must select SMEs that wish to become their suppliers, identify the aims of the project, and co-operate in product and process innovation tasks. The partners should develop a medium-term business plan, explaining how the project's results would be exploited by the suppliers and the integrator. The integrators should monitor the progress of innovation activities of the selected partners, who should co-operate with each other. The integrators must also provide a statement that upon the completion of the project, they shall audit the participating SMEs, and in case of a successful audit, issue a supplier certificate.

The other one is called Establishing a model incubator centre for biotechnology (BIOINKUB). This measure provides support for investments, which aim to create incubator centres for small- or medium-sized enterprises in the field of biotechnology. The centres shall be able to operate independently; they must offer favourable conditions for the R\&D activities of the hosted enterprises aimed at developing new products, processes and services, and promote their growth. The project consists of two phases. In the first phase, the applicant develops the specified infrastructure using the funds provided by the measure and finishes the investment project within two years. In the second phase, the applicant is obliged to operate the incubator centre according to the original terms defined in the call for five years. The centre must provide services that assist entrepreneurship and innovation activities in the hosted companies.

Other measures, not aimed at supporting specific sectors or technologies, might be also relevant for pharmaceuticals, automotive or medical instruments companies, e.g. the ones offering tax incentives for $\mathrm{R} \& \mathrm{D}$, as well as those promoting applied research and the introduction of new products or production processes; academia-industry co-operation; the improvement of innovation capabilities of SMEs; start-up and spin-off companies; modernisation and/ or extension of corporate R\&D infrastructure; international RTDI cooperation.

There are no readily available studies to assess the impacts of these other - "generic" measures on the four sub-sectors analysed in Sections 3-5. 


\subsection{R\&D INDICATORS}

Hungary's innovation performance is lagging considerably behind the EU25 average. On the input side, the most worrisome feature is the very low spending of businesses on R\&D: $0.33 \%$ of GDP (in 2004), which is less than one third of the EU25 average. Hungarian R\&D expenditures are way below the Lisbon (Barcelona) targets, and public R\&D expenditures have been shrinking. (Table 2.2; Figure 2.1) Given the macroeconomic pressures to comply with the Maastricht criteria, a pre-requisite to join the euro zone, it is questionable that the country would make any significant progress in this respect in the coming years.

Table 2.1: GERD/GDP (per cent)

\begin{tabular}{lrrrrrr}
\hline & 2000 & 2001 & 2002 & 2003 & 2004 & 2005 \\
\hline GERD/GDP & 0.82 & 0.94 & 1.01 & 0.95 & 0.89 & 0.95 \\
\hline
\end{tabular}

Source: Central Statistical Office

Figure 2.1: Composition of GERD by funding sources (current bn HUF)

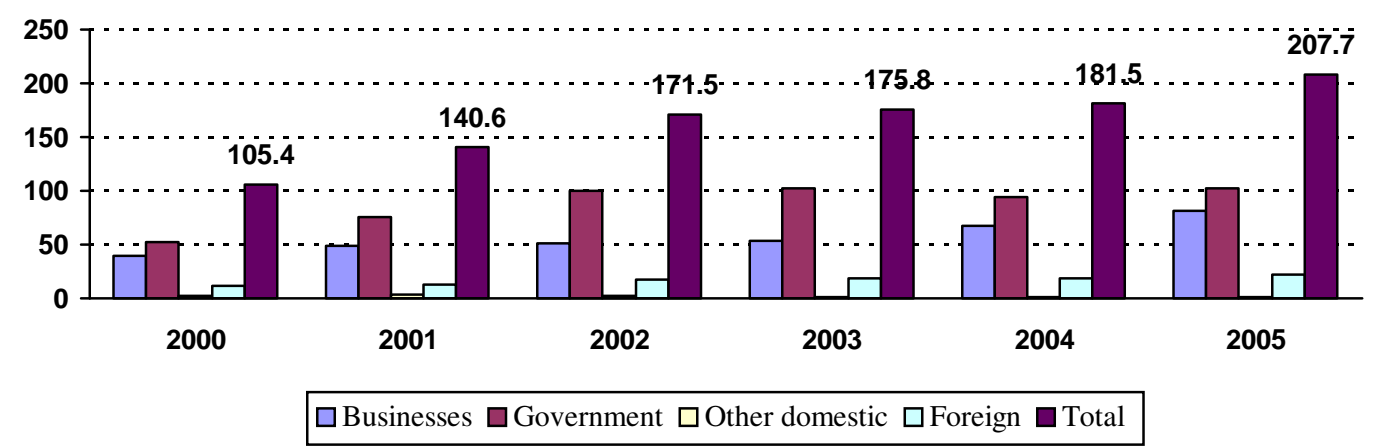

Source: Central Statistical Office

The number of R\&D units operated by business enterprises has increased considerably by 2005 , but from a very low level, if one takes into account the number of enterprises (several hundreds of thousands). The growth of research scientists and engineers employed by enterprises has been modest until 2004, and then quite remarkable in 2005: 16.2\%. (Table 2.2)

Table 2.2: Number of R\&D units and R\&D employment (FTE) by sector

\begin{tabular}{lrrrrrr}
\hline & $\mathbf{2 0 0 0}$ & $\mathbf{2 0 0 1}$ & $\mathbf{2 0 0 2}$ & $\mathbf{2 0 0 3}$ & $\mathbf{2 0 0 4}$ & $\mathbf{2 0 0 5}$ \\
\hline R\&D institutes and other research units & 121 & 133 & 143 & 168 & 175 & 201 \\
$\quad$ Scientists and engineers & 4,653 & 4,657 & 4,622 & 4,741 & 4,693 & 4,959 \\
R\&D units at higher education & 1,421 & 1,574 & 1,613 & 1,628 & 1,697 & 1,566 \\
institutes & & & & & & \\
$\quad$ Scientists and engineers & 5,852 & 5,938 & 5,999 & 5,957 & 5,902 & 5,911 \\
R\&D units of business enterprises & 478 & 630 & 670 & 674 & 669 & 749 \\
$\quad$ Scientists and engineers & 3,901 & 4,071 & 4,344 & 4,482 & 4,309 & 5,008 \\
\hline R\&D units; total & $\mathbf{2 , 0 2 0}$ & $\mathbf{2 , 3 3 7}$ & $\mathbf{2 , 4 2 6}$ & $\mathbf{2 , 4 7 0}$ & $\mathbf{2 , 5 4 1}$ & $\mathbf{2 , 5 1 6}$ \\
\hline Scientists and engineers; total & $\mathbf{1 4 , 4 0 6}$ & $\mathbf{1 4 , 6 6 6}$ & $\mathbf{1 4 , 9 6 5}$ & $\mathbf{1 5 , 1 8 0}$ & $\mathbf{1 4 , 9 0 4}$ & $\mathbf{1 5 , 8 7 8}$ \\
\hline
\end{tabular}

Source: Research and Development, Central Statistical Office, various years 
The most recent available survey results suggest that only $28.8 \%$ of Hungarian manufacturing firms are innovative (the Hungarian CIS3 survey, covering the period of 1999-2001), compared to $47 \%$ in the EU industry (CIS3, 1998-2000) Neither important innovation input data, e.g. innovation expenditures, nor innovation output data, such as the share of new products in sales or export revenues, and effects of innovations, are published in Hungary.

There is a significant gap in terms of human resources for $R \& D$ and innovation: the ratio of science and engineering graduates among people aged between 20 and 29 was $4.8 \%$, which leaves Hungary in $21^{\text {st }}$ position in the EU25. Yet, the low share of S\&E graduates might be regarded as a rational reaction if it is seen in its wider historical perspective. R\&D personnel had been cut drastically up until 1995 , by 56.5 percent compared to $1988 .{ }^{4}$ Since then, a slight increase can be observed. Yet, the 2005 total was still $48.4 \%$ lower than the 1988 one, while for scientists and engineers the gap is $25.9 \%$.(Figure 3) Moreover, the number of university personnel is still being cut, in spite of the 'exploding' number of students. ${ }^{5}$ Against this background, it is quite understandable that young talents opt for other career paths.

\section{Figure 3: R\&D personnel in Hungary, 1988-2005, full-time equivalent}

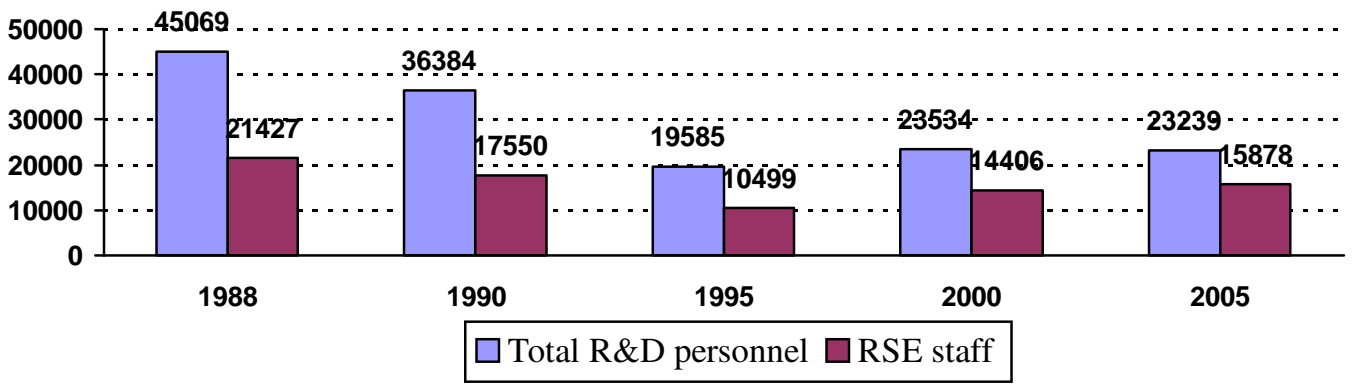

Source: Central Statistical Office

Another important indicator on human resources for innovations, namely the share of working age population with tertiary education shows a considerably smaller gap: $16.7 \%$ (HU) vs. 21.9\% (EU25) in 2004. A further warning is signalled, however, by the low participation in life-long learning: 4.6\% (HU) of the population aged 24-65 years, as opposed to $9.9 \%$ (EU25) in $2004 .^{6}$

An apparently very good Hungarian performance is suggested by four indicators: employment in high-tech manufacturing and services was $125 \%$ and $98 \%$ of the EU25 average, respectively (in 2003), while the ratio of high-tech products in total exports was $122 \%$ of the EU25 average (2003), and the share of value added stemming from high-tech manufacturing stood at 126 percent of the EU25 average (in 2002). Yet, a number of factors should be considered when appraising these figures from a policy point of view. First, one should keep in mind the very high share of FDI in Hungarian manufacturing, coupled with the weight of foreign-owned firms active in sectors that are classified as high-tech ones by the OECD, given their R\&D intensity. Second, although these sectors are regarded as "engines of growth", a

\footnotetext{
${ }^{4}$ The first few years of the transition process, i.e. 1990-92, were especially harsh in this respect.

${ }^{5}$ For an overview of planned redundancies at a number of universities and colleges, see, e.g. Népszabadság, 19 February 2005.

${ }^{6}$ It should be added, however, that there is no unequivocally accepted indicator that could provide us with meaningful and comparable measurement of this phenomenon.
} 
number of recent theoretical and empirical analyses refute this widely held, uncritically accepted view. (Hirsch-Kreinsen et al. [2005]; Sandven et al. [2005]; Smith [2002], [2003]; von Tunzelmann and Acha [2004]) Third, R\&D-intensive industries (or services), as classified by the OECD, are not necessarily R\&D-intensive ones in all countries. In fact, $R \& D$ intensities of the so-called ICT high-tech industries were way below the OECD high-tech threshold in 1995-2000 in a large number of OECD member states, including all the four Central European member states, as well as Denmark, Italy, Korea, Mexico, Portugal and Spain. What is even more striking, the R\&D intensity of the high-tech ICT sectors was below the average $R \& D$ intensity of manufacturing industry in the four Central European countries. (Srholec [2006]) Thus, it would be a gross mistake to regard these sectors as 'technology leaders' - with all the assumed positive impacts on growth and competitiveness - in these countries.

Further RTDI indicators - national and sectoral ones - are reproduced in Appendices 3-13.

\subsection{REFERENCES}

EIS [2005]: European Innovation Scoreboard, http://trendchart.cordis.lu/scoreboards/scoreboard2005/index.cfm

European Trend Chart on Innovation [2005]: Annual Innovation Policy Trends and Appraisal Report Hungary, 2004 - 2005, http://trendchart.cordis.lu

Eurostat [2004]: Innovation in Europe: Results for the EU, Iceland and Norway, Luxembourg: Office for Official Publications of the European Communities

Hirsch-Kreinsen H. et al. (eds) [2005]: Low-tech Innovation in the Knowledge Economy, P. Lane

KSH [2003]: Innováció 1999-2001/Innovation 1999-2001, Budapest: Központi Statisztikai Hivatal (Central Statistical Office)

KSH [2004]: Kutatás és fejlesztés/ Research and Development, Budapest: Központi Statisztikai Hivatal (Central Statistical Office)

Sandven T., Smith K., Kaloudis A. [2005]: Structural change, growth and innovation: the roles of medium and low tech industries, 1980-2000, in: Hirsch-Kreinsen H. et al. (eds) Low-tech Innovation in the Knowledge Economy, P. Lane

Smith K. [2002]: What is the 'Knowledge Economy'? Knowledge intensity and distributed knowledge bases, UNU/INTECH Discussion Paper Series, 2002-6 (Available at: http://www.intech.unu.edu/publications/discussion-papers/2002-6.pdf)

Smith K. [2003]: Innovation, Growth and Employment in Europe: the Role of Low-tech Industries, paper presented at the conference on Policy and Innovation in Low-tech, University of Dortmund, February 14, 2003

von Tunzelmann N., Acha V. [2004]: “Innovation in 'Low-Tech' Industries” In Fagerberg J., Mowery D. C., Nelson R. R. (Eds) The Oxford Handbook of Innovation, Oxford: Oxford UP 


\section{SECTOR STUDY: THE HUNGARIAN PHARMACEUTICALS SECTOR}

\subsection{Patterns, NATURE AND SOURCE OF R\&D}

The chemical industry has been one of the best performing industries considering its overall performance and the specified research and development indicators since the transition of the Hungarian economy started. Although the whole chemical industry is characterised by dynamic development and high R\&D potential, the sub-divisions of the industry show significant differences regarding the importance of $R \& D$ and the use and availability of $R \& D$ resources. This report, therefore, relies on sub-division (NACE 3) level data for the manufacture of pharmaceuticals, medicinal chemicals and botanical products wherever it is available.

The difference between the performances of the pharmaceutical and the chemical industry is also apparent at the EU25 level, where the production volumes of these industries rose by 2.7 and 2.5 percent, respectively in 2004 , by 3.7 and 1.9 percent in 2005 and are expected to grow by 3.8 and 2.3 percent in 2006 (CEFIC, 2005). This means that in the past few years the pharmaceutical industry grew significantly faster than the complete chemical industry. Hungary's contribution to the production of chemicals on the EU25 level is not substantial. In 2002 , the value added produced by the Hungarian chemical industry amounted to $1,191 \mathrm{~m}$ euro, which is less than 1 percent of the total EU25 production. The Hungarian chemical industry employed 35,000 employees, (1.8 percent of the EU25 employment) at 14,300 euro cost per head. In 2004, Hungary claimed 0.7 percent of the EU25 chemical industry, which amounted to 586bn euro. (Eurostat, 2005)

The share of pharmaceuticals in the national GDP has grown to $0.5 \%$ by 2003 , thanks to a healthy growth in its production value (from $840 \mathrm{~m}$ euro in 1999 to $1537 \mathrm{~m}$ euro in 2003).

The private R\&D expenditures in NACE 24.4 amounted to 82.6 m euro in 2004 , up from 43.7 $m$ euro in 1998. The share of $R \& D$ expenditures of pharmaceuticals industry in the total BERD is close to $28 \%$, that is, exceeds $34 \%$ of the private $R \& D$ expenditures in the manufacturing industry.

The number of researchers has been fluctuating around 1600-1700 since 1998. The total number of researchers was 1771 (head counts) in 2004, which represents around $20 \%$ of the total number of researchers in the private sector.

The manufacture of pharmaceuticals, medicinal chemicals and botanical products proved to be the most R\&D intensive industry in Hungary concerning the specified indicators. In 2003, the ratio of R\&D expenditure to the GDP and sales revenue of the sector amounted to $19.27 \%$ and $11.38 \%$ respectively. This is by far the highest R\&D intensity value with respect to both indicators among all the sectors of the Hungarian manufacturing industry. Between 2001 and 2003 , R\&D expenditure in the pharmaceuticals industry increased by 20 percent/year on average and R\&D intensity averaged around 11 and 20 percent in terms of the sales revenue and sectoral GDP. The second indicator shows a slight decrease in the R\&D intensity of the sector since its value was even higher in 2001 than in 2003. The weight of the 3-digit sector in the national GDP is 0.507 percent, while it claims about 2.5 percent of the industrial output. 
Table 3.1 presents those production indicators for which time series are available in the pharmaceuticals industry. The data suggests that the manufacture of pharmaceuticals is one of the biggest contributors to the production and employment in the Hungarian chemical industry. In 1998, the pharmaceuticals industry claimed more than 50 per cent of the value added and the gross operating surplus of the chemical industry.

Table 3.1: Overview of the Hungarian pharmaceuticals and chemicals industry, 1998

\begin{tabular}{|l|c|c|}
\hline & $\begin{array}{c}\text { Manufacture of } \\
\text { pharmaceuticals, } \\
\text { medicinal chemicals } \\
\text { and botanical } \\
\text { products }\end{array}$ & $\begin{array}{c}\text { Manufacture of } \\
\text { chemicals and } \\
\text { chemical products }\end{array}$ \\
\hline Number of persons employed (1000) & 16.0 & 39.6 \\
\hline Sales (m euro) & 857.5 & 2264.8 \\
\hline Value added (m euro) & 394.8 & 792 \\
\hline Gross operating surplus (m euro) & 231.6 & 467.4 \\
\hline Personnel costs (m euro) & 163.2 & 324.6 \\
\hline Labour productivity (1000 euro/head) & 24.8 & 20 \\
\hline Unit personnel costs (1000 euro/head) & 10.3 & 8.2 \\
\hline Social security costs/total personnel costs & 26.6 & 27 \\
\hline
\end{tabular}

Source: Eurostat

Data on the evolution of production and sales volumes is also available.

Table 3.2: Evolution of the Hungarian pharmaceuticals industry, 2003-2005

\begin{tabular}{|l|c|c|c|}
\hline Percentage change* in volume of & 2003 & 2004 & 2005 \\
\hline Gross output & 121.8 & 108.1 & 99.9 \\
\hline Total sales & 115.5 & 110.6 & 95.7 \\
\hline Domestic & 95.0 & 97.3 & 98.5 \\
\hline Export & 125.8 & 118 & 160.6 \\
\hline
\end{tabular}

$*$ previous year $=100 \%$

Source: author's calculation based on CSO data

Figure 3.1 shows the evolution of sales revenues of the Hungarian pharmaceuticals market between 1997 and 2004. While the number of boxes consumed remained fairly stable, the value of sales has continuously increased during the period. In 2004, sales of pharmaceuticals exceeded 480 bn HUF. 
Figure 3.1: The Hungarian pharmaceuticals market, 1997-2004

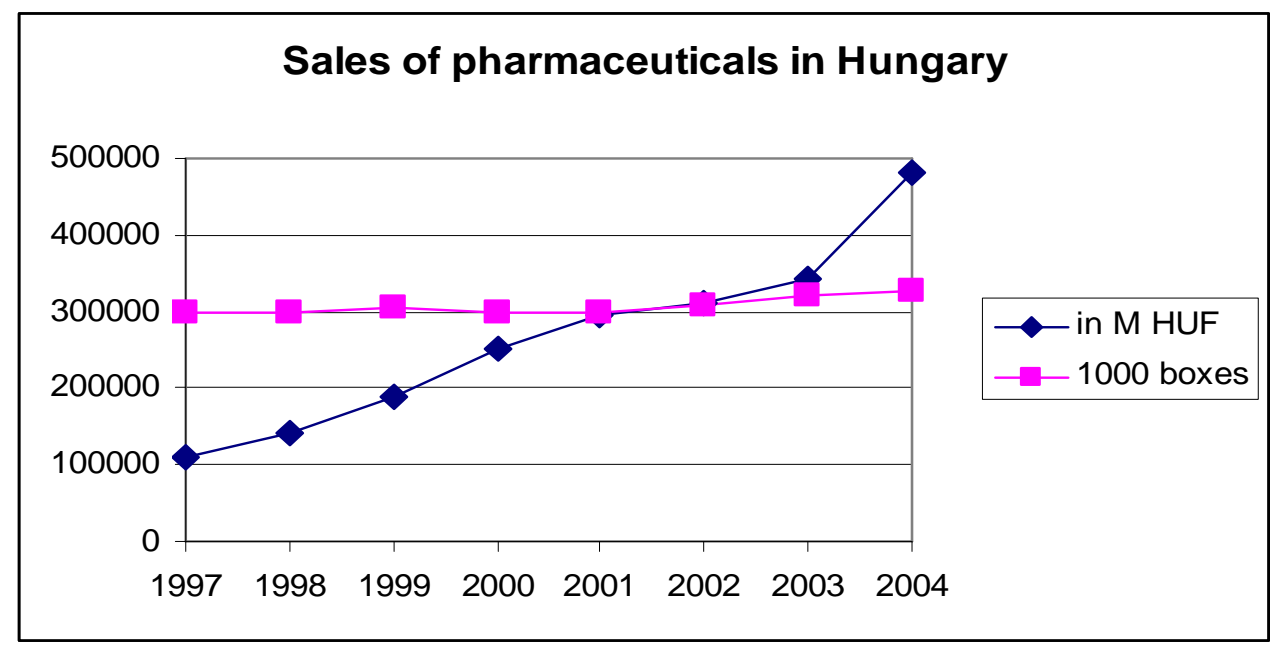

Tables 3.3-3.4 present detailed, not readily available information on the evolution of the pharmaceuticals industry between 1997 and 2002. ${ }^{7}$ While the number of employees decreased by 30 percent, net sales revenues increased by 40 percent during this period. It seems that exports played a major role in the increase of net sales revenues, as export sales rose by 68 percent. The increase in pre-tax profits and value added is even more spectacular, with 57 and 61.5 percent respectively. The improvements in the profits/sales and value added/sales ratios also indicate that the growth rate of revenues and profits was higher than that of sales. These favourable changes together with a substantial decrease in the number of employees resulted in increasing R\&D expenditure, sales and value added per capita terms. These indicators suggest that labour productivity increased substantially and the allocation of $R \& D$ funding became more efficient.

Table 3.3: Overview of the Hungarian pharmaceuticals industry, 1997-2002

\begin{tabular}{|l|r|r|r|r|r|r|}
\hline & $\mathbf{1 9 9 7}$ & $\mathbf{1 9 9 8}$ & $\mathbf{1 9 9 9}$ & $\mathbf{2 0 0 0}$ & $\mathbf{2 0 0 1}$ & $\mathbf{2 0 0 2}$ \\
\hline Number of employees (1000) & 15.6 & 15.7 & 14.8 & 14.4 & 13.5 & 11.1 \\
\hline Net sales revenue (bn HUF) & 187 & 210.2 & 218.4 & 265 & 292.4 & 262.8 \\
\hline Net export revenue (bn HUF) & 103.8 & 117.7 & 120 & 157.6 & 184 & 174.2 \\
\hline Pre-tax profits (bn HUF) & 45.3 & 39.1 & 38.1 & 49.5 & 70.2 & 71.4 \\
\hline Value added (bn HUF) & 85.9 & 98.2 & 96.9 & 125.6 & 145.6 & 138.8 \\
\hline Equity (bn HUF) & 53.3 & 53.3 & 54.4 & 57.8 & 53.8 & 49.6 \\
\hline Loan* (bn HUF) & 0.18 & 0.14 & 1.54 & 0.87 & 6.35 & 1.09 \\
\hline Foreign ownership (\% of equity) & 73.4 & 72.4 & 72.0 & 80.4 & 79.4 & 80.5 \\
\hline State ownership (\% of equity) & 8.8 & 8.8 & 13.6 & 8.1 & 8.7 & 9.4 \\
\hline
\end{tabular}

* loans specifically for investment and development purposes

Source: CSO and author's calculation

\footnotetext{
${ }^{7}$ Calculations are based on data from companies on double entry book keeping and employing more than 10 people.
} 
Table 3.4: R\&D intensity and efficiency of the Hungarian pharmaceuticals industry, 2000-2002

\begin{tabular}{|l|c|c|c|c|c|}
\hline & $\begin{array}{c}\text { R\&D } \\
\text { expenditure/ } \\
\text { employee* }\end{array}$ & $\begin{array}{c}\text { Sales/ } \\
\text { employee* }\end{array}$ & $\begin{array}{c}\text { Value added/ } \\
\text { employee* }\end{array}$ & Profits/ sales & $\begin{array}{c}\text { Value added/ } \\
\text { sales }\end{array}$ \\
\hline $\mathbf{2 0 0 0}$ & n.a. & 18.4 & 8.7 & 0.18 & 0.47 \\
\hline $\mathbf{2 0 0 1}$ & 1.28 & 21.6 & 10.7 & 0.24 & 0.49 \\
\hline $\mathbf{2 0 0 2}$ & 1.6 & 23.7 & 12.5 & 0.27 & 0.52 \\
\hline
\end{tabular}

*m HUF/head

Source: CSO and author's calculation

Another interesting feature is that while in 1997 the companies received only 183 m HUF in loans for investment and development purposes, this amount increased dramatically by 2002 .

\subsection{DETERMINANTS OF R\&D}

Until 1985, production of the biggest Hungarian pharmaceutical companies was scheduled according to the regulations of the Pharmaceutical Trust, which required that the companies manufactured complementary pharmaceuticals, to avoid competition. During the transition of the Hungarian economy, a significant amount of foreign investment flew to the pharmaceuticals industry, either via privatisation of the formerly state-owned companies or greenfield investments. As Table 3.3 shows, around $72-80$ percent of the industry is owned by foreign investors, while the Hungarian state hold a minor, 8 percent stake.

Foreign direct investment became a major determinant of $R \& D$ at the Hungarian companies. R\&D plays an increasingly important role in maintaining and improving the companies' competitive positions. It is even more so in the case of pharmaceutical companies, whose long-term competitiveness depends on their ability to innovate and develop original molecules. Companies mainly specialising in the production of generics cannot maintain a competitive edge over producers from the Far East, and recently introduced EU environmental protection regulations also pose difficulties for their operations. However, the funding required for the development and marketing of a new, original pharmaceutical has increased drastically as ever more complex clinical testing regulations have been introduced during the past decades. While the development of an original pharmaceutical product cost around $149 \mathrm{~m}$ Euros in 1975, its costs increased to $868 \mathrm{~m}$ euro by 2000 (AIPM, 2006). Prevailing regulations and requirements in the pharmaceuticals industry, such as the documentation of patent applications, tests required for the registration of new drugs and the qualification of the production technologies significantly increase the costs associated with research hand development. For this reason large TNCs have become the dominant actors in the pharmaceuticals industry all over the world, and small and medium-sized companies lost momentum due to their limited R\&D resources.

Foreign investment facilitated higher R\&D expenditure per researcher, and access to the most up to date technologies in Hungary, too. In contrast, the number of research personnel and projects decreased. Foreign direct investment, nonetheless, increased the competitiveness of the Hungarian pharmaceuticals companies, and accelerated the transformation of the industry's innovation model. Although the overall positive effects of foreign direct investment (which, besides the inflow of physical capital also included the transfer of 
technology, management skills and know-how) is unambiguous, it seems that in some cases it had an adverse impact on the R\&D activities of the Hungarian manufacturers. In many cases, the foreign owners re-allocated the R\&D capacities of the Hungarian affiliates in a way that serves cost-efficiency at the TNC level.

Figure 3.2 presents the 10 best performing Hungarian pharmaceuticals companies in terms of sales (bars), and market share (percentage indicated above bars).

Figure 3.2: The top 10 Hungarian pharmaceuticals firms, 1997-2004

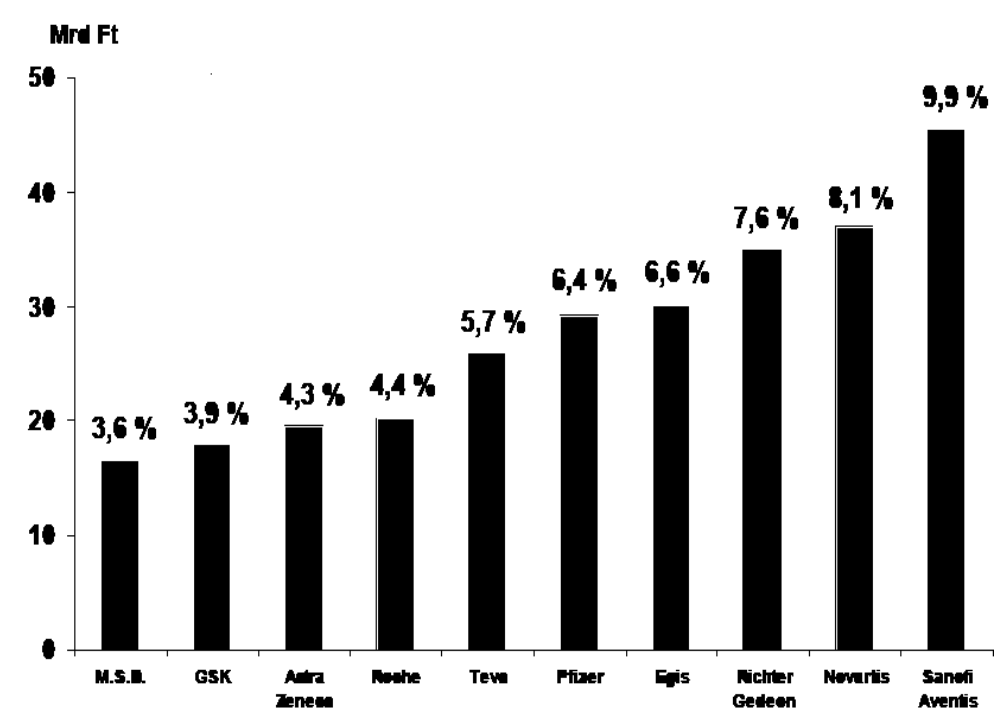

Source: Richter Gedeon Rt.

The oldest Hungarian pharmaceutical manufacturer is the Richter Gedeon Rt., which was established in 1901. As of today, Richter is the only independent pharmaceutical manufacturer, without strategic pharmaceutical investors. The Hungarian state still holds a 25.3 percent share of the company's stocks. Since 2001, Richter performs original research exclusively in the field of the central nervous system, and specialises in the development of painkillers, memory enhancing and neuro-protective formulas. Richter also holds a majority stake in the Polish pharmaceuticals manufacturer, GZF Polfa. The company aims to become a regional multinational company, and has already established manufacturing and logistics facilities in several CEE countries.

The main indicators of the company's performance are indicated in table 3.5. 
Table 3.5: Overview of Richter Gedeon Rt., 1997-2005

\begin{tabular}{|l|c|c|c|c|}
\hline & $\mathbf{1 9 9 7}$ & $\mathbf{2 0 0 2}$ & $\mathbf{2 0 0 4}$ & $\mathbf{2 0 0 5}$ \\
\hline Net revenue* $^{*}$ & 52.5 & 99.3 & 120.6 & 140.9 \\
\hline Export sales* & n.a. & n.a. & 85.9 & 100.1 \\
\hline Operating surplus* & n.a. & n.a. & 35 & 37.3 \\
\hline Pre-tax profits* & 17.8 & 20.6 & 37.4 & 43.6 \\
\hline After tax profits* & 16.6 & 28.1 & 37.1 & 43.6 \\
\hline R\&D expenditures* & 1.8 & 7.8 & 12.16 & 10.4 \\
\hline $\begin{array}{l}\text { R\&D intensity (\% of } \\
\text { sales revenues) }\end{array}$ & 6.5 & 7.9 & 8.2 & 8.6 \\
\hline Number of employees & 4,450 & 5,124 & 7,260 & 8,078 \\
\hline
\end{tabular}

$*$ in bn HUF

Source: Richter Gedeon Rt.

EGIS is another leading pharmaceutical manufacturer, which was established in 1913 and introduced its first original medicine in 1967. In 1991, strategic investors like the Japan Tobacco Inc injected capital into the company and the EBRD purchased 30 percent of the company's stocks. In 1995, Servier bought a 50.9 percent majority stake in EGIS. A further 42.9 percent of the company's stocks is held by foreign institutions and private investors.

Table 3.6: Overview of EGIS, 1997-2005

\begin{tabular}{|l|c|c|c|c|}
\hline & $\mathbf{1 9 9 7}$ & $\mathbf{2 0 0 2}$ & $\mathbf{2 0 0 4}$ & $\mathbf{2 0 0 5}$ \\
\hline Sales revenue* & 31.8 & 55.2 & 66.1 & 72.9 \\
\hline Domestic sales* & n.a. & n.a. & 26.9 & 29.7 \\
\hline Export (m USD) & 16.6 & 34.4 & 18.7 & 22.2 \\
\hline Operating surplus* & n.a. & 67 & 74.7 & 111.1 \\
\hline Pre-tax profits* & n.a. & 64.5 & 83.5 & 128.2 \\
\hline After tax profits* & n.a. & n.a. & 73.9 & 113.8 \\
\hline R\&D expenditures* & 2.3 & 3.78 & 4.85 & 5.33 \\
\hline $\begin{array}{l}\text { R\&D intensity (\% of } \\
\text { sales revenues) }\end{array}$ & 7.2 & 6.8 & 7.3 & 7.3 \\
\hline Number of employees & 2,714 & 2,708 & 2,733 & 2,716 \\
\hline Number of R\&D staff & 468 & 419 & n.a. & n.a. \\
\hline
\end{tabular}

*in bn HUF

Source: EGIS Rt.

The overall domestic sales of pharmaceuticals have been continuously increasing during the past few years. The same trend can be observed in most developed countries, where expenditures on pharmaceuticals increased by $5-10 \%$ per annum on average. This is partially due to the increasing price of pharmaceuticals, but more importantly to the volume and the composition effects. It seems that people tend to by more pharmaceuticals at a higher price, and the proportion of new, more expensive medicines has increased. In Hungary the composition effect is the major contributor to the increasing expenditure and the government encourages changes to the structure of consumption in favour of the more extensive application of generic medicines (GKI, 2006). In order to decrease the imbalance caused by the subsidised medicines, since 2003, Hungarian pharmaceuticals manufacturers pay contributions to the Social Security Fund according to their market share. Total contributions 
to the Fund amounted to 9 bn HUF in 2004, 20 bn HUF in 2005 and projected to reach 22.5 bn in 2006.

Since Hungary has joined the EU, significant changes have been introduced to the regulation of the pharmaceuticals industry in order to ensure the harmonisation of the legal framework. The most important policy document that had to be implemented was the Directive on Transparency that helped the transition of the Hungarian system. As a result of pressure from the industry's associations, a revised version of this policy has been issued, which is acceptable to all parties. Based on this experience, the Implementation strategy of the Future Medicine Legislation is being developed together with chambers and industrial associations.

\subsection{IMPACT OF R\&D}

Studies and sectoral analyses that systematically analyse the relationship between R\&D and company performance in the pharmaceuticals industry are not available, except for the work of Reiter (2005). Occasionally press releases and studies that examine the state of R\&D in Hungary shed some light on certain aspects of the issue. Further information is on the industry level is available from the time series data presented in Section 1, and from the associations of the Innovative Pharmaceutical Manufacturers and the Hungarian Pharmaceutical Manufacturers. Company level information is available for the companies listed on the stock exchange, i.e. Egis, Richter, Phylaxia-Pharma and HUMET.

Since most Hungarian pharmaceutical manufacturers are part of the production networks of professional foreign investors, the evolution of R\&D activities can only be discussed in the context of the transnational R\&D strategy of the foreign owners. The effects of foreign ownership on the evolution of research at the Hungarian companies are demonstrated by the following examples.

Servier, which places a high value on innovation and original research in its transnational R\&D strategy, holds a majority ownership in Egis. The company's goal, therefore, has been to maintain and improve the research capacities of Egis, and to integrate these into the company's strategic projects. Due to the limited financial resources of Servier, Egis must compete for R\&D funding with the other research centres of the holding. In many cases it means that Egis performs research only in specified phases of the project. The prospects of Egis for further funding for original molecule development have dramatically decreased since the failure of its Deram-ciclane molecule in the third phase of clinical testing. The R\&D resources at Egis amount to 6-8\% of its annual sales revenue.

Sanofi-Winthrop Holding is the dominant professional investor in Chinoin. Although Sanofi supports the development of new products of Chinoin, the majority of the R\&D activities are performed at its R\&D centre in Gentilly, France. With a strongly centralised R\&D strategy, Sanofi employs less researchers with higher research funding per head. Research at Chinoin focuses on molecules affecting the central nervous system and specific research tasks or performs research in specified phases of the project.

Teva (and Orvet Gmbh) holds 98.9 and 99 percent stakes in Human and Biogal, respectively. Teva is one of he main generics providers of the world and it concentrates its resources in the development of only a few, strategic pharmaceuticals. Original R\&D at Human and Biogal, therefore, does not have a high priority for the company. Teva has cut the number of research 
personnel by $50 \%$ at Biogal, and implemented a major reorganisation at the $\mathrm{R} \& \mathrm{D}$ department. Biogal spends about $3-4 \%$ of its annual sales revenue on $R \& D$ - that is, way below the industry average -, mainly on specific small projects. The research activities of the company are co-ordinated form Teva's headquarters.

During the planned economy era, pharmaceuticals research was centralised at the Gyógyszerkutató Intézet. In 1998 Ivax purchased the majority of the company's shares and research of the Gyógyszerkutató Intézet became part of the company's global programme. The financial position of Ivax is more limited than that of the previous companies, and on a global scale it employs around 700 researchers to develop 30-50 generic and original medicines. Due to the limited resources of Ivax, the risk of financing these projects is also more substantial. Therefore funding for the Gyógyszerkutató Intézet's own original molecule development programmes is very limited, and concentrated mainly in tumour-related medication.

ICN (Valeant) holds the majority ownership in Alkaloida. Although Alkaloida was one of the most original-research-intensive companies in Hungary, from 1995 ICN has gradually decreased the number of research projects. Alkaloida produced substantial losses since the late 1990 s, and thus the amount of R\&D spending was decreased to only $0.7 \%$ of the annual sales revenues in 2001, and employment was cut, too. Currently, the resources of ICN allow only for the development of 2-3 original pharmaceuticals per year. This means that funding is generally not available for Alkaloida's original development projects.

These examples and Reiter (2005) suggest that the most important effects of foreign ownership on the R\&D performance of the Hungarian companies are as follows. Besides the transfer of capital, foreign investment has also facilitated the transfer of modern technologies, and procedures like the in vitro method, as well as marketing, management know-how. Due to the financial strengths of the parent companies, funding for research have become available, and chances for developing a product from the original molecule and taking it to the market increased. The allocation of R\&D expenditures has become more efficient and the exploitation rate of research results increased. Given these factors, the competitiveness of Hungarian companies has improved on the global market. Since the parent companies operate on a global scale, the risk of concentrating resources on one particular project at the Hungarian manufacturer has decreased, local projects, therefore, are more likely to be supported. As the Hungarian companies have become integrated to the global production networks of their parent companies, the possibilities for international co-operation increased. Also, the domestic companies have gained access to the international markets via the networks of their foreign owners.

The foreign investors, however, have also significantly restructured the R\&D system of their Hungarian affiliates. In most cases, $R \& D$ at the Hungarian companies have become a subsystem in the global R\&D programme of the parent companies, which determines in global terms what type of research is to be performed by the Hungarian subsidiaries. As a result, research at the Hungarian manufacturers is restricted to areas specified in the global R\&D strategy, and it is even more so in the case of original research performed only in specific areas. New product development of the domestic companies has decreased, as well as the number of patent applications for original products, which is also due to the introduction of product patents (replacing process patents). The transition from the process-patent to a product-patent system has meant that Hungarian manufacturers have had to introduce a dramatically new approach to research. The range of products has also decreased in many 
cases, because the parent company has replaced Hungarian products by its own products. Another visible effect has been that cooperation between domestic companies and universities has become more limited, and it is performed mainly in the field of developing analytical tests.

\section{Box 3.1}

\section{R\&D at a pharmaceuticals manufacturer}

The development of original drug molecules has always been in the focus of the company's R\&D strategy. R\&D activities are performed in two departments, with a $25.4 \mathrm{~m}$ Euro budget allocated for each. The research department covers the quest for new, original drug-molecules and compounds, while the development department focuses on generic molecules. The research and the development department employ 600 and 150 researchers, respectively. The two departments' activities are not strictly separated, they often co-operate on various issues. Both departments are engaged in the entire cycle of drug development. In case of original development, the cycle starts from the generation of the initial idea to the late clinical phase, through indication, identifying target molecules, compounds, pre-clinical and early clinical tests. In case of generic development, the cycle covers the process from monitoring available patents up to drug registration. These activities result in both product and process developments, as process development is required for the creation of each new substance, or drug formula.

During the 2000-2004 period, the research department of the company went through a considerable transformation, which resulted in the improvement of scientific standards and accelerated the research projects. As of today, the company's research activities match those of the leading pharmaceuticals companies of the world in terms research personnel, sectoral standards and research infrastructure. The bulk of the company's revenues is generated by generic drugs, and thus day-today operation is based on the development of generic molecules. The composition of sales by original vs. generic products remained relatively constant in the past decade. In 2005, $17 \%$ of sales was generated by products stemming from the company's original research, that is, the so-called innovative drugs, and $70 \%$ was accounted for by reproduction and generic products. A further $13 \%$ of the revenues was generated by products licensed by other international companies. The company launches 3-7 generic drugs a year.

Although R\&D is seen as a key factor behind the company's success, a number of factors have been identified as potential sources that hamper R\&D. The company sees the lack of appropriate financial resources as the biggest threat to its $R \& D$ activities, because the development of original molecules requires significant funds. Therefore the company signed mutually beneficial research agreements with a US-based laboratory to cooperate in the expensive clinical trial phase. Research and development in the industry has become a global activity, and a great importance is given to the collaboration agreements established by the company. The company seeks strategic partners to share the costs of clinical tests in the socalled human phase, which requires large capital investment.

The lack of appropriate personnel seems to be another threat for R\&D. The supply of well trained experts in pharmaceuticals-related fields such as drug formula design, toxicology, and chemistry is insufficient in Hungary. This is due to the reason that natural science is not popular among students, and also because experts often move from the pharmaceuticals industry to environment protection agencies. 


\subsection{SUMMARY}

We can conclude that the pharmaceuticals industry is one of the best performing and most R\&D intensive sectors of the Hungarian economy. However, the research system has gone through a number of substantial modifications since the early 1990s. The most important factor behind these changes is that foreign pharmaceuticals manufacturers became majority owners in most companies, who pursued an integrated R\&D strategy at the global level. As a result, the number of research projects decreased, but the allocation of $R \& D$ expenditures became more efficient. New research projects at the Hungarian companies focus on the development of generic medicines and R\&D on original molecules is rather limited.

\subsection{REFERENCES}

Association of the Innovative Pharmaceuticals Manufacturers, Newsletter 2006/1, www.igy.hu

CEFIC: Facts and Figures, 2005, www.cefic.org

EGIS Rt Annual Report 2005, www.egis.hu

Eurostat [2005]: Panorama of the European Union, European Business Facts and Figures 1995-2004, http://epp.eurostat.cec.eu.int/portal/

GKI Health Research Institute, http://www.gki-eki.hu/

Reiter, J. [2005]: A magánosítás hatása a nemzeti kutatás-fejlesztésre a közép-európai gyógyszergyárak esetében (Effects of privatisation on national R\&D in the CEE pharmaceuticals sector), Gazdaság és Statisztika, Vol. 17, No. 3, p 8

Richter Gedeon Rt Annual Report, www.richter.hu 


\section{SECTOR STUDIES: MANUFACTURE OF ELECTRICAL EQUIPMENT FOR ENGINES AND VEHICLES; MANUFACTURE OF PARTS AND ACCESSORIES FOR MOTOR VEHICLES AND THEIR ENGINES}

\subsection{INTRODUCTION}

Automotive industry has traditionally been a front-runner in globalising its activities, originally in the forms of trade and licensing agreements, as early as the beginning of the twentieth century, and then in the form of cross-border investment projects. The main drivers for the major automotive firms to invest in new host countries are cutting costs via re-location of production, and gaining access to new markets in emerging economies. They have become rather active in Central Europe, too: practically all major automotive groups, both assemblers and component manufacturers, have already set up their operations in Central Europe, or are building their new plants. (Havas, 2000a, 2004; Pavlinek 2002a, 2002b; country studies for this project) Given these strategic moves, the Hungarian automotive industry has been radically re-shaped: car production started again in Hungary in the early 1990s - after a halfa-century 'recess', and suppliers became parts of the global production networks, either via ownership or subcontracting relationships. In brief, new products are manufactured by new entrants or fundamentally transformed incumbent firms, using new production and management techniques, and serving new customers.

Two sectors are analysed in detail in this report, because they are closely related: although statistically they belong to different sectors, in essence both of them are parts of automotive industry, broadly defined. One of them has been selected for this project because of its high R\&D-intensity (in the Hungarian context), that is, manufacture of parts and accessories for motor vehicles and their engines (NACE 34.3). The other one has been chosen due to its fast growing R\&D-intensity, namely, manufacture of electrical equipment (NACE 31.6). This latter sector covers the sub-sector called manufacture of electrical equipment for engines and vehicles (NACE 31.61)

A methodological note is required here on the classification of various automotive sectors. Automotive component manufacturing was not considered a separate industry in international statistics until the 1980s. In the first decades of car manufacturing, independent companies supplied parts as a side business, along with machines, instruments, and parts for other transport equipment, such as bicycles and carriages. Later, car manufacturers either acquired their suppliers or established in-house production of components. Thus, information and statistics on this sector used to be subsumed under the automobile or motor vehicle industry. In the 1980s, however, automotive parts emerged as an important industry in its own right because of changes in technology, organisation and trade. The role of component suppliers increased not only in production but also in design; their technical and economic performance has became a key factor in the competition among car manufacturers. Thus, the sector has become an 'entry' in statistics due to its economic significance. A simple reason is that on average 10000-12000 parts are built into a car, accounting for some 50-70\% of the manufacturing cost of an automobile.

As a very wide range of products are used to assemble a motor vehicle - practically all industrial sectors supply the automotive industry -, readily available statistics are usually too 
narrow in terms of coverage. In other words, quite a few automotive suppliers are classified as leather, rubber, plastics, paint, glass, cable or metal producing and processing companies, foundries, electrical and electronics companies, etc. The EU statistical classification also follows this line, i.e. motor vehicle parts and accessories (NACE 34.30) excludes engine and tyre manufacturers, most of the electrical and electronic components, as well glass, plastic or certain castings and other metal parts.

The current Hungarian statistical classification system, ${ }^{8}$ practically in harmony with the EU methodology, identifies four automotive sub-sectors:

manufacture of electrical equipment for engines and vehicles (31.61);

manufacture of motor vehicles (34.10);

manufacture of bodies (coachwork) for motor vehicles (34.20), and

manufacture of parts and accessories for motor vehicles and their engines (34.30).

As already mentioned, two of these sectors are analysed in this study, given the level and growth rate of their R\&D activities: manufacture of electrical equipment for engines and vehicles (31.61) (henceforth: electrical automotive components), and manufacture of parts and accessories for motor vehicles and their engines (34.30) (henceforth: manufacture of automotive components). Although these names might suggest that these two sectors cover at least the majority of automotive suppliers, this is not the case: just as in the EU statistics on the automotive components sector, a wide range of products are excluded (e.g. engines, tyres, glass, plastic, castings and other metal parts as well as bulbs). For this reason available statistics only included 150-160 firms in the early 1990s, while experts estimated that altogether some 300-350 companies were producing motor vehicle parts and components in Hungary. ${ }^{9}$ Partly due to a better statistical coverage, and in part due to a genuine increase in the number of companies, the 2001 data already covered some 250 firms in the two sectors are analysed here, namely 3161 and 3430.

The share of the automotive components industry in the national GDP has grown to $0.8 \%$ by 2003, thanks to a healthy growth in its production value (from $1000 \mathrm{~m}$ euro in 1998 to 2049 $\mathrm{m}$ euro in 2003).

The private R\&D expenditures in NACE 34.3 amounted to 12.5 m euro in 2004 , up from 4.2 $m$ euro in 1998. The share of $R \& D$ expenditures of the automotive components industry in the total BERD amounts to $4.2 \%$, that is, $5.2 \%$ of the private $R \& D$ expenditures in the manufacturing industry.

\footnotetext{
${ }^{8}$ It was introduced in 1992. Previously components manufacturing, in line with the previous international methodology, was treated as part of the automotive industry.

${ }^{9}$ The primary producers are Rába (diesel engines and axles for commercial vehicles), Bakony Mủvek (electrical parts), MMG (instrument panels), PEMÜ, TVK, Kaloplasztik, Kunplast (all plastic parts), Perion (batteries), IMAG (seats, wiring harnesses), Videoton (printed circuits, electrical parts and wiring harnesses), KnorrBremse (brakes), ADA, Pre-cast and Le Belier (all foundries), GE Tungsram (lighting) and Taurus (rubber parts). Besides these long-established Hungarian companies - some of them already privatised by foreign investors as their new names suggest - well-known foreign companies have also set up their subsidiaries, e.g. Akzo (paints), Ford (electrical parts), Cascade and Happich (plastic parts), Denso (fuel pumps), ITT Automotive (electrical parts and wiring harnesses), Michels Kabel (wiring harnesses), Packard Electric (electrical parts and wiring harnesses), UTA (wiring harnesses), VAW (castings) and ZF (gearboxes). The major customers are the local car assemblers, Western European carmakers and their first-tier suppliers, as well as North American commercial vehicle companies.
} 
The number of researchers has more than doubled since 1998. The total number of researchers was 367 (head counts) in 2004, which represents around $4 \%$ of the total number of researchers in the private sector.

The share of the other electric equipment industry - essentially electrical equipment for engines and vehicles - in the national GDP has reached to $0.3 \%$ by 2003 , thanks to a healthy growth in its production value (from $317.5 \mathrm{~m}$ euro in 1998 to $1092 \mathrm{~m}$ euro in 2003).

The private R\&D expenditures in NACE 31.6 amounted to 2.9 m euro in 2004, up from 0.4 $m$ euro in 1998. The share of $R \& D$ expenditures of the electrical automotive components industry in the total BERD amounts to $1 \%$, that is, $1.2 \%$ of the private $\mathrm{R} \& \mathrm{D}$ expenditures in the manufacturing industry.

The number of researchers has increased 2.5 times since 1998. The total number of researchers was 85 (head counts) in 2004, which represents around $1 \%$ of the total number of researchers in the private sector.

At several points in this paper, data for another automotive sub-sector, namely manufacture of motor vehicles (34.1), are also presented to facilitate a brief comparison between 34.1 and 34.3. R\&D data for the third sub-sector belonging to the NACE 34 group, namely manufacture of bodies (coachwork) for motor vehicles; manufacture of trailers and semitrailers (NACE 34.2) cannot be presented due to the data protection regulation: less then 3 companies are pursuing $R \& D$ activities in this sub-sector.

\subsection{PatTerns, NATURE AND SOURCE OF R\&D}

R\&D data are available at a 2-digit sectoral level only for 5 sectors in Hungary, including manufacture of electrical machinery and apparatus (NACE 31), but not including manufacture of transport equipment (that is, motor vehicles, trailers and semi-trailers; NACE 34). R\&D data at a 3-digit level are not published at all. The Hungarian Central Statistical Office, however, has kindly provided data on BERD at a 3-digit sub-sectoral level, free of charge, to assist our team in selecting the four sectors for this project. As funding for purchasing further data - e.g. R\&D employment, major data for calculating concentration ratios to describe the structure of the selected sectors, has not been made available, as a first approximation we rely on these data, i.e. BERD - to characterise recent trends in R\&D in these two sub-sectors. ${ }^{10}$ This dataset are completed with a third sub-sector, namely manufacture of motor vehicles (NACE 34.1), in order to provide a background to compare car and components manufacturing (34.1. vs. 34.3). (Table 4.1)

\footnotetext{
${ }^{10}$ NACE 31 includes manufacture of lighting equipment and electric lamps (NACE 31.5), which is a major industry in Hungary, due to the operations of a large company, that is a subsidiary of GE Electric, used to be called Tungsram. Presenting publicly available data on R\&D expenditures and employment at a 2-digit level (NACE 31) would be misleading for the purposes of this report, due to the huge difference in terms of the dynamics - strategy, technological and market opportunities, industry structure and other major drivers of R\&D activities - in sub-sectors 31.5 and 31.6.
} 
Table 4.1: BERD in three sub-sectors producing automotive products, 2001-2004 (current m HUF)

\begin{tabular}{rrrrr}
\hline & 2001 & 2002 & 2003 & 2004 \\
\hline NACE 31.6 & 567,978 & 416,243 & $1,645,404$ & $3,543,586$ \\
NACE 34.1 & $3,076,905$ & 944,181 & $1,272,561$ & $3,379,996$ \\
NACE 34.3 & $1,573,872$ & $1,722,505$ & $4,253,237$ & $2,301,585$ \\
\hline
\end{tabular}

Source: CSO

Eurostat, however, is publishing data on intra-mural $\mathrm{R} \& \mathrm{D}$ expenditures and on $\mathrm{R} \& \mathrm{D}$ employment for all these three sub-sectors at a 3-digit level, as well as BERD data at a 2-digit level for the Hungarian automotive industry (NACE 34) since 1998. (Tables 4.2-4.5) Two caveats are in order. First, it needs to be emphasised - what is already said - that Eurostat data at a 3-digit level refer to intra-mural R\&D expenditures, not BERD, and thus CSO data and Eurostat data are not comparable. Second, the 2003 figure for intra-mural R\&D expenditures in sub-sector 34.1 represents an unrealistic jump, that is, nearly a 50-times higher amount. (This figure is highlighted by a yellow background in Table 4.4) This sudden jump makes one curious, indeed, as R\&D personnel actually shrunk in the 34.1 sector in 2003.

Table 4.2: R\&D indicators of Manufacture of electrical equipment n.e.c. (NACE 31.6), and Manufacture of electrical equipment for engines and vehicles n.e.c (NACE 31.61), Hungary, 1998-2003

\begin{tabular}{lrrrrrr}
\hline & 1998 & 1999 & 2000 & 2001 & 2002 & 2003 \\
\hline Total intra-mural R \& D expenditure (m €) & 0.4 & 1.0 & 1.0 & 1.0 & 1.0 & 2.0 \\
$\quad$ of which 31.61 & 0.4 & 0.9 & 1.0 & 0.9 & $:$ & $:$ \\
Total number of R \& D personnel (head) & 39 & 65 & 48 & 87 & 99 & 80 \\
$\quad$ of which 31.61 & 36 & 60 & 46 & 81 & $:$ & $:$ \\
Share of R\&D exp. in value added (\%); 31.6 & $:$ & $:$ & 0.3 & 0.5 & 0.4 & 0.5 \\
Share of R\&D exp. in value added (\%); 31.61 & $:$ & $:$ & 0.5 & 0.3 & $:$ & $:$ \\
Share of R\&D employment in the number of & $:$ & $:$ & 0.2 & 0.3 & 0.3 & 0.3 \\
persons employed (\%); 31.6 & & & & & & $:$ \\
$\begin{array}{l}\text { Share of R\&D employment in the number of } \\
\text { persons employed (\%);31.61 }\end{array}$ & $:$ & $:$ & 0.3 & 0.5 & $:$ & $:$ \\
\hline
\end{tabular}

Source: Eurostat

: not available 
Table 4.3: R\&D indicators of Manufacture of motor vehicles, trailers and semi-trailers (NACE 34), Hungary, 1998-2003

\begin{tabular}{lrrrrrr}
\hline & $\mathbf{1 9 9 8}$ & $\mathbf{1 9 9 9}$ & $\mathbf{2 0 0 0}$ & $\mathbf{2 0 0 1}$ & $\mathbf{2 0 0 2}$ & $\mathbf{2 0 0 3}$ \\
\hline BERD $(\mathrm{m} €)$ & 5.5 & 7.4 & 6.2 & 18.3 & 11.1 & 21.8 \\
Total number of R\&D personnel (head) & 301 & 308 & 381 & 524 & 990 & 433 \\
Share of R\&D expenditure in value added $(\%)$ & $:$ & $:$ & 0.6 & 1.1 & 1.3 & 11.1 \\
Share of R\&D employment in the number of & $:$ & $:$ & 1.1 & 1.4 & 2.7 & 1.1 \\
persons employed $(\%)$ & & & & & &
\end{tabular}

Source: Eurostat

: not available

Table 4.4: R\&D indicators of Manufacture of motor vehicles (NACE 34.1), Hungary, 1998-2003

\begin{tabular}{lrrrrrr}
\hline & 1998 & 1999 & 2000 & 2001 & 2002 & 2003 \\
\hline Total intra-mural R \& D expenditure (m $€)$ & 0.5 & 2.1 & 1.0 & 4.2 & 3.0 & $144.4^{*}$ \\
Total number of R \& D personnel (head) & 145 & 77 & 26 & 123 & 114 & 106 \\
Share of R\&D expenditure in value added $(\%)$ & $:$ & $:$ & 0.1 & 0.6 & 0.4 & 17.4 \\
Share of R\&D employment in the number of & $:$ & $:$ & 0.3 & 1.2 & 1.1 & 1.1 \\
persons employed $(\%)$ & & & & & &
\end{tabular}

Source: Eurostat

: not available

* probably a mistake

Table 4.5: R\&D indicators of Manufacture of parts, accessories for motor vehicles (NACE 34.3), Hungary, 1998-2003

\begin{tabular}{lrrrrrr}
\hline & 1998 & 1999 & 2000 & 2001 & 2002 & 2003 \\
\hline Total intra-mural R \& D expenditure $(\mathrm{m} €)$ & 4.2 & 4.2 & 5 & 8.2 & 13.7 & 15.5 \\
Total number of R \& D personnel (head) & 156 & 189 & 294 & 331 & 869 & 327 \\
Share of R\&D expenditure in value added $(\%)$ & $:$ & $:$ & 1.2 & 1.7 & 2.8 & 2.7 \\
$\begin{array}{l}\text { Share of R\&D employment in the number of } \\
\text { persons employed }(\%)\end{array}$ & $:$ & $:$ & 1.3 & 1.3 & 3.4 & 1.2 \\
\hline
\end{tabular}

Source: Eurostat

: not available

Tables 4.6-4.7 indicate that one of these sectors, namely 31.61 was significantly below the national average of the manufacturing industry in 2000-2001, if R\&D-intensity is measured by the share of $R \& D$ expenditures in value added, but closer to that average when $R \& D$ employment is taken as a measure. This simple exercise suggests that R\&D expenditures per $\mathrm{R} \& \mathrm{D}$ employees were much lower in this sub-sector than the national average in the given period. One should also bear in mind, however, that data are missing from the Eurostat database for 2002-2004, and this sub-sector has been selected for our study exactly for the high growth rate of R\&D expenditures: almost a 7-times higher amount in 2004, compared to 2001. (Table 4.1) Thus, available data do not permit to draw firm conclusions as far as the R\&D-intensity of this sector is concerned. 
NACE 34.1 presents a similar case: lower R\&D-intensity then the manufacturing industry average when it is measured in expenditures, but a higher one when employment is taken into account. (The dubious $2003 \mathrm{R} \& \mathrm{D}$ expenditures figure is disregarded here.)

In contrast, NACE 34.3 is way above the national manufacturing average ( 2 and 5 times higher intensity), if either measure is taken; actually, that has been the selection criteria for this sub-sector. In this case, both CSO and Eurostat data point to the same conclusions (as the selection has been made on the basis of CSO data). Given the strong performance of this subsector, the automotive industry at a 2-digit level is close to the Hungarian manufacturing industry average when R\&D expenditures are taken into account, and 4 times above that average if employment figures are taken as an indicator.

Table 4.6: Share of R\&D expenditure in value added (\%), Hungary, 2000-2003

\begin{tabular}{lrrrr}
\hline & $\mathbf{2 0 0 0}$ & $\mathbf{2 0 0 1}$ & $\mathbf{2 0 0 2}$ & $\mathbf{2 0 0 3}$ \\
\hline Manufacturing (NACE D) & 1.5 & 1.3 & 1.4 & $:$ \\
NACE 31.61 & 0.5 & 0.3 & $:$ & $:$ \\
NACE 34 & 0.6 & 1.1 & 1.3 & 11.1 \\
NACE 34.1 & 0.1 & 0.6 & 0.4 & 17.4 \\
NACE 34.3 & 1.2 & 1.7 & 2.8 & 2.7 \\
\hline
\end{tabular}

Source: Eurostat

: not available

Table 4.7: Share of R\&D employment in the number of persons employed (\%), Hungary, 2000-2003

\begin{tabular}{lrrrr}
\hline & $\mathbf{2 0 0 0}$ & $\mathbf{2 0 0 1}$ & $\mathbf{2 0 0 2}$ & $\mathbf{2 0 0 3}$ \\
\hline Manufacturing (NACE D) & 0.7 & 0.5 & 0.7 & $:$ \\
NACE 31.61 & 0.3 & 0.5 & $:$ & $:$ \\
NACE 34 & 1.1 & 1.4 & 2.7 & 1.1 \\
NACE 34.1 & 0.3 & 1.2 & 1.1 & 1.1 \\
NACE 34.3 & 1.3 & 1.3 & 3.4 & 1.2 \\
\hline
\end{tabular}

Source: Eurostat

: not available

EU25 data on the R\&D-intensity of the above sectors are not available in the annual detailed enterprise - or structural business -statistics of Eurostat, and thus R\&D-intensity of the above Hungarian sectors cannot be compared to the EU25 average.

As part of the European TrendChart on Innovation project, European Sector Innovation Scoreboards have also been compiled for EU15 countries. (Hollanders and Arundel [2005]). Using 12 indicators, a so-called innovation sector index (ISI) has been computed, to rank sectors (a t a 2-digit level) by their innovation performance. Automotive industry ranks five, with its 0.57 ISI. The top four sectors are electrical and optical equipment (0.63); information ad communication technologies (0.61); computer services and related activities (0.59); chemicals and chemical products (0.58). Of the 12 indicators used to compare sectoral 
innovation performance, only one is available for the Hungarian sectors manufacturing automotive products, namely $\mathrm{R} \& \mathrm{D}$ expenditures as percentage of value added. The average for the automotive industry in EU15 countries is $7.6 \%$ for this indicator (as opposed to 1.7\% for all NACE sectors), that is, around 5 times higher than the Hungarian one at a 2-digit level (NACE 34), and almost 3 times higher than the R\&D-intensity of NACE 34.3 in Hungary.

\subsection{DETERMINANTS OF R\&D}

\subsubsection{Traditions of the Hungarian Car and Car Components Industries}

\subsubsection{Craft production before 1945}

Cars, first assembled from imported kits, have been produced in Hungary since 1903. 1905 saw the first car designed and built by a Hungarian engineer, János Csonka. Bus manufacturing started in 1909. Preparation for World War I sparked production of cars, trucks, and engines. Ravages of war and The Great Depression hindered the sector in the 1920s. Recovery started in the 1930s, including the assembly of Ford models under a licence agreement. Motorcycle production commenced in the 1930s, too. First imported kits were assembled but local content had increased to ninety per cent by 1935 . World War II boosted production again, particularly for military vehicles (Berend and Ránki, 1955, 1958). All the major car parts - engines, gears, and chassis - had also been produced in Hungary until the mid-1940s. In other words, Hungary's vehicle manufacturers have not been mere assembly units of foreign companies, but have accumulated skills in automotive engineering, building upon a long tradition in mechanical engineering.

Hungarian engineers were rather successful in $R \& D$ in the pioneering period of the industry. The most notable ones were János Csonka and Donát Bánki who substantially improved the internal combustion engine in many ways in the 1880s and 1890s. Their most significant but hardly acknowledged - achievement was the invention of the carburettor in 1893. Bánki also designed a new engine that raised efficiency fifty percent. These R\&D results, however, were not commercialised in a large scale production in Hungary. Not even the carburettor, what was re-invented by Maybach in Germany two years later, and that version became known all over the world.

\subsubsection{Heritage of the CMEA}

Automotive production facilities were ruined during the war. Manufacturing of motorcycles, buses, lorries and other commercial vehicles resumed after the war. ${ }^{11}$ Car production, however, was abandoned under a new industrial policy, which shaped Hungary's industrial structure to a CMEA-wide division of labour. The new policy first was influenced informally by Soviet advisors working in Hungary and then by a formal Soviet-Hungarian specialisation agreement signed in 1964. The accord co-ordinated the two countries' industrial development projects, including automotive manufacturing, in the wider context of CMEA. It also stipulated that Hungary would specialise in producing buses for the entire CMEA. ${ }^{12}$ Ikarus,

\footnotetext{
${ }^{11}$ Private companies - like in all other sectors, and in all other countries in the Soviet block - were nationalised by the late 1940s. Corollaries of nationalisation and central planning - most notably lack of competition - are not of sector specific, and thoroughly analysed in the literature, hence not discussed here.

12 For a detailed analysis of the impacts of the agreement and the 'Central Automotive Development Programme' see Bauer et al. (1980), Bauer and Soós (1980), Soós (1980) and Tárnok and Vince (1980).
} 
Hungary's bus manufacturing firm became one of the largest in Europe, turning out some 14,000 units a year in the 1980 s. $^{13}$

Bus manufacturing provided an excellent opportunity to make use of the considerable assets and skills accumulated in car components manufacturing companies, in spite of the lack of car manufacturing since the late 1940s. Hungarian suppliers also shipped car parts to other CMEA countries since the 1960s. ${ }^{14}$ Certain automotive components, e.g. engines, axles, undercarriages and tyres for commercial vehicles as well as bulbs, batteries and dash boards for cars, were also exported for hard currencies (to Western Europe, the US and India).

As for $\mathrm{R} \& \mathrm{D}$, hardly any original project was conducted in this period in a sharp contrast with the pre-war era. The pace of technological improvement was set by CMEA demand. Needless to stress how different these requirements were compared to those of advanced countries, given the severe shortage of cars and the lack of rigorous safety and environmental regulations. The only counterbalancing factor was that CMEA car manufacturers, expect Skoda, based their product development strategy on Western licences since the 1960s. Hence, their suppliers' products were also based on Western licences. The most advanced product and process technologies, however, were not made available through these licence agreements. In other words, it was a 'safe' way to maintain or even widen the technological gap. In fact, due to the lack of incentives to innovate - that is, no import competition at all, extremely long queues for effectively rationed cars, lack of up-to-date safety and environmental rules - CMEA car producers were happy in the 1980s with their 30-40-year old technologies. Their Hungarian suppliers, therefore, had hardly any opportunity and incentives to innovate, either. Those suppliers, however, that exported their products for hard currencies had no other choice than to continuously improve their products through up-todate Western licences (e.g. from Bosch, MAN, KNORR, ZF, Girling, Lucas) and adaptive inhouse $R \& D$ projects.

\subsubsection{Re-emerging Car Production in Hungary}

Hungarian government officials had long intended to re-establish car industry for two basic reasons. First, the severe shortage of cars was rather annoying in this reformed planned economy - often referred to as 'goulash communism' in Western media. This shortage resulted in an ageing, obsolete car population. (Havas, 1997) Second, the government also viewed car manufacturing as a means of industrial modernisation, with its exacting technical and organisational requirements. Industrialists also backed the idea as a major step toward integration into the world economy - and as another golden opportunity to obtain big slices of investment funds from the government. Eventually, two consortia were set up by Hungarian companies to promote the re-establishment of car industry in the late 1980s.

One question has, however, divided this apparently unified camp of promoters, namely whether to opt for large scale manufacturing of components for major car producers or to

\footnotetext{
${ }^{13}$ Production was still 12,350 and 11,980 units in 1988 and 1989, respectively. Collapse of CMEA has caused a dramatic drop: output fell to 7,994 in 1990, and almost every year has seen a further decline since then. Output was a mere 1,576 units in 1994 and 1,162 buses in 1998, dropped to around 100 in the early 2000s.

14 The single most important buyer has been the (former) Soviet VAZ (Lada) factory. Other significant customers have included the Polish FSO and FSM (Polski Fiat) companies as well as Dacia in Romania. Although (the former) Yugoslavia never joined the CMEA, Hungarian parts were also shipped to her car producer, Zastava (now in Serbia) until the UN embargo in the late 1990s. Given the lack of sectoral statistics for that period, data on aggregate automotive sales to the CMEA are not available.
} 
assemble cars again, after a rather long interval, lasting for almost 50 years. ${ }^{15}$ It was also an open and much debated question whether to try to mount assembly operations within the framework of the CMEA, or in co-operation with the advanced countries. While the government pondered the issue, two foreign car companies - Suzuki and GM Opel - looking for favourable new locations and market opportunities, 'resurrected' the Hungarian car manufacturing in the early 1990s.

Magyar Suzuki, a Japanese-Hungarian joint venture located in Esztergom, some $50 \mathrm{~km}$ of Budapest, commenced commercial production of compact cars in October 1992. Investment has totalled \$260 million by 1997 . Then a further \$146 million has been invested to produce a new small car, jointly developed with GM, but assembled separately under Suzuki and Opel badges in Esztergom and Gliwice, Poland, respectively. The Suzuki version is called Wagon $\mathrm{R}+$, and its production is commenced in January 2000. The other new model, called Ignis, was introduced in April 2003. It also means, that output will reach 100 thousand units a year. Diesel engines were also added to the product lines in November 2003. ${ }^{16}$

Opel Hungary Vehicle Manufacturing Ltd. opened the other Hungarian car assembly plant and an engine factory in a customs-free zone at Szentgotthárd, close to the Austrian border, in 1992, too. Initially GM Opel had invested over DM400 million. Opel Astras were produced in Hungary until December 1998.

As for the engine factory, its original capacity had been doubled to 460,000 units a year (i.e. around one-fourth of the total European production of Opel), and cylinder heads had also been added to the product lines due to further investment projects completed by 1996, worth of DM47 million, and DM210 million, respectively. Actual output primarily depends on demand for Opel models in Western Europe as the vast majority of production had been exported to Opel assembly plants even in until 1998 (when cars were assembled in Szentgotthárd), and $100 \%$ is exported since then.

A third car producer joined in 1998. Originally Audi AG has invested in Hungary in a new engine manufacturing plant, its first 100 per cent-owned manufacturing base outside Germany. Audi Hungaria Motor Kft (AHM), located in Győr, western Hungary, was opened in October 1994. Two new sport models, TT Coupé and Roadster have been assembled since April 1998, and July 1999, respectively, at AHM. A third model, A3 was added in 2001. Output has been increased in several steps, and further engine components have also been added to the product lines.

\subsubsection{Industrial Structure}

Automotive industry recently has been radically re-structured due to a globally diffusing organisational innovation, often called lean production. One of the most important novel features of lean production, and surely the most relevant one from the point of view of this study, is the new way to arrange and manage the assembler-supplier relationships, in other words, the new set of values and goals behind it. Unlike in Fordist mass production, it is based on trust and the realisation of the importance of co-operative efforts. A wide range of information, therefore, is almost continuously exchanged among assemblers and suppliers so

\footnotetext{
${ }^{15}$ These confronting opinions are described in more detail, e.g., by Somai (1993) and Varga (1990).

${ }^{16}$ For more details on these 3 cases, see the separate report on companies.
} 
as to improve efficiency by joint efforts. Different forms of financial, managerial and technological assistance are also provided by the assembler. The key notion is co-operation, in contrast to trade secrecy and mistrust between 'enemies', that is, assembler and supplier, in the Fordist mass production paradigm, given their fierce price war. Borrowing analogies from game theory, suppliers and assemblers are engaged in a zero-sum game in Fordist mass production, while in lean production both of them are interested in, and working for, enlarging the 'cake', i.e. increasing profits to be distributed among them.

Another distinctive feature of the lean supply chain is its pyramid-like structure. In its original Japanese version, first-tier suppliers are tied to assembler(s) through ownership, usually with a minority stake, interlocking cross share-holdings and personnel links. Their tasks include not only manufacturing of certain parts and components but product design as well, either together with their assemblers or on their own. ${ }^{17}$ As for manufacturing of a given part, though, usually more than one suppliers are chosen, and hence they are competing for orders. Supply quota and target price, based on thorough, jointly conducted cost calculations and full exchange of all the relevant production and market information, are set in advance in multi-year contracts. ${ }^{18}$ Constant cost-cutting is not only anticipated, given learning effects, but deliberately planned, moreover, even fixed in the supply contract. Extra savings, stemming from further improvements achieved by suppliers, however, can be retained as profits, and thus incentives for additional cost-reducing innovations are built in into the system. Suppliers' performance is regularly evaluated using multiple criteria such as quality, design, delivery and price. Supply quota, and thus profits, are awarded among suppliers according to the result of these evaluations.

First-tier suppliers have also built their network, usually consisting of 20-60 firms. These second-tier suppliers, in turn, rely on thousands of small and medium-sized enterprises, producing basically simple, labour-intensive products given their wage advantages compared to larger firms.

These general trends have had significant impacts in Hungary, too. The car assemblers follow their own version of the lean production paradigm. ${ }^{19}$ A number of foreign-owned T1 suppliers have also set up plants in Hungary, either via green-field plants, or by taking over Hungarian firms. Most of the indigenous companies, however, are T2 and T3 suppliers, with the exception of Rába.

Concentration ratios can be easily calculated by the Central Statistical Office (CSO), but funds have not been made available to this project to commission the CSO to conduct those computations. The industrial structure, therefore, can only be characterised in a qualitative manner.

\footnotetext{
${ }^{17}$ In the latter case they might well work with other firms and various R\&D institutes, of course. The point is, that the assembler only defines the main parameters of a given part or component, e.g. its size and required technical performance, and leaves the whole design process to its supplier.

${ }^{18}$ In sharp contrast with the short-term contracts in the Fordist mass production system, the time span of these contracts often extends to the entire model life (what is in most cases considerably shorter than in Fordist mass production, though).

${ }^{19}$ For more details, see the separate company reports.
} 


\subsection{4. $\quad$ Key Business Players and Ownership Patterns}

Some of the key business players are characterised in the separate company reports. As for the other ones, it is worth classifying them by their ownership. A wide variety of ownership forms can be observed.

\section{A) Dominant Foreign Ownership}

A.1 Green-field investments with 100 per cent foreign ownership. For the purpose of further analysis, it is useful to identify two sub-sets in this group:

A.1.1 Subsidiaries of car manufacturers: AUDI Hungaria Motor Kft., Visteon Hungary Kft (Ford), Opel Hungary

A.1.2 Subsidiaries of component manufacturers: e.g. Continental Teves (ITT Automotive Hungary before 1998), Lear (formerly United Technologies Automotive Hungary), Denso, Hydro Aluminium Györ Kft (previously VAW), Michels Kabel, Keiper-Recaro

A.2 'Brown-field' investments: former state-owned companies privatised by foreign investors, e.g. Knorr-Bremse, (Delco) Remy, ZF

B) Dominant Hungarian Ownership

\section{B.1 State-owned companies}

B.2 Privatised former state-owned companies: ${ }^{20}$ e.g. Bakony Müvek Rt., MMG Automatika Rt., Perion Akkumulátorgyár Rt.

B.3 Private companies, i.e. firms established by Hungarian entrepreneurs, e.g. ABF Bowdentechnika Kft

B.4 Joint ventures with dominant Hungarian private ownership, e.g. RATIPUR Car Equipment Co.

Individual companies can be relatively easily classified using these categories, although some companies might have started with green-field sites and taken over existing plants as a brown-field investment at a later stage as they extended their activities in Hungary - or the other way around, e.g. Bosch. As for a more rigorous quantitative analysis at a sectoral level, however, a number of methodological problems arise. First, it is needless to stress that ownership changes have been quite frequent in these sectors, especially until the late 1990s, and hence the overall picture, i.e. the ratio of different ownership forms, has been constantly changing. Therefore, from the point of view of economic analysis, it is a 'moving target'.

Second, given the lack of readily available statistics, it is not possible to precisely establish the ratio of private and state ownership. While seven distinct types of owners are recognised in the Hungarian statistics, namely the state, municipalities, domestic individuals, domestic corporations, ESOP, foreigners and co-operatives, published statistics only provide figures on state-owned and foreign-owned equity. Moreover, one category of ownership - namely 'domestic corporations', that is, share holding and limited liability companies - does not distinguish private and state ownership. ${ }^{21}$ Bearing in mind these methodological limitations,

\footnotetext{
${ }^{20}$ Privatisation has been usually conducted as a combination of ESOP (employee stock ownership programme) and MBO (management buy-out) projects. In some cases it has only been partial, i.e. a certain share of state ownership has been retained, especially in the first stage of privatisation.

21 Therefore an apparently legitimate formula, assuming that the municipality-owned assets are almost negligible, and thus the ratio of private ownership equals 100\% minus state ownership minus 2-6\% for municipality stakes, would lead to deceptive results.
} 
available statistics do suggest a dominant share of private (in particular foreign) ownership in both sectors. Data are presented separately for two different periods, namely 1992-1997, and 1998-2003, for methodological reasons (see Tables 4.8-4.11).

Table 4.8: Ownership changes in the manufacture of electrical automotive components (31.61), 1992-1997

\begin{tabular}{lrrrrrr}
\hline & 1992 & 1993 & 1994 & 1995 & 1996 & 1997 \\
\hline Equity (m HUF) & $2,065.8$ & 832.6 & 842.7 & 918.4 & $9,624.0$ & $2,569.6$ \\
Of which: foreign ownership & 121.1 & 166.5 & 276.2 & 505.4 & $9,282.7$ & $2,200.0$ \\
State ownership & $1,537.2$ & 154.0 & 154.0 & 15.0 & 15.1 & 13.2 \\
Share of foreign ownership (\%) & 5.9 & 20.0 & 32.8 & 55.0 & 96.5 & 85.6 \\
\hline
\end{tabular}

Note: Only double-book-keeping companies are included

Source: Ministry of Industry and Trade and author's calculations

Table 4.9: Ownership changes in the manufacture of electrical automotive components (31.61), 1998-2003

\begin{tabular}{lrrrrrr}
\hline & 1998 & 1999 & 2000 & 2001 & 2002 & 2003 \\
\hline Equity (m HUF) & 14,968 & 16,525 & 23,442 & 28,421 & 24,613 & 37,666 \\
$\begin{array}{l}\text { of which: state (including } \\
\text { municipalities) }\end{array}$ & 0 & 0 & 0 & 0 & 0 & 3 \\
$\quad$ foreign & 12,222 & 13,067 & 19,540 & 24,360 & 20,536 & 33,382 \\
Share of foreign ownership (\%) & 81.7 & 79.1 & 83.4 & 85.7 & 83.4 & 88,6 \\
\hline
\end{tabular}

Source: Ecostat and author's calculation

Table 4.10: Ownership changes in the manufacture of parts and components for motor vehicles (34.30), 1992-1997

\begin{tabular}{lrrrrrr}
\hline & 1992 & 1993 & 1994 & 1995 & 1996 & 1997 \\
\hline Equity (m HUF) & $19,657.8$ & $21,831.8$ & $22,400.9$ & $23,598.9$ & $27,478.5$ & $40,173.6$ \\
Of which: foreign ownership & $2,517.8$ & $3,348.1$ & $4,029.3$ & $6,080.8$ & $8,669.8$ & $22,246.8$ \\
state ownership & $9,130.3$ & $9,051.4$ & $7,190.5$ & $5,434.6$ & $4,389.6$ & 338.0 \\
Share of foreign ownership (\%) & 12.8 & 15.3 & 18.0 & 25.8 & 31.6 & 55.4 \\
\hline
\end{tabular}

Note: Only double-book-keeping companies are included

Source: Ministry of Industry and Trade and author's calculations

Table 4.11: Ownership changes in the manufacture of parts and components for motor vehicles (34.30), 1998-2003

\begin{tabular}{lrrrrrr}
\hline & 1998 & 1999 & 2000 & 2001 & 2002 & 2003 \\
\hline Equity (m HUF) & 60,631 & 69,396 & 69,536 & 75,634 & 57,374 & 63,522 \\
Of which: state (including & & & & & 804 & 804 \\
municipalities) & 445 & 445 & 445 & 445 & & \\
$\quad$ foreign & 45,048 & 51,336 & 53,099 & 58,622 & 41,272 & 46,948 \\
Share of foreign ownership (\%) & 74.3 & 74.0 & 76.4 & 77.5 & 71.9 & 73,9 \\
\hline
\end{tabular}

Source: Ecostat and author's calculation 


\subsubsection{Patterns of Competition}

Although car assemblers, first- (T1), second- (T2) and third-tier (T3) suppliers are all necessary to constitute a production network, and in the end of the day they all share the network's destiny, they have different responsibilities in the division of labour in a given network, and they have to face different type of risks. Therefore, it is necessary to analyse them somewhat separately - but also keeping in mind the strong and close ties among them.

\subsubsection{Evolving strategies for car-makers to improve competitiveness}

Car-makers have to face a strong competition and mature markets in their traditional area of operation. Moreover, they are not - and in the foreseeable future most likely they will not be - in the position to expect a 'breakthrough' from this trap relying on any technological breakthrough. Thus they have to devise and implement other strategies:

- cutting costs in order to keep existing markets via offering lower prices,

- introducing new features, offering new functions (e.g. safety, comfort, global positioning systems, recycling) as well as improving reliability and fuel economy,

- creating new market segments in long-established, mature, markets by introducing e.g. sports models, four-wheel-drive cars, light trucks, minivans,

- finding new markets with new customers and ideally less intense competition,

- introducing organisational innovations to improve flexibility, shorten lead and delivery times, ${ }^{22}$

- customising mass-produced models, that is, offering the opportunity to buyers to 'design' their own car, using, of course, a set of standardised components. ${ }^{23}$

In short, price is still the bottom line of competitiveness in the car industry, yet many more characteristics have become a must for car-makers. Two of the above strategic elements are the most relevant from a Central and Eastern European point of view: cost-cutting and entering new markets.

Cost-cutting is a decisive element of basically all car-makers' strategy. That is why they set up their new plants in South America, South-East Asia as well as Central and Eastern Europe (CEE), where production costs are usually lower than in their established bases, and for the same reason they encourage their suppliers to follow them, and/or to find other ways to offer cheaper parts and components. Another way of cost-cutting is to introduce improved production equipment and vehicle components (that is, incremental technological innovations, as opposed to radical innovations) as well as more efficient production processes

\footnotetext{
${ }^{22}$ Lead times - once constituting a major competitive edge for Japanese carmakers - have become rather short, thanks to the introduction of lean production, where T1 suppliers are involved in the design of new models, and the so-called rugby approach is used - instead of the former 'relay' method - among the various departments involved in designing a new model. (Graves (1991), (1994)). This new phenomenon underlines the importance of organisational innovations, too.

${ }^{23}$ No doubt, it requires a great deal of flexibility in terms of manufacturing and logistics, and, in turn, might lead to longer delivery time and higher costs. Therefore organisational innovations, coming either from carmakers or T1 suppliers, are of crucial importance. Quite often, though, technological innovations are necessary preconditions of organisational innovations, e.g. improved flexibility obviously requires organisational innovations, which, in turn, usually necessitate an appropriate, customised new IT tool kit and/or improved production equipment.
} 
(organisational and managerial innovations). ${ }^{24}$ In the lean production paradigm - as opposed to the Fordist one - suppliers are important sources of innovations, and new products, processes and managerial techniques are spread quickly throughout the whole network (assembler, T1, T2 and T3 suppliers).

Emerging markets are also considered to be important because by definition they promise new buyers. Moreover, in the late 1980s CEE countries were fairly abandoned, that is, competition among car-makers was practically unknown, on the contrary, buyers had to 'compete' with each others and distributors for cars. Hence, most cars were rather obsolete in these countries, making people even more 'hungry' for new cars. In short, it seemed to be a Paradise for car-makers. However, this region has become crowded in a very short period of time because quite a few major W European, US and Asian companies have invested in production facilities. To make it worse, optimistic sales forecast have not materialised either, as most people cannot afford new cars, especially in the potentially largest markets, i.e. in CIS countries. The current crisis in SE Asia puts car-makers into an even more intense competition globally.

The three car-makers operating in Hungary apply different elements of the above strategic mix. Magyar Suzuki assembles small cars. In this segment, profit margins are rather low because the main competition axis is price. Suzuki also puts emphasis on fuel economy, and hence organises special rallies where the most economical drivers are awarded. From time to time small, special batches are produced to appeal to a certain customer group. New models have already been introduced to replace the outdated original model, and further ones are to be added to the product lines in the coming years. As they belong to the same segment, competitiveness is also based on price, as well as fuel economy; yet, design features play a more important role than in the 1990s.

Opel has decided to abandon car assembly in Hungary. Its new strategy is focusing on low cost manufacturing of high-tech, high-value-added components - engine components, engines and gearboxes - as well as low-cost, high-quality R\&D conducted in Hungary to help improve its overall competitiveness. In short, it is a global strategy with carefully planned division of labour among various Opel plants across countries.

AUDI Hungaria Motor, besides producing engines in large volumes for the entire VW group, assembles its two new sports models in Györ, aimed at serving a special market segment of the affluent young professionals, primarily in the Western European markets. In this segment, design - technical and aesthetic features - is the key element of the competition. Yet, price should be kept as low as possible, and flexibility is even more important than in the case of 'normal' cars because of seasonal cycles in demand. Hence, Hungary seems to be an ideal production base with skilled but cheap workers and flexible labour regulations compared to Germany.

\footnotetext{
${ }^{24}$ A successful concept of cost-cutting is the so-called platform strategy whereby the basic components of 3-5 models are shared, and thus economies of scales in producing those elements and product variety - that is, apparently different models serving different markets (or segments) - can be achieved simultaneously. This concept requires the introduction of a set of interrelated technological and organisational innovations.
} 


\subsubsection{Competitive strategies of suppliers}

T1 suppliers are increasingly similar to car assemblers in many respects, and thus they have to face a similar - competitive, global - environment. Reliable quality, continuous costcutting - with all its methods and prerequisites discussed above -, timely delivery, the ability to innovate and manage the rest of the supply chain are all indispensable for survival. Therefore, it is hardly possible to single out any distinctive, new competition axis. T2 and T3 suppliers, however, have less responsibilities, the main competition axis for them is price. Nonetheless, all of them should be able to maintain reliable quality and timely shipment of parts and introduce the technological and organisational innovations developed by assemblers or T1 suppliers.

These general observations apply to the Hungarian case, too. T1 suppliers - e.g. Continental Teves (former ITT), Knorr-Bremse, UTA, ZF - serve the global markets from their Hungarian production bases, only an almost negligible fraction of their output is shipped to the local car assembly plants. In the beginning, their primary concern was cost-cutting in the production phase. Gradually, however, they have recognised that Hungarian engineers and researchers at various $R \& D$ units can provide useful services for their internationalised $R \& D$ projects, too, at a rather low cost. Therefore, they have already set up their own, in-house R\&D units or decided to do so. Continental Teves is a somewhat exceptional case. Initially its small Hungarian R\&D unit mainly worked for the German subsidiary, not for the local one. Since 2001, however, it has been extended, and become responsible to develop sensor technologies at a European scale, and thus also works for the Hungarian subsidiaries. The other way is to 'delegate' Hungarian engineers into the parent company's global research teams. UTA, for example, has not opened an in-house R\&D unit, its engineers, however, are involved in a number of $R \& D$ projects run by various subsidiaries of the parent company. Sometimes they work abroad, at other times they work from Hungary, sending and receiving data electronically.

As for the intensity of competition in the local market, it should be taken into account that some 10-12 thousand parts and components are used to build a vehicle. To put it simply, an engine manufacturer, say, might account for a very large share of the sector's output, yet, it does not mean that it would dominate, say, a seat manufacturer, who, in turn, has a much smaller share of the sector's output.

As for a more qualitative overview, there is a strong competition in the automotive components manufacturing. Although some companies might have a relatively large domestic market share, e.g. in the case of axles, batteries, bearings or lighting, they also have to face a fierce competition in their export markets, and given the relatively small size of the Hungarian market as well as the importance of scale economies, they cannot avoid exporting the bulk of their output. The only exception is engine manufacturing: the combined capacity of Audi and Opel is around 2 million units a year, and thus it is a large enough market for their suppliers. That is why foreign foundries and machining companies are setting up their Hungarian operations (e.g. ADA, Pre-cast, Le Belier, Hydro [originally VAW] and Jung). In this case, there is strong competition for the 'domestic market'. The engines produced in Hungary, in turn, are shipped to the various car assembly plants of Audi, VW (including SEAT and Skoda) and GM Opel in Europe. 


\subsubsection{Production Networks: Sources of innovation}

Relying on a survey conducted in the mid-1990s, as well as on a series of interviews and case studies conducted in the late 1990s, and then in 2002-2004, two major lessons can be drawn. First, the Hungarian case confirms the general picture emerging from the literature, namely car assemblers and their T1 suppliers are the most important sources of innovation for the entire production network they coordinate. Second, some buyers, or their first-tier foreign suppliers, provide licences and know-how free of charge for T2 and T3 suppliers. The most important example was Magyar Suzuki in the 1990s (also offering various forms of financial assistance for tooling-up). This is the major element of an explanation to reconcile the apparent contradiction between the low level of expenditures on technology related activities and the introduction of relatively large number of new products and processes. ${ }^{25}$ In other cases, however, it is a prerequisite to buy certain licences or know-how, otherwise there is no business.

As already mentioned, Hungarian automotive suppliers have to adjust to a radically altered international and domestic environment (import liberalisation, loss of former markets, new players in Hungary, etc.). Thus, those who want to survive have also introduced new management techniques. The most important types of these innovations are total quality management and reliable cost accounting. Foreign partners usually provide technical assistance and training courses to facilitate the introduction of these techniques.

Managerial innovations can be analysed at a sectoral level, too, as opposed to individual company level. In the lean production system, first-tier suppliers assume a considerable part of responsibility for product development as well as for organising and managing the supply chain (logistics) as they build and supply sub-systems, rather than individual components. In other words, they are responsible for second-tier - and indirectly - for third-tier suppliers' performance, too. Thus, they also provide training, technical assistance to their suppliers to facilitate the introduction of an appropriate quality management, cost accounting, production and delivery systems, etc. More recently Western car-makers follow this way, i.e. they cut the number of their first-tier (direct) suppliers and give them more responsibility.

This 'tiering' has hardly occurred in Hungary until the early 1990s. One should not be surprised, however, as most Hungarian companies have supplied simple, individual parts, rather than complex sub-systems to their customers. Moreover, they have not been involved in product development, either, as the models produced by Audi Hungaria, Magyar Suzuki and Opel Hungary had been designed before their assembly started in Hungary. One should take into account that it was a relatively new concept even for the Western European managers until the mid-1990s. A detailed analysis of the British automotive industry in that period also claimed, that British managers had a long way to go, too, on the road leading towards 'tiering':

By collaboration, the first tier of suppliers may help to develop the value chain of vehicle manufacturer or the progress and competitiveness of a national or regional industry. There has been little such activity so far: indeed the major UK suppliers could more accurately be called an unconnected group, rather than a first tier. (DTI and SMMT (1994), p. 11)

Their Hungarian counter-parts, however, first had to learn even the 'simple' techniques of market economy, too, not only these new principles of lean supply. Moreover, in the

\footnotetext{
${ }^{25}$ Another major factor is that these innovations represent low- or mid-tech technologies, rather than high-tech ones, and hence financially they are less demanding.
} 
meantime they also had to struggle for survival. More recently, however, some preliminary signs of the emerging new supply system can be observed in certain cases. As subsidiaries of major Western component manufacturers are taking on board more Hungarian suppliers, a more pronounced 'tiering' can be observed. For example, ZF has developed a supplier park around its plant in Eger. In short, T1 suppliers assume responsibility in organising the supply chain in Hungary, too, following the global patterns.

\subsection{IMPACT OF R\&D AND INNOVATION}

No studies are readily available on the impacts of $R \& D$ in these sectors. As already emphasised, though, technological and organisational innovations, brought in by foreign firms, and diffused to their indigenous suppliers, have played a major role in re-structuring these sectors. The following sub-section, relying on available data at sub-sector level, characterise these fundamental changes, reflected in various performance indicators. It is assumed that innovation has contributed to improved performance to a significant extent.

Sales have significantly increased in both sectors, analysed in detail in this report: the 2003 output of electrical automotive components was around 13 times as much as in 1992, and the other sector - from a much higher absolute level - grew almost 7 times bigger than in 1992, using constant [1992] price data. ${ }^{26}$ (For current price data, see Tables 4.12-4.13.) The export intensity of these sectors is also worth noting, particularly in the case of the electrical automotive components (3161), where the ratio of exports to sales further increased from an already high level: from 58 per cent in 1992 to $90.2 \%$ in 2003. Thus, it can be established beyond doubt that these companies face a fierce competition: given the globalised nature of the automotive industry and the liberal import regime there is a strong rivalry in their domestic market, and they also face harsh competition in their export markets, where the bulk of their output is shipped. Moreover, their financial performance has significantly improved, too, i.e. they are not 'buying' export markets at the expense of their profits. ${ }^{27}$ Thus, their impressive growth in 1992-2003 is even more remarkable. Figures indicate that the underlying factor of their success is improved labour productivity: measured as value added per employees, in real terms it has increased by 2.5 times in the electrical automotive components sector (31.61), and doubled in the other one (34.30). ${ }^{28}$ Another 'proxy' for labour productivity can be sales per employees; then one can observe a 3.6-fold increase in the case of electrical automotive equipment, and a 3.5-fold improvement in the case of automotive components (using constant price figures). Case studies, conducted a few years ago, suggest that this noteworthy improvement is thanks to the introduction of new processes and management techniques, and in a number of cases due to the modernisation of equipment,

\footnotetext{
${ }^{26}$ Constant 1992 prices have been calculated by taking into account producer price indices for these two sectors, or for some years the nearest available ones, e.g. indices for the sector 316, instead of the ones for 3161.

${ }^{27}$ Yet, the profitability of the components sector (3430) - measured as net profits/sales - was rather low until 1997, and fluctuating in the range of 8.6-10.6 per cent since 1998. The other sector (3161) is rather volatile in this respect: it was in the red until 1995, then fared quite well in 1996-2000 (with a net profit/sales ratio between 6.9 and 10.7 per cent), and performing significantly below that level since 2000 (e.g. a 4.6 per cent profitability in 2003).

${ }^{28}$ GDP implicit price indices have been used to 'deflate' current price value added figures. Of course, only an indication of real term value added figures can be calculated in this way; a proper method would be to use GDP deflators at a sectoral level, but those indices are not available. That is why another indicator is also used here: sales per employees, using sectoral producer price indices to calculate real term sales figures.
} 
too, reflected in the increase of assets (by around 7 times, in both sectors, using historical asset pricing). 
Table 4.12: Manufacture of electrical automotive components (31.61), 1992-2003

\begin{tabular}{|c|c|c|c|c|c|c|c|c|c|c|c|c|c|}
\hline & 1992 & 1993 & 1994 & 1995 & 1996 & 1997 & 1998 & 1999 & 2000 & 2001 & 2002 & 2003 & 2003/1992* \\
\hline Number of companies & 32 & 39 & 41 & 42 & 49 & 57 & 61 & 62 & 60 & 69 & 72 & 78 & $243.8 \%$ \\
\hline Sales $(\mathrm{m} \mathrm{HUF} * *)$ & 8,208 & 16,408 & 27,655 & 38,578 & 63,539 & 95,486 & 133,741 & 191,706 & 236,945 & 250,648 & 212,794 & 280,396 & $3416.1 \%$ \\
\hline of which: exports (m HUF) & 4,758 & 4,983 & 16,923 & 28,150 & 54,588 & 85,367 & 107,173 & 155,498 & 216,253 & 226,586 & 190,115 & 252,983 & $5317.0 \%$ \\
\hline Exports/sales $(\%)$ & 58.0 & 30.4 & 61.2 & 73.0 & 85.9 & 89.4 & 80.1 & 81.1 & 91.3 & 90.4 & 89.3 & 90.2 & $155.6 \%$ \\
\hline Employment (average, heads) & 5,658 & 6,464 & 7,070 & 7,619 & 10,667 & 13,189 & 14,888 & 16,622 & 23,630 & 17,605 & 19,409 & 20,033 & $354.1 \%$ \\
\hline Pre-tax profits (m HUF) & $-1,070$ & -558 & $-1,405$ & $-1,527$ & 4,815 & 9,243 & 10,050 & 13,845 & 26,395 & 16,713 & 9,870 & 18,307 & $380.2 \%$ \\
\hline Net profits (m HUF) & $-1,140$ & -651 & $-1,487$ & $-1,625$ & 4,512 & 9,100 & 9,661 & 13,147 & 25,386 & 15,506 & 8,450 & 13,037 & $288.9 \%$ \\
\hline Assets (m HUF) & 8,218 & 11,628 & 12,113 & 14,730 & 21,638 & 28,916 & 35,790 & 44,243 & 52,640 & 65,207 & 46,185 & 60,066 & $730.9 \%$ \\
\hline Value added (m HUF) & 2,098 & 4,466 & 7,634 & 8,785 & 19,980 & 32,565 & 38,802 & 49,968 & 59,726 & 62,848 & 60,311 & 80,163 & $3820.9 \%$ \\
\hline Sales/employee (m HUF) & 1.5 & 2.5 & 3.9 & 5.1 & 6.0 & 7.2 & 9.0 & 11.5 & 10.0 & 14.2 & 11.0 & 14.0 & $964.8 \%$ \\
\hline Value added/employee (000 HUF) & 370.8 & 690.9 & $1,079.8$ & $1,153.0$ & $1,873.1$ & $2,469.1$ & $2,606.3$ & $3,006.1$ & $2,527.5$ & $3,569.9$ & $3,107.4$ & $4,001.5$ & $1079.2 \%$ \\
\hline Net profits/sales $(\%)$ & -13.9 & -4.0 & -5.4 & -4.2 & 7.1 & 9.5 & 7.2 & 6.9 & 10.7 & 6.2 & 4.0 & 4.6 & $65.5 \%$ \\
\hline Value added/sales (\%) & 25.6 & 27.2 & 27.6 & 22.8 & 31.4 & 34.1 & 29.0 & 26.1 & 25.2 & 25.1 & 28.3 & 28.6 & $111.8 \%$ \\
\hline
\end{tabular}

Source: Ecostat and author's calculation

* In case the 1992 data are negative, 1996 is used as a base year

** Current prices, throughout the table

Table 4.13: Manufacture of parts and accessories for motor vehicles and their engines (34.30), 1992-2003

\begin{tabular}{|c|c|c|c|c|c|c|c|c|c|c|c|c|c|}
\hline & 1992 & 1993 & 1994 & 1995 & 1996 & 1997 & 1998 & 1999 & 2000 & 2001 & 2002 & 2003 & 2003/1992* \\
\hline Number of companies & 88 & 116 & 118 & 132 & 137 & 155 & 165 & 173 & 178 & 180 & 176 & 179 & $203.4 \%$ \\
\hline Sales (m HUF**) & 24,335 & 32,272 & 40,949 & 62,217 & 85,814 & 146,793 & 218,670 & 273,930 & 358,961 & 412,528 & 398,180 & 522,915 & $2148.8 \%$ \\
\hline of which: exports (m HUF) & 14,053 & 17,689 & 23,038 & 40,377 & 56,655 & 105,615 & 172,223 & 223,116 & 309,087 & 331,985 & 346,287 & 445,015 & $3166.7 \%$ \\
\hline Exports/sales $(\%)$ & 57.7 & 54.8 & 56.3 & 64.9 & 66.0 & 71.9 & 78.8 & 81.5 & 86.1 & 80.5 & 87.0 & $85.1 \%$ & $147.4 \%$ \\
\hline Employment (average, heads) & 14,238 & 14,914 & 15,091 & 15,490 & 16,574 & 19,485 & 21,753 & 22,079 & 22,436 & 24,720 & 22,189 & 26,673 & $187.3 \%$ \\
\hline Pre-tax profits (m HUF) & -77 & 582 & 1,014 & 3,292 & 3,107 & 8,743 & 23,989 & 31,231 & 41,907 & 39,470 & 41,059 & 58,772 & $10098.3 \%$ \\
\hline Net profits (m HUF) & -154 & 318 & 889 & 3,030 & 2,751 & 8,303 & 23,098 & 27,795 & 37,402 & 35,471 & 36,914 & 49,879 & $15685.2 \%$ \\
\hline Assets (m HUF) & 24,040 & 24,891 & 26,133 & 28,310 & 48,116 & 70,095 & 93,983 & 105,267 & 117,025 & 149,364 & 141,699 & 169,020 & $703.1 \%$ \\
\hline Value added (m HUF) & 9,243 & 11,523 & 14,631 & 20,123 & 24,520 & 40,486 & 62,089 & 79,961 & 102,648 & 117,089 & 114,445 & 147,709 & $1598.1 \%$ \\
\hline Sales/employee (m HUF) & 1.7 & 2.2 & 2.7 & 4.0 & 5.2 & 7.5 & 10.1 & 12.4 & 16.0 & 16.7 & 17.9 & 19.6 & $1147.0 \%$ \\
\hline Value added/employee (000 HUF) & 649.2 & 772.6 & 969.5 & $1,299.1$ & $1,479.4$ & $2,077.8$ & $2,854.3$ & $3,621.6$ & $4,575.1$ & $4,736.6$ & $5,157.7$ & $5,537.8$ & $853.0 \%$ \\
\hline Net profits/sales $(\%)$ & -0.6 & 1.0 & 2.2 & 4.9 & 3.2 & 5.7 & 10.6 & 10.1 & 10.4 & 8.6 & 9.3 & $9.5 \%$ & $968.0 \%$ \\
\hline Value added/sales (\%) & 38.0 & 35.7 & 35.7 & 32.3 & 28.6 & 27.6 & 28.4 & 29.2 & 28.6 & 28.4 & 28.7 & $28.2 \%$ & $74.4 \%$ \\
\hline
\end{tabular}

Source: Ecostat and author's calculation

* In case the 1992 data are negative, 1993 is used as a base year

** Current prices, throughout the table 


\subsection{SUMMARY AND CONCLUSIONS}

Automotive investment activities across borders have significantly intensified in recent years in an attempt to cut costs via re-location of production, and to get closer to the ultimate customers in emerging markets. Central Europe, the immediate neighbourhood of Hungary is no exception either: the region has moved again onto the global stage. Almost all major automotive groups, except some leading Japanese automotive firms - Nissan and Mitsubishi - have already set up their operations in Central Europe. These intensified investment activities have had crucial bearings on the Hungarian automotive industry: after a half-acentury interval - imposed by the CMEA-wide division of labour - car production has reemerged in Hungary in the early 1990s. Suppliers have also invested heavily in Hungary. Moreover, their motivation has not been simply to follow car assemblers - to serve them from nearby plants -, on the contrary, this is only a minor part of the explanation. Their principal reason for setting up subsidiaries - either green- or brown-field plants - in Hungary has also been cost-cutting. The only major local clients for them are not car assemblers but the engine manufacturing plants of Audi and GM Opel, hence the vast majority of their output is exported.

These strategic moves have radically re-structured the indigenous suppliers, too. In other words, transition has been accomplished in this sector. Some suppliers have been taken over by foreign firms, while others have been integrated into the global networks of major automotive groups as subcontractors. In both cases new products, processes and management techniques have been introduced quite rapidly. Data clearly show that components manufacturing is much more important than car assembly, even from a somewhat narrowminded macroeconomic point of view: turnover, employment and exports figures are significantly larger in the former sector than in the latter. Taking a more general perspective, that is, industrial development and competitiveness, suppliers, and particularly the networking activities of T1 suppliers, are still more substantial: it is mainly due to them that new technologies and organisational innovations are diffusing fast and widely in Hungary. From a policy point of view, however, it is necessary to take into account the differences between various types of suppliers. Therefore, a taxonomy has been developed.

Foreign investors have chosen Hungary partly because skilled labour is relatively cheap around one seventh of the German wages. Yet, had wages alone been sufficient to improve competitiveness, Western automotive firms would have gone to Ukraine and other CIS countries, where labour is even significantly cheaper. In fact, what really matters is that Hungarian workers are highly skilled, due to a German-type vocational training system in place for many decades. As quality, reliability and productivity are all major concerns for automotive companies, there is no need to emphasise the importance of skills and experience. In short, the real advantage is the excellence of workers coupled with low wages. Further, foreign companies find flexible employment conditions in Hungary; shift work and overtime working is a commonplace, offering investors a production regime to suit their needs. Grants and concessions offered by the government - to ease the annoying shortage of cars and facilitate industrial re-structuring - has also been instrumental to attract foreign investors.

A brief comparison of production paradigms has also shown the crucial importance of innovation, R\&D and engineering skills. Given the excellence of the Hungarian higher education system, there is no shortage of engineers endowed with these skills and knowledge. Interviews suggest emerging co-operation between automotive firms, on the one hand, and university departments as well as other R\&D units, on the other. More recently, some foreign 
investors - e.g. Audi, GM Opel, ITT, Knorr-Bremse and ZF - have also realised the worldclass knowledge of Hungarian scientists and engineers, and they are setting up either their inhouse R\&D units or joint research groups with universities. Again, besides professional excellence, there is a considerable cost advantage in this field, too. Further, in the second half of the 1990s, R\&D schemes were also applied to foster innovation activities in the automotive industry, and a new one was launched in 2006.

In sum, the successful re-structuring of the Hungarian automotive industry is not only due to some 'push' factors, i.e. the fierce competition among automotive companies and hence the pursuit of cost-cutting via re-location of their production, but it also thanks to 'pull' factors, i.e. the attractions of the Hungarian economic environment, broadly defined. Given the ever changing, and global, nature of the automotive industry, no country can be complacent, on the contrary, continuously renewed, concerted efforts and well-devised policy measures are needed to achieve further results.

\subsection{REFERENCES}

Abo, T. (1992): Japanese Motor Vehicle Technologies Abroad in the 1980s. In D. J. Jeremy (ed.) The Transfer of International Technology: Europe, Japan and the USA in the twentieth century, Aldershot: Edward Elgar

Bauer, T., Patkós, A., Soós, K.A., Tárnok, É. and Vince, P. (1980): Jármüprogram és gazdaságirányítás (Vehicle Programme and Central Economic Control), mimeo, Budapest: Institute of Economics, Hungarian Academy of Sciences

Bauer, T., and K.A. Soós (1980): Kényszerpályák hálójában - Vállalatközi kapcsolatok és müszaki fejlesztés a jármüiparban (Forced Paths: Inter-enterprise relationships and technical development in the automotive industry), in Tardos, M. (ed.) (1980), pp. 149-84

Berend, T. I., and Ránki, Gy. (1955): Magyarország gyáripara 1900-1914 (Hungary’s Industry in 1910-1914), Budapest: Szikra

Berend, T. I., and Ránki, Gy. (1958): Magyarország gyáripara a második világháború előtt és a háború időszakában, 1933-1944 (Hungary's Industry before and during World War II, 1933-1944), Budapest: Akadémiai Kiadó

Bongardt, A. (1992): The EC Automotive Industry: Supply relations in context, in H.W. de Jong (ed.): The Structure of European Industry, 3rd edition, Dordrecht: Kluwer Academic Publishers

Boyer, R., Charron, E., Jürgens, U. and Tolliday, S. (eds) (1998): Between Imitation and Innovation: The Transfer of Hybridization of Productive Models in the International Automobile Industry, Oxford: Oxford University Press

Boyer, R. and Freyssenet, M. (2002): The productive models: the conditions of profitability, Basingstoke: Palgrave Macmillan

Clark, K.B., Fujimoto, T. and Chew, W.B. (1987): Product Development in the World Auto Industry, Brookings Paper on Economic Activity, 3: 729-771

DTI and SMMT (1994): A Review of the Relationships between Vehicle Manufacturers and Suppliers, report on the DTI/SMMT Automotive Components Initiative

Edquist, C. (ed.) (1997): Systems of Innovations: Technologies, institutions and organizations, London: Pinter

Freeman, C. (1992): Formal Scientific and Technical Institutions in the National System of Innovation, in: B-A Lundvall (ed.): National Systems of Innovation: Towards a theory of innovation and interactive learning, London: Pinter Publishers 
Freyssenet, M, Mair, A., Shimuzu, K. and Volpato, G. (eds) (2000): One Best Way? Trajectories and Industrial Models of the World's Automobile Producers, Oxford: Oxford University Press

Frigant, V. and Lung, Y. (2002): Geographical proximity and supplying relationships in modular production, International Journal of Urban and Regional Research, 26(4): 742755

Graves, A. (1991): Globalisation of the automobile industry: the challenge for Europe, in C. Freeman, M. Sharp and W. Walker (eds): Technology and the Future of Europe, (pp. 261280), London: Pinter Publishers

Graves, A. (1994): Innovation in a Globalizing Industry: The case of automobiles, in M. Dodgson and R. Rothwell (eds): The Handbook of Industrial Innovation, (pp. 213-231), Edward Elgar: Aldershot

Hara, R. (1993): Strategic Issues for Japan's Auto Industry, NRI Quarterly, 1994(Spring): 5881

Havas, A. (1995): Hungarian Car Parts Industry at a Cross-Roads: Fordism versus lean production, Emergo, 2(3): 33-55

Havas, A. (1997): Foreign Direct Investment and Intra-Industry Trade: The case of automotive industry in Central Europe, in: D. Dyker (ed.): The Technology of Transition, (pp. 211-240), Budapest: Central European University Press

Havas, A. (2000a): Local, regional and global production networks: re-integration of the Hungarian automotive industry, in: C. von Hirschhausen and J. Bitzer (eds): The Globalization of Industry and Innovation in Eastern Europe - From Post-socialist Restructuring to International Competitiveness, (pp. 95-127), Cheltenham: Edward Elgar

Havas, A. (2000b): Changing Patterns of Inter- and Intra-Regional Division of Labour: Central Europe's long and winding road, in: J. Humphrey, Y. Lecler and M. Sergio Salerno (eds): Global Strategies and Local Realities: The Auto Industry in Emerging Markets, (pp. 234-262), Basingstoke: Macmillan

Havas, A. (2003): A multinacionális jármüipari vállalatok és a magyar alkatrész-gyártók közötti technológiai és beszállítói kapcsolatok (Multinational Automotive Companies and their Hungarian Suppliers: Technological links), mimeo, Budapest: Institute of Economics, Hungarian Academy of Sciences

Havas, A. (2004): Central Europe as an Emerging Automotive Space, Cursos de veranos, Pamplona, 20-22 July 2004

Helper, S. (1991): Strategy and Irreversibility in Supplier Relations: The case of the U.S. automobile industry, Business History Review, 65(Winter): 781-824.

Helper, S. (1993): An exit-voice analysis of supplier relations: the case of US automobile industry, in: Grabher, G. (ed.): The Embedded Firm, (pp. 141-160), London: Routledge

Hollanders, H. and Arundel, A. [2005]: European Sector Innovation Scoreboards, European TrendChart on Innovation, available at: www.trenchart.cordis.lu

Hudson, R. and David, S. (1992): Just-in-Time Production and the European Automotive Components Industry, Discussion Paper No. 10, Change in the Automobile Industry: An international comparison

Humphrey, J., Lecler, Y. and Salerno, M. (eds) (2000): Global Strategies and Local Realities: The Auto Industry in Emerging Markets, Basingstoke: Macmillan

Jones, D. T. (1989): Corporate strategy and technology in the world automobile industry, in Dodgson, M. (ed.): Technology Strategy and the Firm: Management and public policy, (pp. 11-24), London: Longman 
Jones, D. T. (1999): The car industry, in: Dyker, D (ed.): The European Economy, (pp. 307325), Harlow: Addison Wesley Longman

Lamming, R. (1993): Beyond Partnership: Strategies for innovation and lean supply, New York: Prentice Hall

Lung, Y., Chanaron, J.J., Fujimoto, T., Raff, D. (eds) (1999): Coping with Variety: Product Variety and Production organization in the World Automobile Industry, Aldershot: Ashgate

Malerba, F. (2002): Sectoral systems of innovation and production, Research Policy, 31: 247264.

OECD (1992): The Automotive Parts Industry, in: Globalisation of Industrial Activities: Four case studies, Paris

Pavlinek, P. (2002a): Restructuring the Central and Eastern European automobile industry: Legacies, trends, and effects of foreign direct investment, Post-Soviet Geography and Economics, 43 (1): 41-77

Pavlinek, P. (2002b): Transformation of the Central and East European passenger car industry: selective peripheral integration through foreign direct investment, Environment and Planning A, 34 (9): 1685-1709

Richardson, J. (1993): Parallel Sourcing and Supplier Performance in the Japanese Automobile Industry, Strategic Management Journal, (14): 339-350

Sako, M., Lamming, R. and Helper, S. R. (1995): Supplier Relations in the UK Car Industry: Comparisons with Europe, Japan and the US, report prepared for the DTI, January

Sako, M. (1997): Emergent Dualism in the UK Automotive Industry: Should we be concerned?, mimeo, London: LSE

Sako, M. (1998): Does Trust Improve Business Performance?, in: Lane, Christel, Reinhard Bachmann (eds): Trust Within and Between Organizations: Conceptual Issues and Empirical Applications, Oxford: Oxford University Press

Sako, M. and Helper, S. (1998): Determinants of trust in supplier relations: Evidence from the automotive industry in Japan and the United States, Journal of Economic Behavior and Organization, 34: 387-417

Shapiro, H. (1991): Determinants of Firm Entry into the Brazilian Automobile Manufacturing Industry, 1956-1968, Business History Review, 65(Winter): 877-947

Somai, M. (1993): The car industry and motorization in Hungary, Working Paper No. 26, Institute for World Economics, Hungarian Academy of Sciences, Budapest

Somai, M. (1996a): Autóipari beruházások: Piacfoglalás négy keréken, Figyelő, April 11, 1996: $51-53$

Somai, M. (1996b): Két autóipari óriás Magyarországon: az Opel és az Audi, Ipargazdasági Szemle, Struktúrák, Szervezetek, Stratégiák, 26(3-4): 94-105

Somai, M. (2000): Autóipar Magyarországon: a személyautó- és autóalkatrész-gyártás nemzetközi „beágyazottsága” és integráló hatása hazai háttériparra, MTA VKI Mühelytanulmányok No.28

Soós, K. A. (1980): Műszaki színvonal és gazdaságosság: Beruházási döntés egy központi fejlesztési program keretében (Technical Level and Profitability: Investment decision in the framework of a central development programme), in Tardos, M. (ed.) (1980), pp. 28594

Sturgeon, T. J. and Florida, R. (2000): Globalization and Jobs in the Automotive Industry, final report to the Alfred P. Sloan Foundation, MIT IPC Globalization Working Paper 01003 
Swain, A. (1992): Eastern Europe and the Global Strategies of Automobile Producers, Change in the Automobile Industry: An international comparison, Discussion Paper No. 11, University of Durham

Swain, A. (1998): Governing the workplace: The workplace and regional development implications of automotive foreign direct investment in Hungary, Regional Studies, 32(7): 653-671

Takeishi, A. (2001): Bridging inter- and intra-firm boundaries: Management of supplier involvement in automobile product development, Strategic Management Journal, 22: 403433

Tardos, M. (ed.) (1980): Vállalati magatartás - vállalati környezet (Enterprises’ Behaviour Enterprises’ Environment), Budapest: Közgazdasági és Jogi Könyvkiadó

Tárnok, É. and Vince, P. (1980): Szervezett bizonytalanság (Organised Uncertainty), in Tardos, M. (ed.) (1980), (pp. 219-54)

Varga, Gy. (1990): Mibe szállunk be? - Magyar gépkocsi-ipar (Strategic Options for the Hungarian Automotive Industry), Figyelö, 34 (21)

Vickery, G. (1996): Globalisation in the automobile industry, in: OECD: Globalisation of Industry, (pp. 153-205), Paris: OECD

Womack, J. P., Jones, D. T. and Roos, D. (1991): The Machine that Change the World (paperback edition), New York: Harper Perennial 


\section{Statistical annex for international comparisons}

Table 4. 14: Economic weight of Manufacture of motor vehicles, trailers and semitrailers (NACE 34), EU25 vs. Hungary, 2000-20002 (\%)

\begin{tabular}{|l|c|c|c|c|c|c|}
\hline & \multicolumn{2}{|c|}{$\mathbf{2 0 0 0}$} & \multicolumn{2}{c|}{2001} & \multicolumn{2}{c|}{2002} \\
\cline { 2 - 7 } & EU 25 & HUN & EU 25 & HUN & EU 25 & HUN \\
\hline Share of value added in manufacturing total & 7,4 & 12,8 & 7,9 & 10,8 & 7,7 & 10,1 \\
\hline Share of employment in manufacturing total & 6,3 & 4,4 & 6,4 & 4,2 & 6,4 & 4,2 \\
\hline
\end{tabular}

Source: Eurostat

Table 4. 15: Apparent labour productivity: Manufacture of motor vehicles, trailers and semi-trailers, (NACE 34), EU25 vs. Hungary, 2000-20002

\begin{tabular}{|l|c|c|c|c|c|c|}
\hline \multirow{2}{*}{} & \multicolumn{2}{|c|}{$\mathbf{2 0 0 0}$} & \multicolumn{2}{|c|}{$\mathbf{2 0 0 1}$} & \multicolumn{2}{c|}{$\mathbf{2 0 0 2}$} \\
\cline { 2 - 7 } & EU 25 & HUN & EU 25 & HUN & EU 25 & HUN \\
\hline Gross value added per employee & 52,6 & 36,1 & 56,4 & 31,1 & 54,9 & 34 \\
\hline $\begin{array}{l}\text { Labour cost per employee } \\
\text { (unit labour cost) }\end{array}$ & 40,3 & 7,7 & 41 & 9,7 & 43,7 & 11,7 \\
\hline
\end{tabular}

Source: Eurostat

Table 4.16: Motor vehicle parts and accessories (NACE 34.3)

Labour productivity, personnel costs and gross operating rate: ranking of the top 3 Member States, 2002

\begin{tabular}{rrrrr}
$\begin{array}{r}\text { Apparent labour } \\
\text { productivity } \\
\text { Rank }\end{array}$ & $\begin{array}{r}\text { Average } \\
\text { (EUR thousand) (1) }\end{array}$ & $\begin{array}{r}\text { Wage adjusted } \\
\text { (EUR thousand) (2) }\end{array}$ & $\begin{array}{r}\text { labour productivity } \\
(\%)(2)\end{array}$ & $\begin{array}{r}\text { Gross operating rate } \\
\text { (\%) (1) }\end{array}$ \\
\hline $\mathbf{1}$ & Austria (72.7) & Germany (49.3) & Czech Republic (214.3) & Malta (19.1) \\
2 & Germany (58.3) & Austria (40.3) & Slovakia (199.3) & Slovakia (14.2) \\
3 & Belgium (57.7) & Belgium (40.1) & Hungary (190.9) & Czech Republic (13.5) \\
\hline
\end{tabular}

(1) Belgium, 2001; Estonia, Greece, Latvia and Luxembourg, not available.

(2) Belgium, 2001; Estonia, Greece, Cyprus, Latvia and Luxembourg, not available.

Source: Eurostat, Structural Business Statistics (Industry, Construction, Trade and Services),

Annual enterprise statistics 


\section{SECTOR STUDY: \\ MANUFACTURE OF MEDICAL AND SURGICAL EQUIPMENT AND ORTHOPAEDIC APPLIANCES IN HUNGARY}

\subsection{PATterns, NATURE AND SOURCE OF R\&D}

The manufacture of medical and surgical equipment and orthopaedic appliances (NACE 33.1 ) is the most dynamically developing and most $R \& D$ intensive sub-division of the manufacture of medical, precision and optical instruments, watches and clocks (NACE 33) industry in Hungary. Its share in the national GDP has reached to $0.1 \%$ by 2003 , thanks to a healthy growth in its production value, albeit from a low absolute number (from $94 \mathrm{~m}$ euro in 1998 to $194 \mathrm{~m}$ euro in 2003). The private R\&D expenditures in NACE 33.1 amounted to 1.5 $\mathrm{m}$ euro in 2004, up from $0.8 \mathrm{~m}$ euro in 1998. The share of R\&D expenditures of the medical instruments industry in the total BERD amounts to $0.5 \%$, that is, $0.6 \%$ of the private $\mathrm{R} \& \mathrm{D}$ expenditures in the manufacturing industry. The number of researchers has increased by four times since 1998. The total number of researchers reached 214 (head counts) in 2004, that is, around $2.4 \%$ of the total number of researchers in the enterprise sector.

Although the other 4 sub-divisions of the manufacture of medical, precision and optical instruments, watches and clocks (instrument engineering) industry exhibit different dynamics with respect to performance and $\mathrm{R} \& \mathrm{D}$, the analysis below relies on two-digit level data in some cases, when a more detailed division is not available.

The value added generated by the EU25's total instrument engineering industry amounted to $€ 48.7$ bn or 2.8 per cent of the industrial value added in 2001 , and the industry employed 1,002 thousand persons, equivalent to 2.8 per cent of the industrial employment. Labour productivity reached $€ 48,600$ per employee at the average personnel cost of $€ 34,900$ per employee. The manufacture of medical and surgical equipment and orthopaedic appliances sub-division generated 35 per cent $(€ 17.2 \mathrm{bn})$ of the 2-digit industry's value added, which amounted to 1 per cent of the industrial value added. Germany and France were the biggest contributors to this amount with a 39 per cent and a 12 per cent share, respectively. The medical instruments industry employed 40 per cent (401 thousand persons) of the total employment of the instruments industry, which was 1.1 per cent of total industrial employment. By 2003, production of the EU25's medical engineering sector increased to $€ 184 \mathrm{bn}$, which means that European manufacturers produced nearly one third of the world's medical instruments. (Eurostat, 2005)

Similar tendencies can be observed in Hungary, where the medical instruments industry proved to be the most R\&D intensive division of the instruments engineering industry. Generally, the instruments engineering sector performed well with respect to the specified $\mathrm{R} \& \mathrm{D}$ indicators. Although the medical industry produced the highest value indicators in the sector, other sub- divisions, especially the manufacture of office machinery and computers, and the manufacture of radio, television and communication equipment and apparatus also exhibited high R\&D intensities and growth.

R\&D expenditures in the medical instruments industry amounted to $272.8 \mathrm{~m}$ HUF in 2001, 490.8m HUF in 2002, 550.1m HUF in 2003 and 229m HUF in 2004. This means that contributions from the industry generated between 0.5 and 0.9 per cent of the Hungarian 
economy's overall $R \& D$ expenditure. The growth rate of $R \& D$ expenditures in the sector was well above the national average with over 10 per cent in the past five years. The average R\&D intensity of the sector during the 2001-2004 period reached 0.9 per cent in terms of sales revenues and 2.7 per cent in terms of sectoral GDP. The growth rates of these intensities were 2.51 per cent and 34.1 per cent from 2001 to 2003. The sector's output amounted to 0.11 per cent of the national GDP. On the basis of these results, $R \& D$ expenditure in the medical instruments industry was higher and grew faster than the average of the instruments engineering sector. Consequently, it became one of the most R\&D intensive industries of the Hungarian economy.

Longer time series is available only on the evolution of business enterprise financed R\&D in the Hungarian instruments sector (2 digit level).

Table 5.1: BERD in the Hungarian instruments sector, 1995-2003 (m HUF)

\begin{tabular}{|c|c|c|c|c|c|c|c|c|c|}
\hline & $\mathbf{1 9 9 5}$ & $\mathbf{1 9 9 6}$ & $\mathbf{1 9 9 7}$ & $\mathbf{1 9 9 8}$ & $\mathbf{1 9 9 9}$ & $\mathbf{2 0 0 0}$ & $\mathbf{2 0 0 1}$ & $\mathbf{2 0 0 2}$ & $\mathbf{2 0 0 3}$ \\
\hline BERD & $1,068.4$ & $1,021.7$ & 1,979 & 1,929 & $1,328.8$ & $2,596.2$ & $2,234.7$ & $2,425.2$ & $2,333.7$ \\
\hline
\end{tabular}

Source: author's calculations from CSO data

The above figures show that businesses generated nearly 2.2 times as much R\&D expenditure in 2003 than in 1995. This indicates a steady increase during the 9-year period, even though expenditures decreased slightly in some of the observed years. The share of R\&D expenditure of the instruments engineering sector in the total Hungarian R\&D expenditure amounted to 3.9 per cent in 2001, 4 per cent in 2002 and 3.6 per cent in 2003.

For a more detailed analysis of the industry's production performance, labour productivity and R\&D performance, data in most cases are available only at the two-digit (instruments engineering) level. Table 5.2 compares the performance of instruments engineering industry in Hungary and the EU25 total.

Table 5.2: Manufacture of medical, precision and optical instruments, watches and clocks in 2002

\begin{tabular}{|l|c|c|}
\hline & EU25 & Hungary \\
\hline Turnover (m euro) & 12,3686 & 662 \\
\hline Production (m euro) & 11,6670 & 541 \\
\hline Value added (m euro) & 48,735 & 225 \\
\hline Gross operating surplus (m euro) & 16,217 & 86 \\
\hline Number of persons employed (1000) & 1,002 & 22 \\
\hline Personnel costs (m euro) & 32,518 & 140 \\
\hline Labour productivity (1000 euro/head) & 48.6 & 10.5 \\
\hline Average personnel costs (1000 euro/head) & 34.9 & 7.9 \\
\hline Gross operating rate & 13.1 & 13.0 \\
\hline
\end{tabular}

Source: Eurostat

The contribution of the Hungarian instruments engineering is rather marginal to the EU25's production. It produced 0.46 per cent of the production value and the value added, and employed 2.2 per cent of employees of the EU25's instruments engineering sector. Since the share of the Hungarian industry was higher in employment than in production, it proved less 
productive than the EU25 industry. EU25 labour productivity (measured as value added per head) was 4.5 times higher than that of Hungary, although labour costs were also higher by nearly the same proportion.

Data on the evolution of the Hungarian instruments industry's production and sales volumes are also available.

Table 5.3: Evolution of the Hungarian instruments industry, 2003-2005

\begin{tabular}{|l|c|c|c|}
\hline $\begin{array}{l}\text { Percentage change* } \\
\text { in the volume of }\end{array}$ & $\mathbf{2 0 0 3}$ & $\mathbf{2 0 0 4}$ & $\mathbf{2 0 0 5}$ \\
\hline Gross output & 120.0 & 114.1 & 94.3 \\
\hline Total sales & 107.5 & 112.1 & 94.2 \\
\hline \multicolumn{1}{|c|}{ Domestic sales } & 104.7 & 110.3 & 87.0 \\
\hline \multicolumn{1}{|l|}{ Export sales } & 110.5 & 114.0 & 101.8 \\
\hline
\end{tabular}

* previous year $=100 \%$

Source: CSO data

The share of the sector's production was also relatively small in comparison to the Hungarian manufacturing industry. In 1998, it produced 1 per cent of total manufacturing production, 2 per cent of total manufacturing value added and claimed 2 per cent of total manufacturing employment. Since that time, the industry started to grow dynamically. Until 2005, the volume of production increased by 15 per cent and sales increased by 10 per cent per annum on average. Table 5.3 shows that exports grew faster in every year than domestic sales, and thus the bigger part of the increase in sales can be attributed to the expansion of exports.

Table 5.4 presents the main production performance indicators of the Hungarian medical instruments industry and the instruments engineering sector in 1998. The manufacture of medical instruments generated 31 per cent of the output, 30 per cent of the value added and was responsible for 32 per cent of employment in the 2-digit sector. These indicators do not only highlight the importance of the medical instruments industry within instruments engineering, but also show that the structure of the industry is similar to that of the EU25. (At the EU25 level, the sub-division produced 35 per cent of the output and value added (in 2001) with 40 per cent of the workforce of the 2-digit sector.) The industry performed worse in terms of costs and productivity than the average of the 2-digit industry. However, while unit labour costs were 12 per cent lower in the medical instruments industry, labour productivity was only 6 per cent lower than in the instruments engineering sector. 
Table 5.4: Overview of the Hungarian medical instruments and instruments engineering industries, 1998

\begin{tabular}{|l|c|c|}
\hline & $\begin{array}{c}\text { Manufacture of } \\
\text { medical instruments }\end{array}$ & $\begin{array}{c}\text { Instruments } \\
\text { engineering }\end{array}$ \\
\hline $\begin{array}{l}\text { Number of persons employed } \\
(1000)\end{array}$ & 4.8 & 15.0 \\
\hline Production value (m euro) & 94.1 & 301.5 \\
\hline Value added (m euro) & 36.6 & 122.4 \\
\hline Gross operating surplus (m euro) & 13.8 & 42.6 \\
\hline Personnel costs (m euro) & 22.5 & 79.8 \\
\hline $\begin{array}{l}\text { Labour productivity } \\
(1000 \text { euro/head) }\end{array}$ & 7.6 & 8.1 \\
\hline $\begin{array}{l}\text { Unit personnel costs } \\
(1000 \text { euro/head) }\end{array}$ & 4.8 & 5.4 \\
\hline $\begin{array}{l}\text { Social security costs/ total } \\
\text { personnel costs }(\%)\end{array}$ & 27.1 & 27.2 \\
\hline
\end{tabular}

Source: Eurostat

Tables 5.5-5.6 present detailed, not readily available information on the evolution of the medical instruments industry between 1997 and 2002. ${ }^{29}$ It must be noted that the medical instruments industry consist of a large number of companies, that differ substantially with respect to their size, production profile and strategy.

While employment in the industry increased by 30 per cent from 1997 to 2002, value added increase by 75 per cent and net sales revenues have doubled during this period. Pre-tax profits amounted to ten times as much in 2002, than their 1997 value (all data in current price). Exports played a determinant role in the increase of net sales revenues, as export sales have also nearly doubled. Since earnings grew faster than employment, labour productivity also increased. Sales per employee increased from 4.4m HUF in 1997 to $6.6 \mathrm{~m}$ HUF in 2002, and the growth of value added per employee was even more spectacular from $1.8 \mathrm{~m}$ HUF to $2.5 \mathrm{~m}$ HUF. The fairly stable profits/sales and value added/sales ratios from 2000 indicate that revenues and profits grew at a similar pace in the end of the period. The $R \& D$ expenditure per employee indicator shows that R\&D was funded at a rather stable and low level, even in the end of the period. (Sub-division level R\&D data is available only from 2001.) Between 2000 and 2002, 1 - 1,5 per cent of the sales revenues were spent on R\&D in the medical instruments industry.

\footnotetext{
${ }^{29}$ Calculations are based on data from companies on double entry book keeping and employing more than 10 people.
} 
Table 5.5: Overview of the Hungarian medical instruments industry, 1997-2002

\begin{tabular}{|l|c|c|c|c|c|c|}
\hline & $\mathbf{1 9 9 7}$ & $\mathbf{1 9 9 8}$ & $\mathbf{1 9 9 9}$ & $\mathbf{2 0 0 0}$ & $\mathbf{2 0 0 1}$ & $\mathbf{2 0 0 2}$ \\
\hline $\begin{array}{l}\text { Number of } \\
\text { employees }\end{array}$ & 4016 & 4452 & 3965 & 4050 & 4158 & 5241 \\
\hline $\begin{array}{l}\text { Net sales revenue } \\
\text { (bn HUF) }\end{array}$ & 17.8 & 23.8 & 22.3 & 26.7 & 27.2 & 34.8 \\
\hline $\begin{array}{l}\text { Net export revenue } \\
\text { (bn HUF) }\end{array}$ & 7.8 & 12.1 & 10.9 & 12.8 & 13.9 & 15.5 \\
\hline $\begin{array}{l}\text { Pre-tax profits } \\
\text { (bn HUF) }\end{array}$ & 2.1 & 2.0 & 14.7 & n.a. & 19.4 & 22.4 \\
\hline $\begin{array}{l}\text { Value added } \\
\text { (bn HUF) }\end{array}$ & 7.5 & 8.4 & 7.5 & 9.0 & 10.3 & 13.1 \\
\hline $\begin{array}{l}\text { Equity } \\
\text { (bn HUF) }\end{array}$ & 6.4 & 6.2 & 7.2 & 6.2 & 6.3 & 7.0 \\
\hline $\begin{array}{l}\text { Loans* } \\
\text { (bn HUF) }\end{array}$ & 0.0 & 0.0 & 1.9 & 0.2 & 0.1 & 0.5 \\
\hline $\begin{array}{l}\text { Foreign ownership } \\
\text { (\% of equity) }\end{array}$ & 16.8 & 11.0 & 15.8 & 19.7 & 23.7 & 26.6 \\
\hline $\begin{array}{l}\text { State ownership } \\
\text { (\% of equity) }\end{array}$ & 7.5 & 18.1 & 14.6 & 7.0 & 5.5 & 4.9 \\
\hline
\end{tabular}

* loans specifically for investment and development purposes

Source: author's calculation from CSO data

Table 5.6: R\&D intensity and efficiency of the Hungarian medical instruments industry, 2000-2002

\begin{tabular}{|c|c|c|c|c|c|}
\hline & $\begin{array}{c}\text { R\&D } \\
\text { expenditure/ } \\
\text { employee* }\end{array}$ & $\begin{array}{c}\text { Sales/ } \\
\text { employe** }\end{array}$ & $\begin{array}{c}\text { Value added/ } \\
\text { employee* }\end{array}$ & Profits / sales & $\begin{array}{c}\text { Value added / } \\
\text { sales }\end{array}$ \\
\hline $\mathbf{2 0 0 0}$ & 0.07 & 6.6 & 2.2 & - & 0.33 \\
\hline $\mathbf{2 0 0 1}$ & 0.11 & 6.5 & 2.5 & 0.71 & 0.38 \\
\hline $\mathbf{2 0 0 2}$ & 0.1 & 6.6 & 2.5 & 0.64 & 0.33 \\
\hline
\end{tabular}

*m HUF/head

Source: author's calculation from CSO data

It is interesting to note, that despite its profitability, the medical instruments industry did not attract as much foreign investment as other high growth potential industries in the Hungarian economy. The share of foreign ownership remained around one-fourth of the industry, which is quite low compared to the rest of R\&D-intensive industries. The share of state ownership is nearly negligible in the industry. Another interesting feature is that companies in the industry practically did not use loans to finance their investments and development projects.

\subsection{DETERMINANTS OF R\&D}

EU25 level statistics suggest that the evolution of the instruments engineering sector was fairly stable between 1993 and 2004, with an annual average growth rate of production of 3.3 per cent. At the same time, production of the whole of electrical machinery and optical 
equipment sector grew by 5.5 per cent on average, while the growth rate of total industrial production reached only 2.8 per cent.

Generally, instruments engineering is classified as a high-tech industry and companies in the industry rely heavily on continuous product innovation. There are three main reasons for this. First, the demand for durable goods is strongly correlated with the overall condition of the economy, and manufacturers face a volatile demand if market conditions deteriorate. In this case, demand can be boosted by the development of new, superior products. The second reason is that competition from Far Eastern manufacturers has increased dramatically during the past decade and this has created a continuous pressure for EU manufacturers for product development. Third, new technological standards and regulations have been introduced, which are especially relevant in the case of the medical instruments industry.

One of the most important events in this respect was the adoption of Directive 2004/22/EC by the Council and the European Parliament in March 2004 on the manufacturing of measuring instruments. The aim of the directive is to harmonise the production of ten categories of measuring instruments within the EU, and introduce a regulatory framework, which complies with the relevant international standards. The new regulation facilitates that manufacturers can apply different conformity assessment procedures and promotes technological innovation.

A large number of companies constitute the Hungarian medical instruments industry, which differ substantially with respect to their size, financial and R\&D capacities, as well as strategies. The most prominent medical manufacturers are represented by the Association of Hungarian Medical Manufacturers and Service Providers, founded in 1994. The association consists of 50 members, from four main fields of the industry: production of medical instruments, surgical equipment, laboratory equipment and materials, and therapeutic and rehabilitation materials and services. All the member companies are manufacturers or service providers in the above fields, in Hungarian majority ownership and hold a significant market share. The two main activities of the association are to serve as the representative body of interests of the members, and support their activities on the international market.

MEDICOR is the oldest and largest representative of the Hungarian medical instruments industry. The company was established more than four decades ago and its main activities include R\&D, manufacturing and distribution of medical equipment. The company focuses on the mid-price segment of the primary health care market in Hungary and on its 30 export markets. The company's contracts and projects generate $€ 56.3 \mathrm{~m}$ per year, of which amount 90 per cent is performed on the export markets. The main individual activity of MEDICOR is the manufacturing and distribution of different diagnostic X-ray configurations. MEDICOR has developed a network of partner companies, each specialising in the production of equipment for specific fields only. The company also distributes the products of the partner companies, including paediatric (Neonatal) devices, disposable products, functional diagnostic equipment, surgical instruments and operating theatre equipment.

MEDICOR Elektronika Rt, with sales revenues between 400 - 600m HUF, and share equity of $100 \mathrm{~m}$ HUF is a decisive member of the MEDICOR Group. The company is in a 100 per cent Hungarian private ownership. The company is engaged in independent technical development and production of a wide-ranged of medical equipment for both domestic and foreign markets. The main product groups include hospital equipment and home appliances as well. Within the group of hospital products, the company focuses on the production of 
infant medical, and infusion equipment and its main products include neonatal incubators, neonatal warm up and resuscitation tables, blue-light lamps, apnoea alarm devices, infusion pumps, ECG Holter and EEG devices, gels and electrodes. The main products of the home equipment business are blood pressure meters, physiotherapy stimulators, body thermometers and infant respiration monitors.

Innomed Medical Rt is one of the biggest and the most innovative medical instruments manufacturing companies in Hungary. The company employs 220 persons in Hungary, and exports to 106 countries all over the world. The main activity of the company includes the development, distribution and service of medical equipment. The company focuses on the development of the following product groups: heart screening and Holter systems, defibrillators, monitoring systems and x-ray equipment. During its 27 years of operation, the company has demonstrated its commitment for the production of innovative medical equipment on many occasions. This resulted in an international recognition for the company's products as well as in a number of prizes and awards in Hungary. These include the XIV. Innovation Grand Prize by the Hungarian Patent Office in 2005, for the INNOSPOT $1000 \mathrm{~T} / \mathrm{TM}$ pulmonary $\mathrm{x}$-ray station. The development of the same product was also granted 69m HUF support from the GVOP Programme (National Development plan). The professional performance of the company was also acknowledged by an award by the Ministry of Economy and Transport in 2005. 


\section{Box 5.1}

\section{R\&D at a medical equipment manufacturer}

The scope of research activity includes the development of new products and the adaptation of licensed products to the home market. In both cases, the results are utilised in the form of new products and processes. The main research objectives are to develop medical equipment and devices in the field of radiology and cardiology. The share of software-development has also increased during the past few years. The company feels that knowing the needs of their customers is a major contributor to the success of their product and process development activities.

The company's R\&D unit employs 35 engineers, mainly mathematicians and physicists. Most of their researchers have multiple degrees (in various fields). On average, 10 researchers produce 2 innovations. This very well-trained personnel can independently manage the entire development process regarding new possibilities in the field of radiology and cardiology. The company cooperates with universities in many $R \& D$ projects. Competition is severe among the companies of the industry to attract well trained personnel, therefore providing sufficient motivation for the staff in the form of wages is a key challenge for the company.

The company's strategy is to reinvest its profits in order to provide sound financial backgrounds for $R \& D$. R\&D is seen as a key contributor to the company's success as a significant share of the company's turnover is generated by its own product innovations. $\mathrm{R} \& \mathrm{D}$ also plays a crucial role in pursuing the basic strategic concepts of the company: cost reduction, enhanced competitiveness and adaptation to new environmental regulations. All three activities are strongly linked to the company's R\&D performance.

The company could significantly benefit from national and EU-financed R\&D grants that support R\&D, but based on the company's experience, these schemes operate as obstructive factors because of their slow, ex-post financing and the long evaluation process. This means that enterprises with less capital resources have no chance for taking advantage of these R\&D grants. The company expects that indirect financial measures, such as the preferential treatment of software-development in 2006 will foster the company's R\&D activities. On the other hand, abolishment of the tax allowance on the costs of medical equipment for family doctors is likely to decrease demand substantially, which, in turn shall hamper R\&D activities.

\subsection{SUMMARY}

Unfortunately further data is not available for the analysis of the effects of R\&D on the performance of the Hungarian medical instruments industry. Studies and sectoral analyses that systematically analyse the relationship between R\&D and company performance are not available. Occasionally press releases and studies that examine the general state of R\&D in Hungary shed some light on certain aspects of the issue. 
On the basis of the above analysis we can conclude that the manufacture of medical equipment is truly an R\&D-intensive industry. The R\&D-intensity of the sector is not only higher than that of the whole electrical and optical instruments sector but it also produces higher growth. These tendencies are in line with the changes that can be observed in the industry at the EU25 level.

The most important trends in the world's medical instruments industry play a determining role in the innovation activities of the Hungarian companies. These trends include the increasing use of IT systems for the support of medical equipment, the revolution of digital imaging equipment and the expansion of the home-use appliances market. Besides research and development of the traditional equipment, Hungarian medical equipment manufacturers proved successful in the development and application of these product families.

\subsection{REFERENCES}

Eurostat [2005]: Panorama of the European Union, European Business Facts and Figures 1995-2004, http://epp.eurostat.cec.eu.int/portal/

Association of the Hungarian Medical Manufacturers and Service Providers, www.mdma.hu Medicor Rt. www.medicor.hu

Innomed Medical Rt, www.innomed.hu 


\section{CONCLUSIONS}

This report has been written as part of an ETEPS project analysing private sector R\&D activities in the new EU member states. As a first contribution, data availability and reliability have been assessed in Hungary. The Hungarian Central Statistical Office (CSO) has been collecting R\&D data since 1969. During this 40 year period, data collection and publication methods had changed several times: the Recommendations Concerning the International Standardisation of Science and Technology by the UNESCO had been followed since 1978, then the Frascati Manual (OECD) from the early 1990s (with practically full compliance since $1996^{30}$ ), and its most recent, EUROSTAT compatible version from 2002.

More recently, innovation surveys are also conducted in Hungary by the CSO. The first, pilot innovation survey, following the harmonised OECD-Eurostat guidelines (Community Innovation Survey, CIS) was conducted in 2000. Then, the Hungarian CIS survey was run in 2002, covering the period of 1999-2001. A CIS Light survey, conducted in 2004, and the Hungarian CIS4 survey results are being processed at the time of writing this report, due to be published in September 2006.

Practically all relevant R\&D data are collected in Hungary, and thus, in principle, those data are available. In terms of using available data, there are two major problems in Hungary. First, only a limited set of data are published, and thus made available free of charge. This limitation has two aspects: level of aggregation (data are published for only a few sectors at a NACE 2-digit level; see Appendices 8-10), and the indicators. In other words, if one needs more indicators (besides $R \& D$ expenditures, personnel or the number of $R \& D$ units), or figures at a NACE 2 digit level in most industries, or data at NACE 3-digit level, the costs of data procession have to be incurred. Obviously, this practice prevents detailed analyses, required both for deepening our theoretical understanding of RTDI processes, as well as for policy purposes.

Second, the way in which data protection is understood and implemented is also posing a challenge from the point of view of theoretical investigations, policy analysis, and ultimately policy-making. For instance, the list of R\&D performing companies is not available, and thus it is not possible to conduct even the most elementary calculations, e.g. to establish how many of the top exporters conduct R\&D activities in Hungary. It would be a fairly simple and cheap exercise, and given the weight of exporting firms in the small, open Hungarian economy, a rather pertinent one. It is not possible to analyse the impacts of R\&D and innovation on micro-economic performance, either, although these three sets of data $(R \& D$, innovation, and company performance data) are collected - but using different surveys and thus stored in different data sets, which cannot be linked for legal restrictions. In other words, public money is spent on collecting data, which cannot be used for analyses aimed at supporting public policies.

This issue has been raised by experts at numerous occasions - in various papers and reports, e.g. the TrendChart on Innovation country reports, at workshops, etc. - in recent years. The Science, Technology Policy and Competitiveness Advisory Board - an expert body advising the Science and Technology Policy Committee, headed by the prime minister - has commissioned a study on the methods and statistics used in the Hungarian RTDI policy-

\footnotetext{
${ }^{30}$ Minor differences occur in the case of military R\&D expenditure, but this is not of major relevance, given the relatively low amount spent on military $R \& D$ activities.
} 
making system, and this report is likely to recommend easing the above limitations. (The final version of the report is not publicly available as of yet.)

The conclusions of the sectoral case studies are presented in Sections 3-5. Given the importance of sectoral characteristics, only a few overall conclusions can be drawn here. First, business R\&D expenditures are very low in Hungary: 0.33\% of GDP (in 2004), which is less than one third of the EU25 average. Second, BERD is highly concentrated in Hungary: pharmaceuticals industry accounts for more than on third of the total (34.4\% in 2004).Case study evidence suggests that BERD is concentrated in terms of size and ownership, too: the bulk of BERD is spent by large, foreign-owned companies. (These data at a national or sectoral level are not publicly available, either - but can be purchased.)

Our four sectoral case studies confirm the dominant role of foreign-owned firms in RTDI activities, too. Foreign-owned firms tend to be large, and thus the decisive share of BERD is performed by large enterprises. Using Eurostat data, one can calculate the share of large firms (with 250 or more employees) in total R\&D expenditures: 96\% (2003); and in total R\&D personnel in manufacturing industry: 78\% (2004).

As for the major conclusions of the sectoral case studies, pharmaceuticals industry is the most R\&D intensive sector in Hungary, in line with the global trends of this sector. The sectoral research system has been radically restructured during the past fifteen years as foreign pharmaceuticals manufacturers became majority owners in most companies, pursuing global R\&D strategies. In Hungary, they focus on the development of generic drugs. Thus, the number of research projects has decreased, but the allocation of R\&D expenditures became more efficient.

The most important trends in the world's medical instruments industry play a determining role in the innovation activities of the Hungarian companies. These trends include the increasing use of IT systems for the support of medical equipment, the revolution of digital imaging equipment and the expansion of the home-use appliances market. Besides research and development of the traditional equipment, Hungarian medical equipment manufacturers proved successful in the development and application of these product families.

Automotive industry has been traditionally less R\&D intensive, yet, innovation, $R \& D$ and engineering skills are becoming decisive factors of success for automotive firms, too, given the fierce competition, requiring improved products in terms of safety, comfort, and fuel efficiency, assisted - and, in the meantime, pressed - by ever faster technological changes. Given the excellence of the Hungarian higher education system, there is no shortage of engineers endowed with these skills and knowledge. Interviews suggest emerging cooperation between automotive firms, on the one hand, and university departments as well as other R\&D units, on the other. More recently, some foreign investors - e.g. Audi, GM Opel, ITT, Knorr-Bremse and ZF - have also realised the world-class knowledge of Hungarian scientists and engineers, and they are setting up either their in-house R\&D units or joint research groups with universities. Again, besides professional excellence, there is a considerable cost advantage in this field, too. Further, in the second half of the 1990s, R\&D schemes were also applied to foster innovation activities in the automotive industry, and a new one was launched in 2006.

The successful re-structuring of the Hungarian automotive industry is not only due to some 'push' factors, i.e. the fierce competition among automotive companies and hence the pursuit 
of cost-cutting via re-location of their production, but it also thanks to 'pull' factors, i.e. the attractions of the Hungarian economic environment, broadly defined. Given the ever changing, and global, nature of the automotive industry, no country can be complacent, on the contrary, continuously renewed, concerted efforts and well-devised policy measures are needed to achieve further results. 


\section{APPENDICES}

Appendix 1: Availability of sectoral data on private R\&D in Hungary 


\begin{tabular}{|c|c|c|c|c|c|c|c|c|c|c|c|c|c|c|}
\hline \multirow[b]{2}{*}{$\begin{array}{l}\text { Indicator } \\
\text { No }\end{array}$} & \multirow[b]{2}{*}{ List of indicators } & \multirow[b]{2}{*}{$\begin{array}{l}\text { Source } \\
\text { No. (1) }\end{array}$} & \multirow[b]{2}{*}{ Data source (2) } & \multirow[b]{2}{*}{$\begin{array}{l}\text { Publishing } \\
\text { organisation } \\
\text { (2a) }\end{array}$} & \multirow[b]{2}{*}{$\begin{array}{l}\text { Availability } \\
\text { aggef } \\
\text { agated ed } \\
\text { data for } \\
\text { w hole } \\
\text { economy (3) }\end{array}$} & \multicolumn{3}{|c|}{$\begin{array}{l}\text { NACE-code of avaliabble } \\
\text { sectoral data }(4)\end{array}$} & \multicolumn{6}{|c|}{ Available years - NACE code (5) } \\
\hline & & & & & & $\begin{array}{l}\text { NACE } \\
\text { code } \\
\text { letters }\end{array}$ & 2 digit level & $\begin{array}{l}3 \text { digit } \\
\text { level }\end{array}$ & $\begin{array}{l}\text { general } \\
\text { availability } \\
{ }_{*}\end{array}$ & $\begin{array}{c}\text { Manufacture of } \\
\text { pharmaceuticals } \\
\text {; } 244\end{array}$ & 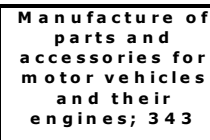 & $\begin{array}{c}\text { Manufacture } \\
\text { in medical } \\
\text { instruments; } \\
331\end{array}$ & $\mid \begin{array}{c}\text { Manufacture of } \\
\text { othe re e e e cetric } \\
\text { equipm ant } \\
316 \\
316\end{array}$ & $\mid \begin{array}{l}\text { excepti } \\
\text { for spec } \\
\text { secto }\end{array}$ \\
\hline \multirow{4}{*}{1} & \multirow{4}{*}{ 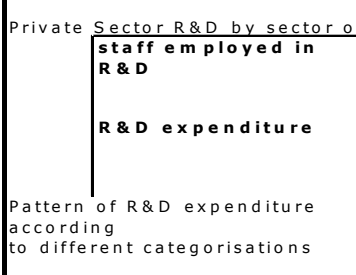 } & & $\begin{array}{l}\text { i c cactivity } \\
\text { IKutatás és fejlesztés/Research }\end{array}$ & CSO & & & & & & & & & & \\
\hline & & & $\begin{array}{l}\text { and oevelopiment (bilingual } \\
\text { annual publication) }\end{array}$ & & r & 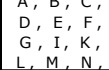 & $\begin{aligned} 15 ; 24 ; 29 ; \\
31 ; 33 ; 73\end{aligned}$ & (s) & $1993-2004$ & (s) & (s) & (s) & (s) & \\
\hline & & & 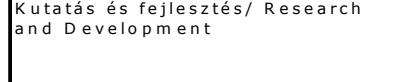 & cso & r & 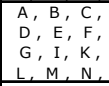 & $\begin{array}{l}15 ; 24 ; 29 ; \\
31 ; 33 ; 73\end{array}$ & (s) & $1993-2004$ & (s) & (s) & (s) & (s) & \\
\hline & & & & & & & & & & & & & & \\
\hline \multirow{2}{*}{$\begin{array}{l}3 \\
4\end{array}$} & $\begin{array}{c}\text { in-house-outsourced } \\
\text { |in-house R \& D } \\
\text { expenditure }\end{array}$ & & unpublished & & Y & (s) & (s) & (s) & $1993-2004$ & (s) & (s) & (s) & (s) & \\
\hline & \begin{tabular}{|l} 
expenditure \\
outsourced $R$ \& D D \\
expenditure
\end{tabular} & & unpublished & & $\mathrm{Y}$ & (s) & (s) & $(s)$ & $1993-2004$ & (s) & ( & (s) & (s) & \\
\hline \multirow{3}{*}{5} & 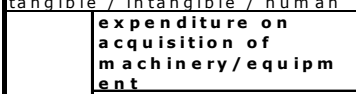 & & $\begin{array}{l}\text { Kutatás és fejilesztés/ Research } \\
\text { and Development }\end{array}$ & & r & (s) & (s) & (s) & $1993-2004$ & & & & & \\
\hline & $\begin{array}{l}\text { expenditure on } \\
\text { actuisition of know. } \\
\text { how }\end{array}$ & & n.a. & & n & (s) & (s) & (s) & $1993-2004$ & & & & & \\
\hline & $\begin{array}{l}\text { investment in } \\
\text { human resources }\end{array}$ & & $\begin{array}{l}\text { Kutatás és fejlesztés/ Research } \\
\text { and Development }\end{array}$ & cso & r & (s) & (s) & (s) & $1993-2004$ & (s) & (s) & (s) & (s) & \\
\hline \multirow[t]{3}{*}{8} & 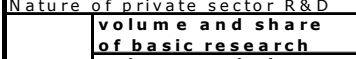 & & $\begin{array}{l}\text { Kutatás és fejlesztés/Research } \\
\text { and Development }\end{array}$ & cso & r & $(\mathrm{s})$ & (s) & $(\mathrm{s})$ & $1993-2004$ & (s) & (s) & (s) & (s) & \\
\hline & $\begin{array}{l}\text { oolume and share } \\
\text { of applied research }\end{array}$ & & $\begin{array}{l}\text { Kutatás és fijlesstés/Research } \\
\text { and Development }\end{array}$ & cso & r & (s) & (s) & (s) & $1993-2004$ & 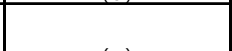 & & & & \\
\hline & $\begin{array}{l}\text { Volumeand share } \\
\text { of experimental } \\
\text { development }\end{array}$ & & $\begin{array}{l}\text { Kutatás és fejleszztés/Research } \\
\text { and Development }\end{array}$ & cso & r & (s) & (s) & (s) & $1993-2004$ & (s) & (s) & (s) & & \\
\hline 10 & $\begin{array}{l}\text { olume and share } \\
\text { of new product } \\
\text { development }\end{array}$ & & $\begin{array}{l}\text { Inn ováció } 1999-20011 \\
\text { In novation } 1999-2001 * *\end{array}$ & cso & r & 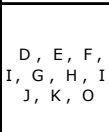 & 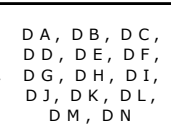 & (s) & $1999-2001$ & & & & & \\
\hline 11 & $\begin{array}{l}\text { Volume and share } \\
\text { of new product } \\
\text { development }\end{array}$ & & In nováció 2003 /Innovation 2003 & $\operatorname{cso}$ & r & $\mathrm{C}, \mathrm{D}, \mathrm{E}$, & 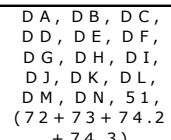 & (s) & 2003 & & & & & \\
\hline 11 & $\begin{array}{l}\text { Volume and share } \\
\text { of product } \\
\text { improvement }\end{array}$ & & $\begin{array}{l}\text { Innovációo } 1999-2001 \\
\text { Innovation 1999-2001 }\end{array}$ & cso & r & I, G, H, & 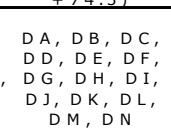 & (s) & $1999-2001$ & & & & & \\
\hline 12 & $\begin{array}{l}\text { Volume and share } \\
\text { oolproduct } \\
\text { improvement }\end{array}$ & & Innováció 2003 / Innovation 2003 & cso & r & $\mathrm{C}, \mathrm{D}, \mathrm{E}, \mathrm{E}$, & 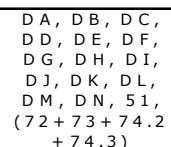 & (s) & 2003 & & & & & \\
\hline
\end{tabular}


Appendix 2: Reliability of sectoral data sources on private R\&D in Hungary

\begin{tabular}{|c|c|}
\hline Source No. & 1 \\
\hline Data Source & $\begin{array}{l}\text { Kutatás és fejlesztés/ Research and Development } \\
\text { (annual bilingual publication) }\end{array}$ \\
\hline Publishing organisation & Central Statistical Office \\
\hline \multicolumn{2}{|l|}{ 1. Technical reliability: } \\
\hline $\begin{array}{l}\text { a. Is the method in accordance with } \\
\text { Commission Regulation No } 753 / 2004 \text { on } \\
\text { statistics on science and technology? }\end{array}$ & Yes \\
\hline b. Standard used for R\&D survey: & Frascati Manual \\
\hline $\begin{array}{l}\text { c. Explicit differences between national R\&D } \\
\text { surveys and Frascati Manual }\end{array}$ & $\begin{array}{l}\text { Minor differences in the case of military R\&D } \\
\text { expenditures. }\end{array}$ \\
\hline $\begin{array}{l}\text { d. "Implicit" differences between the } \\
\text { standard national economic or educational } \\
\text { classifications used in the country's surveys } \\
\text { and the international classification } \\
\text { recommended by the Frascati Manual (2002) }\end{array}$ & No \\
\hline $\begin{array}{l}\text { e. Data source: sample survey, } \\
\text { administrative data sources or other data } \\
\text { sources }\end{array}$ & $\begin{array}{l}\text { Survey including every company that is identified } \\
\text { as an R\&D performer. }\end{array}$ \\
\hline $\begin{array}{l}\text { f. Method of data collection: Census/sample } \\
\text { survey, estimation, combination of both }\end{array}$ & Census, annually from 1969 \\
\hline $\begin{array}{l}\text { g. Inclusion of SMEs smaller than } 10 \\
\text { employees? }\end{array}$ & Yes \\
\hline $\begin{array}{l}\text { h. Inclusion of all enterprises performing } \\
\text { R\&D, either continuously or occasionally in } \\
\text { the R\&D survey? }\end{array}$ & Yes \\
\hline \multicolumn{2}{|l|}{ 2. Theoretical pitfalls: } \\
\hline $\begin{array}{l}\text { a. Caveats for breaks in time series (e.g. } \\
\text { change in tax incentives, change in data } \\
\text { collection method, definition of R\&D } \\
\text { employees etc.) }\end{array}$ & $\begin{array}{l}\text { The CSO has been collecting R\&D data since } \\
1969 \text {. During this } 40 \text { year period, the data } \\
\text { collection and publication methods changed } \\
\text { according to the specifications of the relevant } \\
\text { guidelines, i. e the Recommendations Concerning } \\
\text { the International Standardisation of Science and } \\
\text { Technology by the UNESCO from } 1978 \text {, the } \\
\text { Frascati Manual by the OECD from 1996, and its } \\
\text { most recent EUROSTAT compatible version from } \\
2002 \text {. }\end{array}$ \\
\hline $\begin{array}{l}\text { b. Caveats for international comparison (e.g. } \\
\text { national peculiarities of innovation systems } \\
\text { and framework conditions) }\end{array}$ & No \\
\hline c. Others & No \\
\hline
\end{tabular}




\begin{tabular}{|c|c|}
\hline $\begin{array}{l}\text { Source } \\
\text { No. }\end{array}$ & 2 \\
\hline Data Source (2) & Innováció 1999-2001 / Innovation 1999-2001 \\
\hline Publishing organisation (2a) & Central Statistical Office \\
\hline \multicolumn{2}{|l|}{ 1. Technical reliability: } \\
\hline $\begin{array}{l}\text { a. Is the method in accordance with Commission } \\
\text { Regulation No 753/2004 on statistics on science and } \\
\text { technology? Yes / No }\end{array}$ & Yes \\
\hline $\begin{array}{l}\text { b. Standard used for R\&D survey: Frascati } \\
\text { Manual, Canberra Manual or other harmonised } \\
\text { standards }\end{array}$ & $\begin{array}{l}\text { The data are CIS3 compatible, based on the Oslo Manual for } \\
\text { the Measurement of Scientific and Technological Activities. }\end{array}$ \\
\hline $\begin{array}{l}\text { c. Explicit differences between national R\&D } \\
\text { surveys and Frascati Manual }\end{array}$ & No \\
\hline $\begin{array}{l}\text { d. "Implicit" differences between the standard } \\
\text { national economic or educational classifications used } \\
\text { in the country's surveys and the international } \\
\text { classification recommended by the Frascati Manual } \\
\text { (2002). }\end{array}$ & No \\
\hline $\begin{array}{l}\text { e. Data source: sample survey, administrative } \\
\text { data sources or other data sources }\end{array}$ & Representative sample survey posted to the companies \\
\hline $\begin{array}{l}\text { f. Method of data collection: Census/sample } \\
\text { survey, estimation, combination of both (for which } \\
\text { year) }\end{array}$ & Survey conducted in 2002 for the $1999-2001$ period \\
\hline $\begin{array}{l}\text { g. Inclusion of SMEs smaller than } 10 \text { employees? } \\
\text { Yes/No }\end{array}$ & No \\
\hline $\begin{array}{l}\text { h. Inclusion of all enterprises performing } R \& D \text {, } \\
\text { either continuously or occasionally in the R\&D } \\
\text { survey? Yes/No }\end{array}$ & No \\
\hline \multicolumn{2}{|l|}{ 2. Theoretical pitfalls: } \\
\hline $\begin{array}{l}\text { a. Caveats for breaks in time series (e.g. change } \\
\text { in tax incentives, change in data collection method, } \\
\text { definition of R\&D employees etc.) }\end{array}$ & $\begin{array}{l}\text { This specific publication is based on a } 2002 \text { survey, which was } \\
\text { CIS3 compatible, run on } 6,100 \text { companies, covering all } \\
\text { sectors of the economy, except for mining and quarrying. } \\
\text { Besides this activity, there was a pilot innovation survey } \\
\text { conducted in } 2000 \text {. That pilot exercise included } 1,700 \\
\text { companies from the manufacturing industry. }\end{array}$ \\
\hline $\begin{array}{l}\text { b. Caveats for international comparison (e.g. } \\
\text { national peculiarities of innovation systems and } \\
\text { framework conditions) }\end{array}$ & ( \\
\hline c. Others & No \\
\hline
\end{tabular}




\begin{tabular}{|c|c|}
\hline $\begin{array}{l}\text { Source } \\
\text { No. }\end{array}$ & 3 \\
\hline Data Source (2) & Innováció 2003 / Innovation 2003 \\
\hline Publishing organisation $(2 \mathrm{a})$ & Central Statistical Office \\
\hline \multicolumn{2}{|l|}{ 1. Technical reliability: } \\
\hline $\begin{array}{l}\text { a. Is the method in accordance with Commission } \\
\text { Regulation No } 753 / 2004 \text { on statistics on science and } \\
\text { technology? Yes / No }\end{array}$ & Yes \\
\hline $\begin{array}{l}\text { b. Standard used for R\&D survey: Frascati } \\
\text { Manual, Canberra Manual or other harmonised } \\
\text { standards }\end{array}$ & $\begin{array}{l}\text { The data are CISLight compatible, based on the Oslo Manual } \\
\text { for the Measurement of Scientific and Technological Activities. }\end{array}$ \\
\hline $\begin{array}{l}\text { C. Explicit differences between national R\&D } \\
\text { surveys and Frascati Manual }\end{array}$ & No \\
\hline $\begin{array}{l}\text { d. "Implicit" differences between the standard } \\
\text { national economic or educational classifications used } \\
\text { in the country's surveys and the international } \\
\text { classification recommended by the Frascati Manual } \\
\text { (2002). }\end{array}$ & No \\
\hline $\begin{array}{l}\text { e. Data source: sample survey, administrative } \\
\text { data sources or other data sources }\end{array}$ & Representative sample survey posted to the companies \\
\hline $\begin{array}{l}\text { f. Method of data collection: Census/sample } \\
\text { survey, estimation, combination of both (for which } \\
\text { year) }\end{array}$ & Survey conducted in 2004 (to collect 2003 data) \\
\hline $\begin{array}{l}\text { g. Inclusion of SMEs smaller than } 10 \text { employees? } \\
\text { Yes/No }\end{array}$ & No \\
\hline $\begin{array}{l}\text { h. Inclusion of all enterprises performing R\&D, } \\
\text { either continuously or occasionally in the R\&D } \\
\text { survey? Yes/No }\end{array}$ & No \\
\hline \multicolumn{2}{|l|}{ 2. Theoretical pitfalls: } \\
\hline $\begin{array}{l}\text { a. Caveats for breaks in time series (e.g. change } \\
\text { in tax incentives, change in data collection method, } \\
\text { definition of R\&D employees etc.) }\end{array}$ & $\begin{array}{l}\text { This specific publication is based on a CIS Light survey, } \\
\text { conducted in } 2004 \text {, covering all sectors - except for the } \\
\text { construction industries and retail trade, hotels and } \\
\text { restaurants, and other community, social and personal service } \\
\text { activities -, involving 5,094 companies employing more than } \\
10 \text { employees. }\end{array}$ \\
\hline $\begin{array}{l}\text { b. Caveats for international comparison (e.g. } \\
\text { national peculiarities of innovation systems and } \\
\text { framework conditions) }\end{array}$ & No \\
\hline c. Others & No \\
\hline
\end{tabular}




\section{Appendix 3}

1. A luutató-fejlesztö helyelk száma és létszámadatai Number of $R \& D$ units and $R \& D$ personnel data

\begin{tabular}{|c|c|c|c|c|c|c|c|}
\hline \multirow{3}{*}{$\begin{array}{l}\text { Ev } \\
\text { Yoar }\end{array}$} & \multirow{3}{*}{$\begin{array}{l}\text { Kutató- } \\
\text { belyel } \\
\text { száma } \\
\\
\text { Number } \\
\text { of R\&D } \\
\text { wits }\end{array}$} & \multicolumn{6}{|c|}{ Kutató-feilesztỏ helvek - R\&D units } \\
\hline & & \multirow[b]{2}{*}{$\begin{array}{c}\mathrm{K}+\mathrm{F} \\
\text { tényleges } \\
\text { létszám } \\
\text { összesen } \\
\text { (fó) } \\
\text { total } R \square D \\
\text { staff } \\
\text { numbor } \\
\text { (porson) }\end{array}$} & \multicolumn{2}{|c|}{ ebbôl -of which: } & \multirow[b]{2}{*}{$\begin{array}{c}\mathrm{K}+\mathrm{F} \\
\text { számitott } \\
\text { létszám } \\
\text { ósszesen") } \\
\text { (fó) } \\
\text { caiculated } \\
\text { staff } \\
\text { number al } \\
\text { (FTE) }\end{array}$} & \multicolumn{2}{|c|}{ ebbôl - of which: } \\
\hline & & & $\begin{array}{l}\text { scientists and } \\
\text { engineers }\end{array}$ & $\begin{array}{c}\text { segéd- } \\
\text { személyzet }\end{array}$ & & $\begin{array}{l}\text { scientists and } \\
\text { engineers }\end{array}$ & $\begin{array}{c}\text { segéd- } \\
\text { személyzet }\end{array}$ \\
\hline 1990 & 1256 & 59723 & 30256 & 17849 & 36384 & 17550 & 11711 \\
\hline 1991 & 1257 & 51218 & 26763 & 14238 & 29397 & 14471 & 8903 \\
\hline 1992 & 1287 & 43879 & 24110 & 11449 & 24192 & 12311 & 7152 \\
\hline $1993^{\text {b) }}$ & 1380 & 40999 & 23012 & 9761 & 22609 & 11818 & 6003 \\
\hline 1994 & 1401 & 39810 & 22401 & 9691 & 22008 & 11752 & 5922 \\
\hline 1995 & 1442 & 38088 & 20859 & 9612 & 19585 & 10499 & 5207 \\
\hline 1996 & 1461 & 37286 & 20485 & 9244 & 19776 & 10408 & 5114 \\
\hline 1997 & 1679 & 39626 & 21999 & 9375 & 20758 & 11154 & 5205 \\
\hline 1998 & 1725 & 41317 & 23547 & 9209 & 20315 & 11731 & 4907 \\
\hline 1999 & 1887 & 42088 & 24609 & 9036 & 21329 & 12579 & 5037 \\
\hline $2000^{b)}$ & 2020 & 45325 & 27876 & 8313 & 23534 & 14406 & 5166 \\
\hline 2001 & 2337 & 45676 & 28351 & 8098 & 22942 & 14666 & 4752 \\
\hline 2002 & 2426 & 48727 & 29764 & 8965 & 23703 & 14965 & 4936 \\
\hline 2003 & 2470 & 48681 & 30292 & 8659 & 23311 & 15180 & 4641 \\
\hline 2004 & 2541 & 49615 & 30420 & 8873 & 22826 & 14904 & 4713 \\
\hline
\end{tabular}

Az elôzõ évi százalékában As percentage of the provious year

$\begin{array}{rrrrrrrr}1995 & 102,9 & 95,7 & 93,1 & 99,2 & 89,0 & 89,3 & 87,9 \\ 1996 & 101,3 & 97,9 & 98,2 & 96,2 & 101,0 & 99,1 & 98,2 \\ 1997 & 114,9 & 106,3 & 107,4 & 101,4 & 105,0 & 107,2 & 101,8 \\ 1998 & 102,7 & 104,3 & 107,0 & 98,2 & 97,9 & 105,2 & 94,3 \\ 1999 & 109,4 & 101,9 & 104,5 & 98,1 & 105,0 & 107,2 & 102,6 \\ 2000 & 107,0 & 107,7 & 113,3 & 92,0 & 110,3 & 114,5 & 102,6 \\ 2001 & 115,7 & 100,8 & 101,7 & 97,4 & 97,5 & 101,8 & 92,0 \\ 2002 & 103,8 & 106,7 & 105,0 & 110,7 & 103,3 & 102,0 & 103,9 \\ 2003 & 101,8 & 99,9 & 101,8 & 96,6 & 98,3 & 101,4 & 94,0 \\ 2004 & 102,9 & 101,9 & 100,4 & 102,5 & 97,9 & 98,2 & 101,6\end{array}$

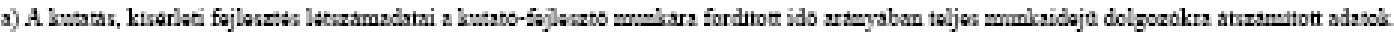
a) Data of employes in RED wits are fill-time equinalent (FTE).

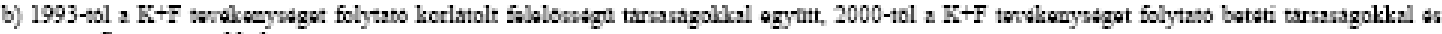
neuprofit szarveze:akkel ogyatt

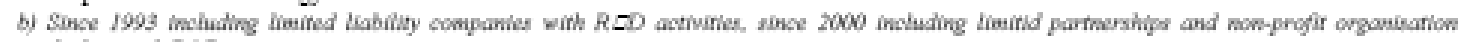
dealing with RaD activines

Source: Hungarian Central Statistical Office, Research and Development 2004 
Appendix 4

\section{A lcutatás-fejlesztés ráfordításadatai $R \& D$ expendïure}

(million $\mathrm{Ft}$ - miliion HUF)

\begin{tabular}{|c|c|c|c|c|c|c|c|}
\hline \multirow{2}{*}{$\begin{array}{l}\text { Ev } \\
\text { Year }\end{array}$} & \multirow{2}{*}{ 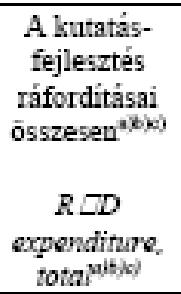 } & \multicolumn{2}{|c|}{ Ebbōl-Of which: } & \multicolumn{4}{|c|}{$\begin{array}{l}\text { A } \mathrm{K}+\mathrm{F} \text { ráforditások pénzuigyi forrásai } \\
R \& D \text { expenditure by financial sources }\end{array}$} \\
\hline & & $\begin{array}{c}\mathrm{K}+\mathrm{F} \\
\text { kōltség } \\
\text { current } \\
\text { expendi- } \\
\text { ture }\end{array}$ & $\begin{array}{c}\text { bern- } \\
\text { házás } \\
\text { capital } \\
\text { expenditure }\end{array}$ & $\begin{array}{c}\text { vállalko- } \\
\text { zások } \\
\text { business } \\
\text { enterprises }\end{array}$ & $\begin{array}{c}\text { állami } \\
\text { költségvetés } \\
\text { govemment }\end{array}$ & $\begin{array}{c}\text { egyéb bazai } \\
\text { források } \\
\text { other } \\
\text { domestic } \\
\text { source }\end{array}$ & $\begin{array}{c}\text { külföldi } \\
\text { források } \\
\text { from abroad }\end{array}$ \\
\hline $\begin{array}{l}1990 \\
1991\end{array}$ & $\begin{array}{l}33725 \\
27103\end{array}$ & $\begin{array}{l}2116 \\
2119\end{array}$ & $\begin{array}{l}3317 \\
2209\end{array}$ & $\begin{array}{l}13075 \\
10974\end{array}$ & $\begin{array}{l}19766 \\
15075\end{array}$ & $\begin{array}{l}538 \\
574\end{array}$ & $\begin{array}{l}346 \\
480\end{array}$ \\
\hline $\begin{array}{l}1992 \\
1993^{\mathrm{d}}\end{array}$ & $\begin{array}{l}31632 \\
35252\end{array}$ & $\begin{array}{ll}23 & 04 \\
25 & 01\end{array}$ & $\begin{array}{l}3359 \\
3593\end{array}$ & $\begin{array}{r}9907 \\
10086\end{array}$ & $\begin{array}{l}19893 \\
22926\end{array}$ & $\begin{array}{r}921 \\
1384\end{array}$ & $\begin{array}{l}911 \\
857\end{array}$ \\
\hline $\begin{array}{l}1994 \\
1995\end{array}$ & $\begin{array}{l}40288 \\
42310\end{array}$ & $\begin{array}{lll}31 & 31 \\
35 & 03\end{array}$ & $\begin{array}{l}4680 \\
4713\end{array}$ & $\begin{array}{l}11565 \\
15292\end{array}$ & $\begin{array}{l}25403 \\
23278\end{array}$ & $\begin{array}{l}1886 \\
1744\end{array}$ & $\begin{array}{l}1434 \\
1997\end{array}$ \\
\hline $\begin{array}{l}1996 \\
1997\end{array}$ & $\begin{array}{l}46027 \\
63591\end{array}$ & $\begin{array}{l}3904 \\
4904\end{array}$ & $\begin{array}{l}5332 \\
8141\end{array}$ & $\begin{array}{ll}17 & 221 \\
23 & 153\end{array}$ & $\begin{array}{l}23558 \\
34854\end{array}$ & $\begin{array}{l}3173 \\
2929\end{array}$ & $\begin{array}{l}2076 \\
2655\end{array}$ \\
\hline $\begin{array}{l}1998 \\
1999\end{array}$ & $\begin{array}{l}71186 \\
78188\end{array}$ & $\begin{array}{l}5624 \\
6140\end{array}$ & $\begin{array}{l}11380 \\
12711\end{array}$ & $\begin{array}{l}26859 \\
30070\end{array}$ & $\begin{array}{l}38930 \\
41624\end{array}$ & $\begin{array}{ll}2 & 022 \\
2 & 131\end{array}$ & $\begin{array}{l}3375 \\
4363\end{array}$ \\
\hline $\begin{array}{l}2000^{d 7} \\
2001\end{array}$ & $\begin{array}{l}105388 \\
140605\end{array}$ & $\begin{array}{r}8135 \\
10523\end{array}$ & $\begin{array}{l}18152 \\
23727\end{array}$ & $\begin{array}{l}39790 \\
48984\end{array}$ & $\begin{array}{l}52207 \\
75386\end{array}$ & $\begin{array}{l}2189 \\
3317\end{array}$ & $\begin{array}{l}11202 \\
12918\end{array}$ \\
\hline $\begin{array}{l}2002 \\
2003\end{array}$ & $\begin{array}{l}171470 \\
175773\end{array}$ & $\begin{array}{l}13416 \\
13852\end{array}$ & $\begin{array}{l}26125 \\
28106\end{array}$ & $\begin{array}{l}50936 \\
53926\end{array}$ & $\begin{array}{l}100392 \\
102008\end{array}$ & $\begin{array}{r}2369 \\
991\end{array}$ & $\begin{array}{l}17773 \\
18847\end{array}$ \\
\hline 2004 & 181525 & 14770 & 25188 & 67352 & 94049 & 1334 & 18791 \\
\hline
\end{tabular}

Az elôzó évi százalékában

As percentage of the previous year

$\begin{array}{rrrrrrrr}1995 & 105,0 & 111,9 & 100,7 & 132,2 & 91,6 & 92,5 & 139,3 \\ 1996 & 108,8 & 111,5 & 113,1 & 112,6 & 101,2 & 181,9 & 104,0 \\ 1997 & 138,2 & 125,6 & 152,7 & 134,4 & 147,9 & 92,3 & 127,9 \\ 1998 & 111,9 & 114,7 & 139,8 & 116,0 & 111,7 & 69,0 & 127,1 \\ 1999 & 109,8^{\circ)} & 109,3 & 111,7 & 112,0 & 106,9 & 105,4 & 129,3 \\ 2000 & 134,8 & 132,4 & 142,8 & 132,3 & 125,4 & 102,7 & 256,7 \\ 2001 & 133,4 & 129,3 & 130,7 & 123,1 & 144,4 & 151,5 & 115,3 \\ 2002 & 122,0 & 127,5 & 110,1 & 104,0 & 133,2 & 71,4 & 137,6 \\ 2003 & 102,5 & 103,2 & 107,6 & 105,9 & 101,6 & 41,8 & 106,0 \\ 2004 & 103,3 & 106,6 & 89,6 & 124,9 & 92,2 & 134,6 & 99,7\end{array}$

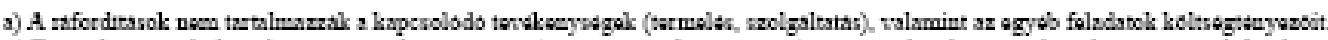

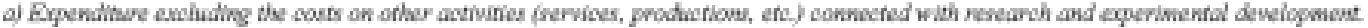

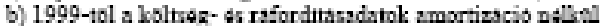

b) Since 1999 casts excinding awortization.

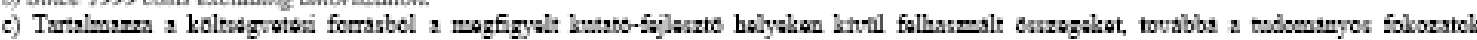

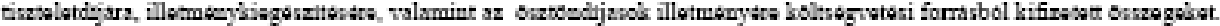

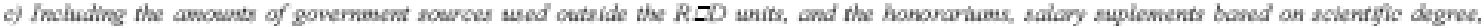
woneover, the amowats of state scientifle scholarship.

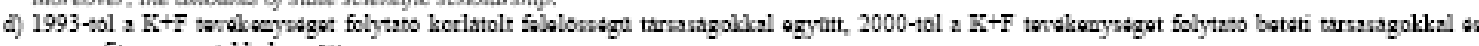
nouprofit szarvaze:akkol ezyent

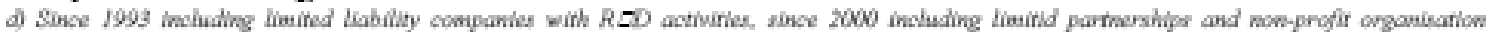
daaling with RAD activines

9) Amostizacio mallstili viltozas.

e) Change of costs without amovtizotions

Source: Hungarian Central Statistical Office, Research and Development 2004 


\section{Appendix 5}

3. A kutatás-fejlesztés fóbb arányai Main ratio of the $R D D$

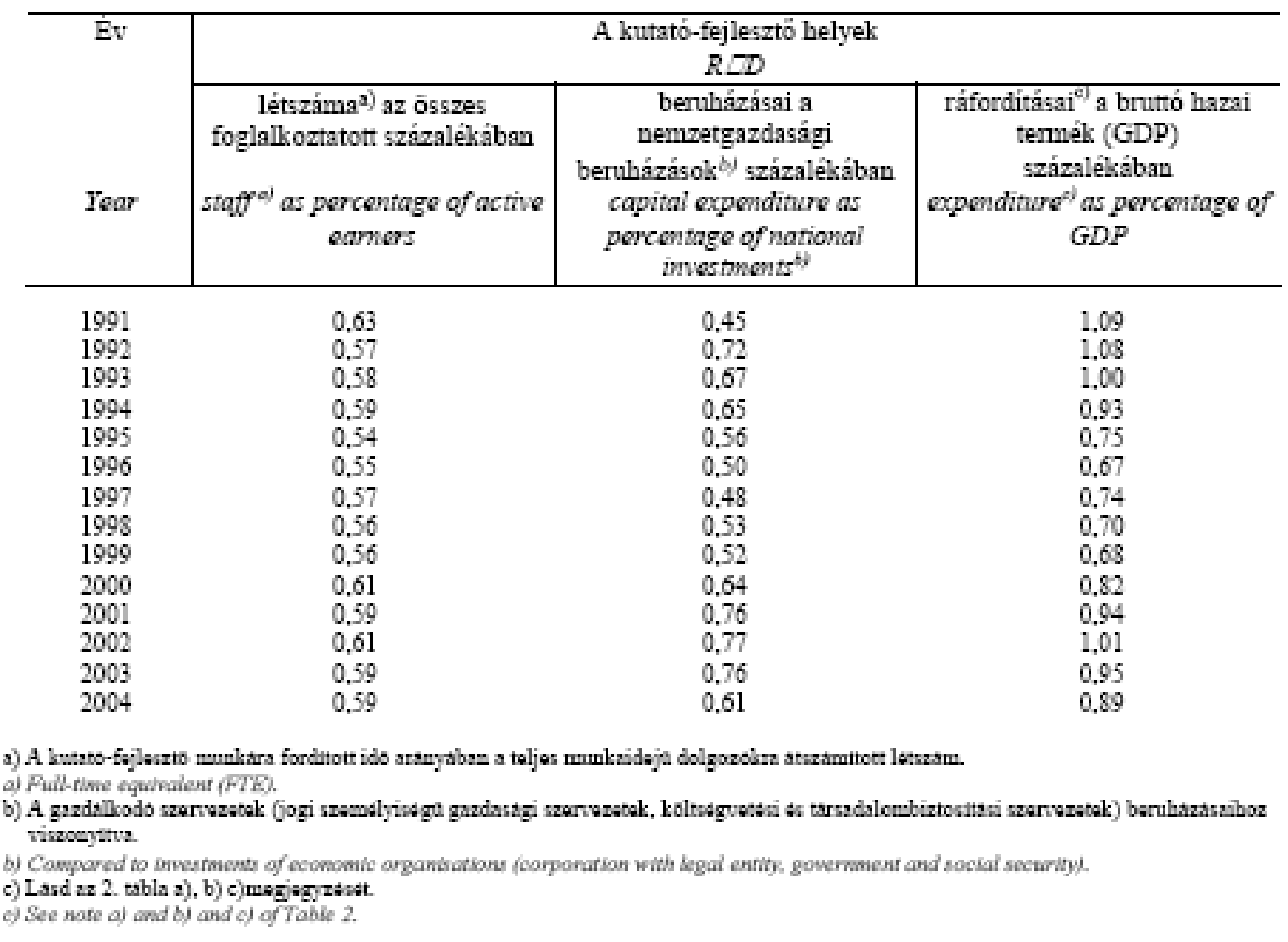

Source: Hungarian Central Statistical Office, Research and Development 2004 


\section{Appendix 6}

49. A vállallsozási szelktor lzutatói gazdasági ágalk szerint"

(teljes munlsaidejú dolgozólera átszámított létszám)

Researchers in business enterprises by indusiry

(Full-ime Equivalent FTE)

\begin{tabular}{|c|c|c|c|c|c|c|c|c|}
\hline $\begin{array}{c}\text { Szám- } \\
\text { jel } \\
\text { Code }\end{array}$ & $\begin{array}{l}\text { Gazdasági ág, ágazat } \\
\text { Industries, branches }\end{array}$ & 1998 & 1999 & 2000 & 2001 & 2002 & 2003 & 2004 \\
\hline$A, B$ & $\begin{array}{l}\text { Mezógazdaság, vadgazdálkodás, } \\
\text { balászat } \\
\text { Agricuiture, huonting and fishing }\end{array}$ & 109 & 65 & 62 & 71 & 99 & 108 & 95 \\
\hline$C$ & $\begin{array}{l}\text { Bányászat } \\
\text { Mining }\end{array}$ & - & ... & $\cdots$ & - & ... & 5 & $\ldots$ \\
\hline D & $\begin{array}{l}\text { Feldolgozóipar } \\
\text { Manufacturing }\end{array}$ & 2322 & 2367 & 2542 & 2651 & 2881 & 2932 & 2859 \\
\hline DA & $\begin{array}{l}\text { Ebböl-Of which: } \\
\text { élelmiszerek, italok és } \\
\text { dohánytermékek } \\
\text { manufacture of food products, } \\
\text { beverages and tobacco products }\end{array}$ & 66 & 66 & 83 & 85 & 69 & 93 & 69 \\
\hline $\mathrm{DB}$ & $\begin{array}{l}\text { textiliák, ruházat, bòr- és } \\
\text { szörmetermékek } \\
\text { manufacture of textiles, wearing } \\
\text { apparel; dressing and dyeing of fur }\end{array}$ & 23 & 16 & 11 & 14 & 9 & 11 & 11 \\
\hline DF-DH & $\begin{array}{l}\text { vegyipar } \\
\text { chemical industry }\end{array}$ & 1146 & 1202 & 1146 & 1135 & 1267 & 1120 & 1270 \\
\hline DK-DM & $\begin{array}{l}\text { gépipar } \\
\text { manufacture of machinery and } \\
\text { equipment }\end{array}$ & 1037 & 1002 & 1214 & 1342 & 1446 & 1600 & 1425 \\
\hline $\mathrm{E}$ & $\begin{array}{l}\text { Villamosenergia-, gaz-, hó- és vizellátás } \\
\text { Electricity, gas, steam and water supply }\end{array}$ & 64 & 85 & 87 & 97 & 77 & 90 & 69 \\
\hline $\mathrm{F}$ & $\begin{array}{l}\text { Epitóipar } \\
\text { Construction }\end{array}$ & 12 & 8 & 20 & 12 & 14 & 14 & 13 \\
\hline$G-Q$ & $\begin{array}{l}\text { Szolgáltatási szektor } \\
\text { Service sector }\end{array}$ & 537 & 735 & 1189 & 1240 & 1270 & 1333 & 1270 \\
\hline G & $\begin{array}{l}\text { Ebböl-Of which: } \\
\text { kereskedelem, kōziti jármû és } \\
\text { közszülkségleti cikkek javitása, } \\
\text { karbantartása } \\
\text { wholesale and retaile trade; repair of } \\
\text { motor-vehicles, motorcycles and } \\
\text { personal and househoid goods }\end{array}$ & 19 & 42 & 399 & 379 & 404 & 460 & 416 \\
\hline I & $\begin{array}{l}\text { szállítás, raktározás, posta, távközlés } \\
\text { transport, storage and } \\
\text { communication }\end{array}$ & 226 & 260 & 193 & 173 & 147 & 68 & 63 \\
\hline 72 & $\begin{array}{l}\text { számitástechnika és ebhez } \\
\text { kapcsolódó tevékenységel } \\
\text { computer and related activities }\end{array}$ & 125 & 114 & 181 & 222 & 226 & 223 & 215 \\
\hline$A-Q$ & $\begin{array}{l}\text { Mindōsszesen } \\
\text { Total }\end{array}$ & 3044 & 3261 & 3901 & 4071 & 4344 & 4482 & 4309 \\
\hline
\end{tabular}

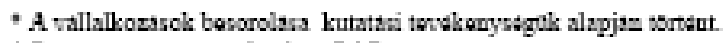

- Business enterprises by thezr Rob activity.

Source: Hungarian Central Statistical Office, Research and Development 2004 


\section{Appendix 7}

50. A vállallzozási szelctor lkutatás-fejlesztési ráforditásai gazdasági ágalk szerint" Business enterprise $R \square D$ expenditure by industry"

(millio $\mathrm{Ft}-$ million HUF)

\begin{tabular}{|c|c|c|c|c|c|c|c|c|}
\hline $\begin{array}{c}\text { Szám- } \\
\text { jel } \\
\text { Code }\end{array}$ & $\begin{array}{l}\text { Gazdasági ág, ágazat } \\
\text { Indistries, branches }\end{array}$ & 1998 & 1999 & 2000 & 2001 & 2002 & 2003 & 2004 \\
\hline$A, B$ & $\begin{array}{l}\text { Mezógazdaság, vadgazdálkodás, } \\
\text { halászat } \\
\text { Agricuiture, hunting and fishing }\end{array}$ & 1239,2 & 690,7 & 555,0 & 730,2 & 1268,6 & 1277,5 & 884,8 \\
\hline$C$ & $\begin{array}{l}\text { Bányászat } \\
\text { Mining }\end{array}$ & - & ... & $\ldots$ & - & $\ldots$ & 31,9 & $\ldots$ \\
\hline $\mathrm{D}$ & $\begin{array}{l}\text { Feldolgozóipar } \\
\text { Manufacturing }\end{array}$ & 22185,0 & 25718,4 & 36879,1 & 44233,9 & 45313,3 & 49700,5 & 60042,3 \\
\hline DA & $\begin{array}{l}\text { Ebböl - Of which: } \\
\text { élelmiszerek, italok és } \\
\text { dohánytermékek } \\
\text { manufacture of food products, } \\
\text { beverages and tobacco } \\
\text { products }\end{array}$ & 682,4 & 900,9 & 987,3 & 966,5 & 967,2 & 1236,9 & 909,5 \\
\hline $\mathrm{DB}$ & $\begin{array}{l}\text { textiliák, ruházat, bòr- és } \\
\text { szörmetermékek } \\
\text { manufacture of textiles, woaring } \\
\text { apparel; dressing and dyeing } \\
\text { offur }\end{array}$ & 136,3 & 103,4 & 39,1 & 139,8 & 96,5 & 153,5 & 61,8 \\
\hline $\mathrm{DF}-\mathrm{DH}$ & $\begin{array}{l}\text { vegyipar } \\
\text { chemical industry }\end{array}$ & 14696,4 & 17185,3 & 19699,8 & 25168,5 & 26092,7 & 25671,9 & 33122,3 \\
\hline $\mathrm{DK}-\mathrm{DM}$ & $\begin{array}{l}\text { gépipar } \\
\text { manufacture of machinery and } \\
\text { equipment }\end{array}$ & 6381,4 & 6979,9 & 15437,6 & 17019,1 & 15805,1 & 21166,3 & 24726,7 \\
\hline E & $\begin{array}{l}\text { Villamosenergia-, gáz-, bô- és } \\
\text { vizellátás } \\
\text { Electricity, gas, steam and water } \\
\text { supply }\end{array}$ & 315,6 & 339,9 & 406,2 & 388,6 & 448,5 & 469,6 & 423,3 \\
\hline F & $\begin{array}{l}\text { Epitóipar } \\
\text { Construction }\end{array}$ & 25,3 & 39,9 & 53,2 & 73,8 & 128,5 & 157,7 & 169,1 \\
\hline $\mathrm{G}-\mathrm{Q}$ & $\begin{array}{l}\text { Szolgáltatási szektor } \\
\text { Service sector } \\
\text { Ebböl-Of which: }\end{array}$ & 2615,2 & 4658,3 & 8809,0 & 10946,3 & 13651,1 & 12928,4 & 13106,2 \\
\hline G & $\begin{array}{l}\text { kereskedelem, kōzúti jármú és } \\
\text { közszùlkségleti cikkek javitása, } \\
\text { karbantartása } \\
\text { wholesale, retaile trade; repair } \\
\text { of motor-vehicles, motorcycles } \\
\text { and personal and household } \\
\text { goods }\end{array}$ & 137,8 & 386,7 & 3794,4 & 4801,2 & 6752,8 & 6885,7 & 6986,3 \\
\hline I & $\begin{array}{l}\text { szállítás, raktározás, posta, } \\
\text { távközlés } \\
\text { transport, storage and } \\
\text { communication }\end{array}$ & 707,6 & 1432,5 & 1524,5 & 1947,3 & 650,4 & 588,4 & 398,3 \\
\hline 72 & $\begin{array}{l}\text { számitástechnika és elhez } \\
\text { kapcsolódó tevékenységek } \\
\text { computer and rolatod activities }\end{array}$ & 707,4 & 639,1 & 1228,5 & 1506,0 & 5293,5 & 1450,0 & 1690,5 \\
\hline$A-Q$ & $\begin{array}{l}\text { Mindōsszesen } \\
\text { Total expenditure }\end{array}$ & 26380,3 & 31458,2 & 46703,5 & 56372,8 & 60827,9 & 64565,6 & 74641,4 \\
\hline
\end{tabular}

Source: Hungarian Central Statistical Office, Research and Development 2004 


\section{Appendix 8}

1. A kutató-fejlesztô helyeli száma szelctorok és gazdasági ágal szerint Number of R\&D unirs by sector and induseries

\begin{tabular}{|c|c|c|c|c|c|}
\hline \multirow[t]{3}{*}{$\begin{array}{l}\text { Szam- } \\
\text { jel }\end{array}$} & \multirow{3}{*}{$\begin{array}{l}\text { Gazdasagi og. } \\
\text { agnzat } \\
\text { Industries, branch }\end{array}$} & $\begin{array}{c}\text { Rutoto-fejleszto } \\
\text { intezet es egyeb } \\
\text { bututohely }\end{array}$ & $\begin{array}{l}\text { Felsóolstatisti } \\
\text { butatohely }\end{array}$ & $\begin{array}{c}\text { Vallalkozasi } \\
\text { kutató-Sejlesz:0 } \\
\text { hely }\end{array}$ & \multirow{3}{*}{$\begin{array}{l}\text { Osszeser } \\
\text { Total }\end{array}$} \\
\hline & & \multicolumn{3}{|c|}{ szama - number of } & \\
\hline & & $\begin{array}{c}\text { R\&D institute and } \\
\text { other research } \\
\text { whit }\end{array}$ & $\begin{array}{l}\text { RGLD unit } \\
\text { of higher } \\
\text { education }\end{array}$ & $\begin{array}{l}R \& D \text { unit of } \\
\text { enterprise }\end{array}$ & \\
\hline A & $\begin{array}{l}\text { Mezógazdasag, vad-erdógnzdalkodas } \\
\text { Agriculure, hunting and forespy }\end{array}$ & 2 & - & 37 & 39 \\
\hline B & $\begin{array}{l}\text { Halgnzdalkodas } \\
\text { Fishing }\end{array}$ & - & - & 5 & 5 \\
\hline c & $\begin{array}{l}\text { Bunyaszat } \\
\text { Mining }\end{array}$ & - & - & $\ldots$ & $\cdots$ \\
\hline D & $\begin{array}{l}\text { Feldolgozoipar } \\
\text { Mamuftochring } \\
\text { ebbol - of which: }\end{array}$ & - & - & 276 & 276 \\
\hline 15 & $\begin{array}{l}\text { elelmiszer, inal gyartisa } \\
\text { mamigfacture of food products and } \\
\text { beverages }\end{array}$ & - & - & 31 & 31 \\
\hline 24 & $\begin{array}{l}\text { vegyi anyag, ternek gyartasa } \\
\text { mamufacture of chomicals and } \\
\text { chemical products }\end{array}$ & - & - & 55 & 55 \\
\hline 29 & $\begin{array}{l}\text { gep, berendezés gyartisa } \\
\text { manufacture of machinery and equipment }\end{array}$ & - & - & 43 & 43 \\
\hline 31 & $\begin{array}{l}\text { villomos gep es kesrilek gyctisa } \\
\text { manufacrire of electrical madinery and } \\
\text { aoparanis }\end{array}$ & - & - & 20 & 20 \\
\hline 33 & $\begin{array}{l}\text { muiszergyartis } \\
\text { manufacare of modical, precision and } \\
\text { optical instruments, warches and clocks }\end{array}$ & - & - & 40 & 40 \\
\hline B & $\begin{array}{l}\text { Villamosenergin-giz-, goz-es vizellates } \\
\text { Electricio, gas and water sugphy }\end{array}$ & - & - & 8 & 8 \\
\hline F & $\begin{array}{l}\text { Epitoipar } \\
\text { Construction }\end{array}$ & - & - & 4 & 4 \\
\hline G & $\begin{array}{l}\text { Kereskedelem, javitas } \\
\text { Whoiesale and retail trade, repair of motor }\end{array}$ & - & - & 23 & 23 \\
\hline I & Szallitás, ralstarozass, posta, tavkózlés & - & - & 4 & 4 \\
\hline $\mathrm{K}$ & $\begin{array}{l}\text { Ingatlauugyletek, gazdasigi szolgaltatas } \\
\text { Real estate renting and burinesz actritios } \\
\text { ebbobl - of which: }\end{array}$ & 85 & 20 & 286 & 391 \\
\hline 73 & $\begin{array}{l}\text { kutatas-fejlesztes } \\
\text { research and denejopment }\end{array}$ & 79 & 20 & 199 & 298 \\
\hline L & $\begin{array}{l}\text { Közigazgatas, védelem bötelezô } \\
\text { tirsadalombiztositss } \\
\text { Public aḋimisistration and defonc, } \\
\text { compwlsory social socirin }\end{array}$ & 11 & - & - & 11 \\
\hline M & $\begin{array}{l}\text { Oktutas } \\
\text { Eduction }\end{array}$ & 4 & 1647 & $\ldots$ & 1652 \\
\hline $\mathrm{N}$ & $\begin{array}{l}\text { Egészségügyi, szocialls ellatis } \\
\text { Hoalth and social work }\end{array}$ & 15 & & 7 & 22 \\
\hline 0 & $\begin{array}{l}\text { Egyeb közóssegi, személyi szolgaltatas } \\
\text { Other commintiny, social and personal' sevice } \\
\text { actrvities }\end{array}$ & 58 & 30 & 15 & 103 \\
\hline & Mindösszesen - Total & 175 & 1697 & 669 & 2541 \\
\hline
\end{tabular}

Source: Hungarian Central Statistical Office, Research and Development 2004 


\section{Appendix 9}

2. A lzutatö-fejlesztô helyelken foglallioztatottals létszíma gazdasági àgals szerint Staff number in $R \& D$ units by indistries

\begin{tabular}{|c|c|c|c|c|c|c|c|}
\hline \multirow{3}{*}{$\begin{array}{c}\text { Szám- } \\
\text { jel }\end{array}$} & \multirow{3}{*}{$\begin{array}{l}\text { Gozdasagl ag, } \\
\text { agazat }\end{array}$} & \multirow{2}{*}{$\begin{array}{l}\mathrm{K}+\mathrm{F} \\
\text { létszim } \\
\text { osszesen } \\
\end{array}$} & \multicolumn{2}{|c|}{ Ebbol - Of which: } & \multirow{2}{*}{$\begin{array}{l}\mathrm{K}+\mathrm{F} \\
\text { létszim } \\
\text { ósszesen } \\
\end{array}$} & \multicolumn{2}{|c|}{ Ebobol-Of which } \\
\hline & & & $\begin{array}{l}\text { a sutatók, } \\
\text { fejlesztók }\end{array}$ & \begin{tabular}{|c|} 
seged- \\
személyzet
\end{tabular} & & $\begin{array}{l}\text { a kutatok, } \\
\text { fejlesztok }\end{array}$ & $\begin{array}{c}\text { seged- } \\
\text { szemelyzet }\end{array}$ \\
\hline & & \multicolumn{3}{|c|}{ tényleges létszama (fo) } & \multicolumn{3}{|c|}{$\begin{array}{l}\text { teljes numpkaidejú dolgozókra } \\
\text { atszamitot létszama (fo) }\end{array}$} \\
\hline \multirow[t]{2}{*}{ Cade } & \multirow[t]{2}{*}{ Industries, branch } & $\begin{array}{l}\text { Total } \\
\text { R\&D }\end{array}$ & $\begin{array}{l}\text { scientists } \\
\text { and } \\
\text { engineers }\end{array}$ & technicians & $\begin{array}{l}\text { Total } \\
\text { R\&D }\end{array}$ & $\begin{array}{l}\text { scientists } \\
\text { and } \\
\text { ongineers. }\end{array}$ & Techicians \\
\hline & & \multicolumn{3}{|c|}{ staff number (person) } & \multicolumn{3}{|c|}{ calcutanad stafof number (FTE) (parson) } \\
\hline$A$ & $\begin{array}{l}\text { Mezogazdasig, vad-erdogazdilliodas } \\
\text { Arriculture, hurting and torestry }\end{array}$ & 269 & 117 & 65 & 178 & 83 & 48 \\
\hline B & $\begin{array}{l}\text { Halgazdilkodhs } \\
\text { Fishing }\end{array}$ & 42 & 11 & 23 & 32 & 6 & 11 \\
\hline c & $\begin{array}{l}\text { Bányaisat } \\
\text { Aining }\end{array}$ & $\cdots$ & + & $\cdots$ & $\cdots$ & +. & $\cdots$ \\
\hline D & $\begin{array}{l}\text { Feldoigozoipar } \\
\text { Monaffocturing } \\
\text { ebbol- of which }\end{array}$ & 5462 & 3267 & 1604 & 4175 & 2610 & 1150 \\
\hline 15 & $\begin{array}{l}\text { éleiniszer, ital gyartasa } \\
\text { manajacture of food products and } \\
\text { beverages. }\end{array}$ & 350 & 93 & 97 & 217 & 65 & 45 \\
\hline 24 & $\begin{array}{l}\text { vegyi asyag, temsek gyanasa } \\
\text { manafacture of chemicais and } \\
\text { chenical producst }\end{array}$ & 2238 & 1144 & 933 & 1960 & 1038 & 789 \\
\hline 29 & $\begin{array}{l}\text { gep, berendezes gyairtasa } \\
\text { manafacture of machinery and } \\
\text { ognuipment }\end{array}$ & 486 & 308 & 115 & 382 & 256 & 81 \\
\hline 31 & $\begin{array}{l}\text { villamos gè è keizzilek gyantasa } \\
\text { manufacture of clectrical } \\
\text { machinery and apparatus }\end{array}$ & 635 & 512 & 96 & 333 & 268 & 45 \\
\hline 33 & $\begin{array}{l}\text { múszergyartis } \\
\text { mamafacture of modical, precision } \\
\text { and oprical instruments, watcies } \\
\text { and ciocess }\end{array}$ & 322 & 219 & 64 & 261 & 190 & 46 \\
\hline E & $\begin{array}{l}\text { Villamosenergia-, gaz-, gòz-és } \\
\text { vizellátas } \\
\text { Elactricioy, gas and ware supply }\end{array}$ & 78 & 44 & 22 & 38 & 21 & 12 \\
\hline F & $\begin{array}{l}\text { Epitöipar } \\
\text { Construction }\end{array}$ & 37 & 18 & 6 & 14 & 9 & 3 \\
\hline G & $\begin{array}{l}\text { Rereskedelem, javitis } \\
\text { Wholesale and retail trade, repair of } \\
\text { motor whicles, and housohold goods }\end{array}$ & 548 & 471 & 25 & 480 & 416 & 17 \\
\hline I & $\begin{array}{l}\text { Szallitis, raktirozas, posta, tavkoòzles } \\
\text { Transport, storage and communication }\end{array}$ & 155 & 135 & 11 & 73 & 63 & 5 \\
\hline $\mathrm{K}$ & $\begin{array}{l}\text { Ingatianigyletek, gazdasagi szolgáltatís } \\
\text { Roul estate renting and business } \\
\text { activities } \\
\text { ebbôl - of which: }\end{array}$ & 9816 & 5532 & 2080 & 7534 & 4722 & 1670 \\
\hline 73 & $\begin{array}{l}\text { kutatis-fejlesztés } \\
\text { reseurch and developmont }\end{array}$ & 8864 & 4952 & 1898 & 6922 & 4328 & 1581 \\
\hline I & $\begin{array}{l}\text { Közigazgatas, védelem, kōtelezó } \\
\text { tursadalombiztositas } \\
\text { Public administration and defence, } \\
\text { compulsony social securioy }\end{array}$ & 228 & 136 & 35 & 128 & 109 & 6 \\
\hline M & $\begin{array}{l}\text { Obtati: } \\
\text { Edication }\end{array}$ & 28849 & 18718 & 4101 & 8493 & 5876 & 1311 \\
\hline $\mathrm{N}$ & $\begin{array}{l}\text { Egészségugyt, szociallis ellatas } \\
\text { Heaith and social work }\end{array}$ & 1448 & 585 & 451 & $\$ 92$ & 463 & 343 \\
\hline 0 & $\begin{array}{l}\text { Egyeb hózössegi, szemelyi szolgaltatas } \\
\text { Other comminipy, social and personal } \\
\text { senvice activities }\end{array}$ & 2655 & 1364 & 445 & 775 & 506 & 134 \\
\hline & Mindösszesen - Totat & 49615 & 30420 & 8873 & 22826 & 14904 & 4713 \\
\hline
\end{tabular}

Source: Hungarian Central Statistical Office, Research and Development 2004 


\section{Appendix 10}

\section{A kutató-fejlesztó helyelk ráfordításai gazdasági ágalk szerint} Expenditure of R\&D units by industries

(millio Ft - million HUF)

\begin{tabular}{|c|c|c|c|c|}
\hline \multirow[b]{2}{*}{$\begin{array}{l}\text { Szim- } \\
\text { jel } \\
\text { Code }\end{array}$} & \multirow[b]{2}{*}{$\begin{array}{l}\text { Gazdasagi àg, } \\
\text { dgazat } \\
\text { Industries, branch }\end{array}$} & \multirow[b]{2}{*}{$\begin{array}{l}\text { Ráforditis } \\
\text { Expenditure }\end{array}$} & \multicolumn{2}{|c|}{ Ebból-Of which: } \\
\hline & & & $\begin{array}{c}\mathrm{K}+\mathrm{F} \\
\text { költség } \\
\text { current } \\
\text { expendinure } \\
\end{array}$ & $\begin{array}{l}\text { beruházas } \\
\text { capital expenaiture }\end{array}$ \\
\hline$A$ & $\begin{array}{l}\text { Mezögnzdasig, vad-erdoggazdilkodas } \\
\text { Agriculture, huwting and forestry }\end{array}$ & 887,8 & 808,3 & 79,5 \\
\hline B & $\begin{array}{l}\text { Halgazdilkodhs } \\
\text { Fishing }\end{array}$ & 31,0 & 29,2 & 18,2 \\
\hline C & $\begin{array}{l}\text { Binyiszat } \\
\text { Moning }\end{array}$ & & --. & -.- \\
\hline $\mathrm{D}$ & $\begin{array}{l}\text { Feldolgozo:par } \\
\text { Manuffacturing } \\
\text { ebboil - of which }\end{array}$ & 55344,8 & 41040,9 & 14303,9 \\
\hline 15 & $\begin{array}{l}\text { élelmiszer, ital gyarthisa } \\
\text { manyfacture of food products and } \\
\text { benerages }\end{array}$ & 720,1 & 599,2 & 120,9 \\
\hline 24 & $\begin{array}{l}\text { vegyi amyag, temék gyártisa } \\
\text { manufacture of chemicals and } \\
\text { chemical products }\end{array}$ & 27090,4 & 21141,7 & 5948,6 \\
\hline 29 & $\begin{array}{l}\text { gep, bereedezes gyaitass } \\
\text { manyfocture of machinery and } \\
\text { oguipment }\end{array}$ & 3364,6 & 2275,4 & 1089,1 \\
\hline 31 & $\begin{array}{l}\text { villamos gép és készilélk gyartása } \\
\text { manyfocture of electrical machinary } \\
\text { and apparatus }\end{array}$ & 8117,3 & 4489,8 & 3627,5 \\
\hline 33 & $\begin{array}{l}\text { múszergyartas } \\
\text { manufacture of medical, precision and } \\
\text { optical instriments, watches and } \\
\text { clocks }\end{array}$ & 1115,5 & 1038,5 & 77,0 \\
\hline E & $\begin{array}{l}\text { Vilamosenergia-, gaz-, góz-és vizellatás } \\
\text { Elactricity, ges and water rupply }\end{array}$ & 234,5 & 93,3 & 141,2 \\
\hline F & $\begin{array}{l}\text { Epitöipar } \\
\text { Construction }\end{array}$ & 163,4 & 110,1 & 53,3 \\
\hline G & $\begin{array}{l}\text { Kereskedelem, javitis } \\
\text { Wholesale and retail trade, repair of motor } \\
\text { wehicles, and housohold goods }\end{array}$ & 6986,3 & 6680,1 & 306,2 \\
\hline I & $\begin{array}{l}\text { Szillitís, raktározas, posta, tavkōzlés } \\
\text { Transport, storage and communication }\end{array}$ & 398,3 & 336,5 & 61,8 \\
\hline $\mathbb{K}$ & $\begin{array}{l}\text { Ingatinuigyletek, gazdasagi szolgaltatás } \\
\text { Roal estate renting and business activities } \\
\text { ebböl - of which: }\end{array}$ & 50388,3 & 46111,5 & 4276,8 \\
\hline 73 & $\begin{array}{l}\text { kutatas-fejlesztés } \\
\text { resourch and denelopment }\end{array}$ & 47451,7 & 43479,9 & 3971,8 \\
\hline L & $\begin{array}{l}\text { Kózigazgatís, védelem, kötelezó } \\
\text { társadalombiztositís } \\
\text { Public adiministration and defonce, } \\
\text { comoulsony social securiot }\end{array}$ & 5969,5 & 4966,9 & 1002,5 \\
\hline M & $\begin{array}{l}\text { Oltatis } \\
\text { Education }\end{array}$ & 44523,2 & 40312,8 & 4210,4 \\
\hline $\mathrm{N}$ & $\begin{array}{l}\text { Egészégugyyi, szociális ellatis } \\
\text { Heaith and social work }\end{array}$ & 2922,7 & 2588,8 & 333,9 \\
\hline 0 & $\begin{array}{l}\text { Egyéb kōzösségi, személyi szolgáltatís } \\
\text { Other community, social and personal } \\
\text { senvice activities }\end{array}$ & 4860,5 & 4451,8 & 408,7 \\
\hline & $\begin{array}{l}\text { Gazdasági ág szerint nem besorolhato } \\
\text { Not classiffable by indiustry }\end{array}$ & 8629,4 & - & - \\
\hline & $\begin{array}{l}\text { Mindösszesen } \\
\text { Total }\end{array}$ & 181525,4 & 147708,2 & 25187,8 \\
\hline
\end{tabular}

Source: Hungarian Central Statistical Office, Research and Development 2004 
69

Appendix 11: BERD by sectors, 3-digit level, 2001-2004 (000 HUF)

\begin{tabular}{|c|c|c|c|c|}
\hline NACE code & 2001 & 2002 & 2003 & 2004 \\
\hline 011 & 441494 & 736369 & 687898 & 460714 \\
\hline 014 & 80818 & 51094 & 76697 & 48409 \\
\hline 020 & 62714 & 68546 & : & 36108 \\
\hline 050 & : & 87027 & 75965 & 31002 \\
\hline 151 & 70961 & 131522 & 147180 & 85530 \\
\hline 153 & 34471 & 65947 & 77325 & 31316 \\
\hline 156 & 14807 & 45381 & 81000 & 110106 \\
\hline 157 & 47272 & 30112 & 36902 & : \\
\hline 158 & 29579 & 149139 & 171366 & 86926 \\
\hline 159 & : & 59606 & 42158 & 104877 \\
\hline 241 & 871968 & 814307 & 777780 & 776697 \\
\hline 243 & 176636 & : & 823111 & 146173 \\
\hline 244 & 14947762 & 17286023 & 17839945 & 25655644 \\
\hline 245 & 163783 & 53182 & 35081 & 177539 \\
\hline 246 & 78946 & 56282 & 51815 & 24036 \\
\hline 251 & 228140 & : & 239576 & 165473 \\
\hline 252 & 363000 & 130608 & 260401 & 254636 \\
\hline 281 & 46456 & 60425 & 41658 & 14645 \\
\hline 282 & 13947 & : & 69730 & : \\
\hline 291 & 103037 & 45099 & 82617 & 72435 \\
\hline 292 & 241695 & 303907 & 510713 & 747075 \\
\hline 293 & 221227 & 199877 & 275723 & 217537 \\
\hline 294 & : & 231967 & 203949 & 1088945 \\
\hline 295 & 90400 & 123173 & 137208 & 95551 \\
\hline 297 & 934461 & 871512 & 776115 & 1115881 \\
\hline 300 & 198398 & 260328 & : & : \\
\hline 312 & 350156 & 282606 & 241340 & 352491 \\
\hline 315 & 3200627 & 2488065 & 2889785 & 3001107 \\
\hline 316 & 567978 & 416243 & 1645404 & 3543586 \\
\hline 321 & 274978 & 501372 & 65262 & 308799 \\
\hline 322 & 4709523 & 5301557 & 5339582 & 4888519 \\
\hline 323 & : & 25189 & 390911 & 544702 \\
\hline 331 & 272814 & 490866 & 550169 & 228983 \\
\hline 332 & 336977 & 356006 & 489349 & 497143 \\
\hline 333 & 140000 & 169311 & 179418 & 381389 \\
\hline 341 & 3076905 & 944181 & 1272561 & 3379996 \\
\hline 343 & 1573872 & 1722505 & 4253237 & 2301585 \\
\hline 361 & : & 39667 & 21787 & 13005 \\
\hline 402 & 29921 & : & 36240 & : \\
\hline 410 & 76498 & 167997 & 150407 & 158574 \\
\hline 452 & 69989 & 112926 & 143117 & 163408 \\
\hline 511 & 58198 & 62461 & 103623 & 37956 \\
\hline 514 & 211155 & 146937 & 169780 & : \\
\hline 515 & : & 190782 & 63182 & 36181 \\
\hline 516 & 188021 & 366310 & : & : \\
\hline 517 & 4213932 & 5943675 & : & : \\
\hline 518 & : & : & 327457 & 270100 \\
\hline 519 & : & : & 6182165 & 6446917 \\
\hline 642 & 1635391 & 414552 & 414562 & 283396 \\
\hline 722 & 1122109 & 426727 & 516003 & 960918 \\
\hline 726 & 122588 & 184041 & 142551 & 42790 \\
\hline 731 & 9886286 & 10385255 & 8568453 & 7073346 \\
\hline 732 & 340236 & 764918 & 370878 & 478122 \\
\hline 741 & 159798 & 225232 & 268758 & 296490 \\
\hline 742 & 434648 & 403663 & 1131945 & 308639 \\
\hline 743 & 164356 & 457212 & 540925 & 657217 \\
\hline 748 & 14378 & 10935 & : & 44775 \\
\hline 851 & : & 41391 & 86760 & 338005 \\
\hline 900 & 195860 & 148090 & 170983 & 58087 \\
\hline 913 & 11702 & 34407 & : & 56364 \\
\hline
\end{tabular}

Source: CSO, data provide exclusively for this project, free of charge 


\section{Appendix 12}

2. Distribution of innovation by industries and branches

\begin{tabular}{|c|c|c|c}
\hline Innovativ & Nem & Mind- & (Százalék - Per cent) \\
vállalko- & innovativ & összesen & Industries, branches \\
zások & vállalko- & & \\
összesen & zások & \\
összesen & & \\
Innovative & Non & Total & \\
enterprises & innovative & & \\
& & \\
\hline
\end{tabular}

\begin{tabular}{|c|c|c|c|}
\hline 13,1 & 86,9 & 100,0 & Mining and quarrying \\
\hline 27,9 & 72,1 & 100,0 & Manufacture of food products and beverages \\
\hline 8,0 & 92,0 & 100,0 & Manufacture of textiles and textile products \\
\hline 4,5 & 95,5 & 100,0 & Manufacture of leather and leather products \\
\hline 11,8 & 88,2 & 100,0 & Manufacture of wood and wood products \\
\hline 14,7 & 85,3 & 100,0 & $\begin{array}{l}\text { Manufacture of pulp, paper and paper products, } \\
\text { publishing and printing }\end{array}$ \\
\hline- & 100,0 & 100,0 & $\begin{array}{l}\text { Manufacture of coke, refined petroleum products and } \\
\text { nuclear fuel }\end{array}$ \\
\hline 45,0 & 55,0 & 100,0 & $\begin{array}{l}\text { Manufacture of chemicals, chemical products and man- } \\
\text { made fibres }\end{array}$ \\
\hline 22,8 & 77,2 & 100,0 & Manufacture of rubber and plastic products \\
\hline 15,7 & 84,3 & 100,0 & Manufacture of other non-metallic mineral products \\
\hline 19,4 & 80,6 & 100,0 & $\begin{array}{l}\text { Manufacture of basic metals and fabricated metal } \\
\text { products }\end{array}$ \\
\hline 33,2 & 66,8 & 100,0 & Manufacture of machinery and equipment n.e.c. \\
\hline 30,3 & 69,7 & 100,0 & Manufacture of electrical and optical equipment \\
\hline 29,6 & 70,4 & 100,0 & Manufacture of transport equipment \\
\hline 30,4 & 69,6 & 100,0 & Manufacturing N.E.C. \\
\hline 21,7 & 78,3 & 100,0 & Manufacturing total \\
\hline 14,3 & 85,7 & 100,0 & Electricity, gas and water supply \\
\hline 21,4 & 78,6 & 100,0 & Industry total \\
\hline 13,7 & 86,3 & 100,0 & Wholesale \\
\hline 5,6 & 94,4 & 100,0 & Transport, storage and communication \\
\hline 23,3 & 76,7 & 100,0 & Financial intermediation \\
\hline 33,3 & 66,7 & 100,0 & $\begin{array}{l}\text { Computer and related activities, Research and } \\
\text { development, Architectural and engineering } \\
\text { activities }\end{array}$ \\
\hline 15,8 & 84,2 & 100,0 & Service total \\
\hline 19,4 & 80,6 & 100,0 & Total \\
\hline
\end{tabular}

Source: Innováció 2003/ Innovation 2003, CSO 


\section{Appendix 13}

8. A vállalkozások árbevételének megoszlása a termék újdonsága és létszám-kategóriák szerint Distribution of sales revenues of enterprises by novelty of product and staff categories

\begin{tabular}{c|c|c|c|c}
\hline \multicolumn{3}{|c}{ (Százalék - Per cent) } \\
Megnevezés & $\begin{array}{c}11-49 \\
\text { fös }\end{array}$ & $\begin{array}{c}50-249 \\
\text { fós }\end{array}$ & $\begin{array}{c}250 \text { fó és a } \\
\text { feletti } \\
\text { fós }\end{array}$ & Összesen \\
Denomination & $\begin{array}{c}11-49 \\
\text { employees }\end{array}$ & $\begin{array}{c}50-249 \\
\text { employees }\end{array}$ & 250 and more & Total \\
\hline
\end{tabular}

Árbevétel megoszlása

\begin{tabular}{|c|c|c|c|}
\hline $\begin{array}{l}\text { Csak a cégnél új termék } \\
\text { Product only new for given } \\
\text { enterprise }\end{array}$ & 2,4 & 1,4 & 5,6 \\
\hline A piacon is új termék & 1,0 & 0,7 & 2,1 \\
\hline \multicolumn{4}{|c|}{ Product new for the market itself } \\
\hline $\begin{array}{l}\text { Változatlan, régi termék } \\
\text { Unchanged, long-standing } \\
\text { product }\end{array}$ & 96,6 & 97,9 & 92,3 \\
\hline Összesen & 100,0 & 100,0 & 100,0 \\
\hline
\end{tabular}

Total

Source: Innováció 2003/ Innovation 2003, CSO 